Cochrane Database of Systematic Reviews

\title{
Computer-generated reminders delivered on paper to healthcare professionals: effects on professional practice and healthcare outcomes (Review)
}

Arditi C, Rège-Walther M, Durieux P, Burnand B

Arditi C, Rège-Walther $M$, Durieux $P$, Burnand $B$.

Computer-generated reminders delivered on paper to healthcare professionals: effects on professional practice and healthcare outcomes.

Cochrane Database of Systematic Reviews 2017, Issue 7. Art. No.: CD001175.

DOI: 10.1002/14651858.CD001175.pub4.

www.cochranelibrary.com

Computer-generated reminders delivered on paper to healthcare professionals: effects on professional practice and healthcare outcomes (Review) 
HEADER 1

ABSTRACT

PLAIN LANGUAGE SUMMARY

SUMMARY OF FINDINGS

BACKGROUND

OBJECTIVES

METHODS

RESULTS

Figure 1.

Figure 2.

Figure 3.

Figure 4.

Figure 5.

Figure 6.

DISCUSSION

AUTHORS' CONCLUSIONS

ACKNOWLEDGEMENTS

REFERENCES

CHARACTERISTICS OF STUDIES

ADDITIONAL TABLES

APPENDICES

WHAT'S NEW

HISTORY

CONTRIBUTIONS OF AUTHORS

DECLARATIONS OF INTEREST

SOURCES OF SUPPORT

DIFFERENCES BETWEEN PROTOCOL AND REVIEW

INDEX TERMS

\section{TABLE OF CONTENTS}

1

2

4

7

8

8

11

11

15

16

18

19

20

21

23

23

24 
[Intervention Review]

\section{Computer-generated reminders delivered on paper to healthcare professionals: effects on professional practice and healthcare outcomes}

Chantal Arditi ${ }^{1}$, Myriam Rège-Walther ${ }^{2}$, Pierre Durieux ${ }^{3}$, Bernard Burnand ${ }^{1}$

${ }^{1}$ Cochrane Switzerland, Institute of Social and Preventive Medicine, Lausanne University Hospital, Lausanne, Switzerland. 2Institute of Social and Preventive Medicine, Lausanne University Hospital, Lausanne, Switzerland. ${ }^{3}$ Department of Public Health and Medical Informatics, Georges Pompidou European Hospital, Paris, France

Contact address: Chantal Arditi, Cochrane Switzerland, Institute of Social and Preventive Medicine, Lausanne University Hospital, Lausanne, CH-1005, Switzerland. chantal.arditi@chuv.ch.

Editorial group: Cochrane Effective Practice and Organisation of Care Group.

Publication status and date: New search for studies and content updated (no change to conclusions), published in Issue 7, 2017.

Citation: Arditi C, Rège-Walther M, Durieux P, Burnand B. Computer-generated reminders delivered on paper to healthcare professionals: effects on professional practice and healthcare outcomes. Cochrane Database of Systematic Reviews 2017, Issue 7. Art. No.: CD001175. DOI: 10.1002/14651858.CD001175.pub4.

Copyright @ 2017 The Cochrane Collaboration. Published by John Wiley \& Sons, Ltd.

\section{A B S T R A C T}

\section{Background}

Clinical practice does not always reflect best practice and evidence, partly because of unconscious acts of omission, information overload, or inaccessible information. Reminders may help clinicians overcome these problems by prompting them to recall information that they already know or would be expected to know and by providing information or guidance in a more accessible and relevant format, at a particularly appropriate time. This is an update of a previously published review.

\section{Objectives}

To evaluate the effects of reminders automatically generated through a computerized system (computer-generated) and delivered on paper to healthcare professionals on quality of care (outcomes related to healthcare professionals' practice) and patient outcomes (outcomes related to patients' health condition).

\section{Search methods}

We searched CENTRAL, MEDLINE, Embase, six other databases and two trials registers up to 21 September 2016 together with reference checking, citation searching and contact with study authors to identify additional studies.

\section{Selection criteria}

We included individual- or cluster-randomized and non-randomized trials that evaluated the impact of computer-generated reminders delivered on paper to healthcare professionals, alone (single-component intervention) or in addition to one or more co-interventions (multi-component intervention), compared with usual care or the co-intervention(s) without the reminder component.

\section{Data collection and analysis}

Review authors working in pairs independently screened studies for eligibility and abstracted data. For each study, we extracted the primary outcome when it was defined or calculated the median effect size across all reported outcomes. We then calculated the median improvement and interquartile range (IQR) across included studies using the primary outcome or median outcome as representative outcome. We assessed the certainty of the evidence according to the GRADE approach. 


\section{Main results}

We identified 35 studies (30 randomized trials and five non-randomized trials) and analyzed 34 studies (40 comparisons). Twenty-nine studies took place in the USA and six studies took place in Canada, France, Israel, and Kenya. All studies except two took place in outpatient care. Reminders were aimed at enhancing compliance with preventive guidelines (e.g. cancer screening tests, vaccination) in half the studies and at enhancing compliance with disease management guidelines for acute or chronic conditions (e.g. annual followups, laboratory tests, medication adjustment, counseling) in the other half.

Computer-generated reminders delivered on paper to healthcare professionals, alone or in addition to co-intervention(s), probably improves quality of care slightly compared with usual care or the co-intervention(s) without the reminder component (median improvement $6.8 \%$ (IQR: $3.8 \%$ to $17.5 \%$ ); 34 studies (40 comparisons); moderate-certainty evidence).

Computer-generated reminders delivered on paper to healthcare professionals alone (single-component intervention) probably improves quality of care compared with usual care (median improvement 11.0\% (IQR 5.4\% to 20.0\%); 27 studies (27 comparisons); moderatecertainty evidence). Adding computer-generated reminders delivered on paper to healthcare professionals to one or more co-interventions (multi-component intervention) probably improves quality of care slightly compared with the co-intervention(s) without the reminder component (median improvement 4.0\% (IQR 3.0\% to 6.0\%); 11 studies (13 comparisons); moderate-certainty evidence).

We are uncertain whether reminders, alone or in addition to co-intervention(s), improve patient outcomes as the certainty of the evidence is very low ( $n=6$ studies (seven comparisons)). None of the included studies reported outcomes related to harms or adverse effects of the intervention.

\section{Authors' conclusions}

There is moderate-certainty evidence that computer-generated reminders delivered on paper to healthcare professionals probably slightly improves quality of care, in terms of compliance with preventive guidelines and compliance with disease management guidelines. It is uncertain whether reminders improve patient outcomes because the certainty of the evidence is very low. The heterogeneity of the reminder interventions included in this review also suggests that reminders can probably improve quality of care in various settings under various conditions.

\section{PLAIN LANGUAGE SUMMARY}

\section{The effect of automatically generated reminders delivered to providers on paper on quality of care and patient outcomes}

\section{What is the aim of this review?}

The aim of this Cochrane review was to find out if reminders, automatically generated through a computer, but delivered on paper to doctors help them provide the best recommended care. Cochrane researchers identified 35 studies and analyzed 34 of these studies to answer this question.

\section{Key messages}

Providing reminders to doctors probably improves slightly the quality of care patients receive. However, because the certainty of the evidence is moderate, more high-quality studies on the effectiveness of reminders are needed to confirm to findings of this review.

\section{What was studied in the review?}

Doctors do not always provide care that is recommended or that reflects the latest research, partly because of too much information or inaccessible information. Reminders may help doctors overcome these problems by reminding them about guidelines and research findings, or by providing advice, in a more accessible and relevant format, at a particularly appropriate time. For example, when a doctor sees a patient for an annual check-up, the doctor would receive the patient's chart with a reminder section listing the screening tests due that year, such as colorectal cancer screening. In this review, we evaluated the effects of reminders on the quality of care delivered by physicians, on patient outcomes, and on adverse effects. These reminders were automatically generated through a computer system but delivered on paper.

\section{What are the main results of the review?}

Twenty-nine studies were from the USA and six studies were from Canada, France, Israel and Kenya. The studies examined reminders to doctors to order screening tests, to provide vaccinations, to prescribe specific medications, or to discuss care with patients.

The review shows that:

- overall, reminders probably improve slightly quality of care by $6.8 \%$ (in 34 studies (40 comparisons), moderate-certainty evidence);

- reminders alone (single-component intervention) probably improve quality of care by $11.0 \%$ compared with usual care (in 27 studies ( 27 comparisons), moderate-certainty evidence); 
- adding reminders to one or more co-interventions (multi-component intervention) probably improve slightly quality of care by $4.0 \%$ compared with the co-intervention(s) without the reminder component (in 11 studies (13 comparisons), moderate-certainty evidence);

- it is uncertain whether reminders improve patient outcomes because the certainty of the evidence is very low;

- none of the included studies reported outcomes related to harms or adverse effects.

\section{How up to date is this review?}

The review authors searched for studies that had been published up to 21 September 2016. 


\section{SUMMARY OF FINDINGS}

\section{Summary of findings for the main comparison.}

Computer-generated reminders delivered on paper to healthcare professionals, alone or in addition to co-intervention(s), compared with usual care or the co-intervention(s) without the reminder component

\section{Patient or population: Healthcare professionals}

Settings: Outpatient care in Canada, France, Israel, Kenya and USA

Intervention: Reminders automatically generated through a computerized system (computer-generated) and delivered on paper to healthcare professionals, alone or in addition to one or more co-interventions, aimed at enhancing compliance with preventive guidelines (e.g. cancer screening tests, vaccination) or disease management guidelines for acute or chronic conditions (e.g. annual follow-ups, laboratory tests, medication adjustment, counseling)

Comparison: Usual care or co-intervention(s) without reminder component

\begin{tabular}{|c|c|c|c|c|}
\hline Outcomes & Median improvement & $\begin{array}{l}\text { Number of stud- } \\
\text { ies (compar- } \\
\text { isons) }\end{array}$ & $\begin{array}{l}\text { Certainty of the } \\
\text { evidence } \\
\text { (GRADE) }\end{array}$ & Comments \\
\hline Quality of care & $\begin{array}{l}\text { Pooling data across } \\
\text { the } 40 \text { comparisons, } \\
\text { the median improve- } \\
\text { ment in quality of care } \\
\text { associated with the re- } \\
\text { minder intervention } \\
\text { was } 6.8 \% \text { (IQR } 3.8 \% \text { to } \\
17.5 \% \text { ). }\end{array}$ & $\begin{array}{l}34 \text { studies } \\
\text { ( } 40 \text { comparisons) }\end{array}$ & $\begin{array}{l}\oplus \oplus \oplus \odot \\
\text { MODERATE } 1\end{array}$ & $\begin{array}{l}\text { Quality of care was measured by various } \\
\text { rates: e.g. test ordering rates, vaccination } \\
\text { rates, follow-up rates, prescription rates, } \\
\text { overall compliance rate. }\end{array}$ \\
\hline $\begin{array}{l}\text { Patient out- } \\
\text { comes }\end{array}$ & Not estimable & $\begin{array}{l}6 \text { studies } \\
\text { (7 comparisons) }\end{array}$ & $\begin{array}{l}\oplus \odot \odot \ominus \\
\text { VERY LOW } 2\end{array}$ & $\begin{array}{l}\text { No measurable effect on i) blood pressure, } \\
\text { glycated hemoglobin and cholesterol levels, } \\
\text { ii) reaching blood pressure, glycated hemo- } \\
\text { globin and cholesterol targets, and iii) mortal- } \\
\text { ity. }\end{array}$ \\
\hline Adverse effects & Not reported & - & - & $\begin{array}{l}\text { None of the included studies reported out- } \\
\text { comes related to harms or adverse effects of } \\
\text { reminders. }\end{array}$ \\
\hline
\end{tabular}

IQR: interquartile range

\section{GRADE Working Group grades of evidence}

High certainty: Further research is very unlikely to change our confidence in the estimate of effect.

Moderate certainty: Further research is likely to have an important impact on our confidence in the estimate of effect and may change the estimate.

Low certainty: Further research is very likely to have an important impact on our confidence in the estimate of effect and is likely to change the estimate.

Very low certainty: We are very uncertain about the estimate.

\footnotetext{
1 We downgraded the level of certainty of the evidence from high to moderate because of methodological limitations in the included studies and possible publication bias. We did not find other serious limitations in the other factors (indirectness of evidence, inconsistency of results, and imprecision of results).

2 We downgraded the level of certainty of the evidence from high to very low because of methodological limitations in the included studies, imprecision of results (wide confidence intervals) and inconsistency of the results.
} 


\section{Summary of findings 2.}

Computer-generated reminders delivered on paper to healthcare professionals alone (single-component intervention) compared with usual care

Patient or population: Healthcare professionals

Settings: Outpatient care in Canada, France, Israel, Kenya and USA

Intervention: Computer-generated reminders delivered on paper alone (single-component intervention)

Comparison: Usual care

\begin{tabular}{|c|c|c|c|c|}
\hline Outcomes & Median improvement & $\begin{array}{l}\text { Number of stud- } \\
\text { ies (compar- } \\
\text { isons) }\end{array}$ & $\begin{array}{l}\text { Certainty of the } \\
\text { evidence } \\
\text { (GRADE) }\end{array}$ & Comments \\
\hline Quality of care & $\begin{array}{l}\text { Pooling data across } \\
\text { the } 27 \text { comparisons, } \\
\text { the median improve- } \\
\text { ment in quality of care } \\
\text { associated with the re- } \\
\text { minder intervention } \\
\text { was } 11.0 \% \\
\text { (IQR } 5.4 \% \text { to } 20.0 \% \text { ) }\end{array}$ & $\begin{array}{l}27 \text { studies } \\
\text { (27 comparisons) }\end{array}$ & $\begin{array}{l}\oplus \oplus \oplus \odot \\
\text { MODERATE } 1\end{array}$ & $\begin{array}{l}\text { Quality of care was measured by various } \\
\text { rates: e.g. test ordering rates, vaccination } \\
\text { rates, follow-up rates, prescription rates, } \\
\text { overall compliance rate. }\end{array}$ \\
\hline $\begin{array}{l}\text { Patient out- } \\
\text { comes }\end{array}$ & Not estimable & $\begin{array}{l}4 \text { studies } \\
\text { (4 comparisons) }\end{array}$ & $\begin{array}{l}\oplus \ominus \Theta \Theta \\
\text { VERY LOW2 }\end{array}$ & $\begin{array}{l}\text { No measurable effect on i) blood pressure, } \\
\text { glycated hemoglobin and cholesterol levels, } \\
\text { ii) reaching blood pressure, glycated hemo- } \\
\text { globin and cholesterol targets, and iii) mortal- } \\
\text { ity. }\end{array}$ \\
\hline Adverse effects & Not reported & - & - & $\begin{array}{l}\text { None of the included studies reported out- } \\
\text { comes related to harms or adverse effects of } \\
\text { reminders. }\end{array}$ \\
\hline
\end{tabular}

IQR: interquartile range

\section{GRADE Working Group grades of evidence}

High certainty: Further research is very unlikely to change our confidence in the estimate of effect.

Moderate certainty: Further research is likely to have an important impact on our confidence in the estimate of effect and may change the estimate.

Low certainty: Further research is very likely to have an important impact on our confidence in the estimate of effect and is likely to change the estimate.

Very low certainty: We are very uncertain about the estimate.

1 We downgraded the level of certainty of the evidence from high to moderate because of methodological limitations in the included studies and possible publication bias. We did not find other serious limitations in the other factors (indirectness of evidence, inconsistency of results, and imprecision of results).

2 We downgraded the level of certainty of the evidence from high to very low because of methodological limitations in the included studies, imprecision of results (wide confidence intervals) and inconsistency of the results.

\section{Summary of findings 3.}

Computer-generated reminders delivered on paper to healthcare professionals in addition to one or more co-interventions (multi-component intervention) compared with the co-intervention(s) without the reminder component

Patient or population: Healthcare professionals

Computer-generated reminders delivered on paper to healthcare professionals: effects on professional practice and healthcare outcomes 
Settings: Outpatient care in Canada and USA

Intervention: Computer-generated reminders delivered on paper in addition to one or more co-interventions (multi-component intervention)

Comparison: Co-intervention(s) without the reminder component

\begin{tabular}{|c|c|c|c|c|}
\hline Outcomes & $\begin{array}{l}\text { Median improvement } \\
\text { (interquartile range) }\end{array}$ & $\begin{array}{l}\text { Number of stud- } \\
\text { ies (compar- } \\
\text { isons) }\end{array}$ & $\begin{array}{l}\text { Certainty of the } \\
\text { evidence } \\
\text { (GRADE) }\end{array}$ & Comments \\
\hline Quality of care & $\begin{array}{l}\text { Pooling data across the } \\
13 \text { comparisons, the } \\
\text { median improvement } \\
\text { in quality of care associ- } \\
\text { ated with the reminder } \\
\text { intervention was } 4.0 \% \\
(3.0 \% \text { to } 6.0 \%)\end{array}$ & $\begin{array}{l}11 \text { studies } \\
\text { (13 comparisons) }\end{array}$ & $\begin{array}{l}\oplus \oplus \oplus \ominus \\
\text { MODERATE } 1\end{array}$ & $\begin{array}{l}\text { Quality of care was measured by various } \\
\text { rates: e.g. test ordering rates, vaccination } \\
\text { rates, follow-up rates, prescription rates, } \\
\text { overall compliance rate. }\end{array}$ \\
\hline $\begin{array}{l}\text { Patient out- } \\
\text { comes }\end{array}$ & Not estimable & $\begin{array}{l}2 \text { studies } \\
\text { (3 comparisons) }\end{array}$ & $\begin{array}{l}\oplus \ominus \odot \odot \\
\text { VERY LOW2 }\end{array}$ & $\begin{array}{l}\text { No measurable effect on i) blood pressure, } \\
\text { glycated hemoglobin and cholesterol levels, } \\
\text { ii) reaching blood pressure, glycated hemo- } \\
\text { globin and cholesterol targets, and iii) mor- } \\
\text { tality. }\end{array}$ \\
\hline Adverse effects & Not reported & - & - & $\begin{array}{l}\text { None of the included studies reported out- } \\
\text { comes related to harms or adverse effects of } \\
\text { reminders. }\end{array}$ \\
\hline
\end{tabular}

IQR: interquartile range

GRADE Working Group grades of evidence

High certainty: Further research is very unlikely to change our confidence in the estimate of effect.

Moderate certainty: Further research is likely to have an important impact on our confidence in the estimate of effect and may change the estimate.

Low certainty: Further research is very likely to have an important impact on our confidence in the estimate of effect and is likely to change the estimate.

Very low certainty: We are very uncertain about the estimate.

1 We downgraded the level of certainty of the evidence from high to moderate because of methodological limitations in the included studies and possible publication bias. We did not find other serious limitations in the other factors (indirectness of evidence, inconsistency of results, and imprecision of results).

2 We downgraded the level of certainty of the evidence from high to very low because of methodological limitations in the included studies and imprecision of results (wide confidence intervals). 


\section{B A C K G R O U N D}

\section{Description of the condition}

Clinical practice does not always reflect best evidence, partly because of unconscious acts of omission, information overload or inaccessible information (McDonald 1976). A number of recent studies suggest that fragmented and inaccessible clinical information adversely affects both the cost and quality of health care as well as compromising patient safety (e.g. Anderson 2007). Healthcare professionals are constantly confronted with multiple clinical decisions to be made about diagnosing, treating, and counseling, in various settings. In addition, physicians are increasingly expected to perform tasks related to health maintenance and preventive care that are not directly related to the patient's acute problem, such as cancer screening and chronic disease management. Because the vast amount of information that is needed to achieve appropriate decisions, various support systems have been developed to convey the proper information at the right place and time. A number of interventions have been designed to reduce omissions and the gap between best practice and routine care: educational interventions (directed at clinicians or patients), clinical practice guidelines, reminders (directed at clinicians or patients), audit and feedback of clinical performance, financial incentives, local opinion leaders, information and communication technologies (ehealth) and organizational changes. Previous reviews have shown that such interventions may have the potential to foster better knowledge translation; however the effects are most often modest on average, have shown large variations in practice and are most frequently based on weak quality of evidence (e.g. Baker, 2015; Fiander 2015; Flodgren 2011; Forsetlund 2009; Gagnon 2009; Giguère 2012; Grimshaw 2004; Ivers 2012; Morris 2002; Shojania 2009; Thomas 1999).

\section{Description of the intervention}

According to the US National Library of Medicine, "reminder systems" are approaches, techniques or procedures "used to prompt or aid the memory" of healthcare professionals. "The systems can be computerized reminders, colour coding, telephone calls, or devices such as letters and postcards." (www.ncbi.nlm.nih.gov/pubmed) Reminders have been used for many years and in many different forms. Reminders can be generated electronically or manually, and can be delivered on the computer screen, via email or fax, or in patient paper charts. They also vary in format (e.g. flow chart, electronic message, checklist, sticker) and content (e.g. suggested test date, reference to literature, preventive care suggestions). They can be completely automated and computerized, such as an alert system embedded into computerized provider order entry systems, or completely paper-based without any involvement of a computer, such as simple notes attached by nursing personnel to the front of charts. A third type of reminder, computer-generated reminders delivered on paper, combines the two previous approaches. These are automatically generated through a computerized system, but are delivered on paper to the healthcare professional, usually along with the paper-based medical record, but potentially as a letter they receive outside the consultation.

\section{How the intervention might work}

Reminder systems help clinicians overcome barriers to knowledge transfer, remind them to perform tests or interventions that should be performed regularly, e.g. regular foot examination in diabetic patients or yearly influenza vaccine in elderly patients. Indeed, reminders systems prompt clinicians to recall information that they already know or would be expected to know and by providing information or guidance in a more accessible and relevant format, at a particularly appropriate time. Studies and systematic reviews have indicated that reminders to healthcare professionals can be effective in promoting change in healthcare professional practice across a variety of clinical areas and settings (Balas 2000; Buntinx 1993; Kawamoto 2005; Mandelblatt 1995; Shea 1996; Wensing 1994). Reminder systems have been used to target provider behavior across a range of clinical circumstances including preventive, acute and chronic care and to target various behaviors, such as test ordering, vaccination, drug selection, dosing and prescribing, and improving general disease management.

\section{Why it is important to do this review}

Previous comprehensive and systematic reviews have covered reminders as one of a wide range of interventions aimed at improving professional practice (Davis 1992; Davis 1995; Garg 2005; Grimshaw 2004; Hunt 1998; Johnston 1994;Oxman 1995), or have focused on computerized reminders (Schedlbauer 2009) or the effectiveness of reminders for a specific behavior, such as preventive care (Balas 2000; Dexheimer 2008; Shea 1996), cancer screening (Baron 2010), vaccination (Ndiaye 2005), diabetes care (Balas 2004), or prescribing practices (Bennett 2003; Pearson 2009). In addition, factors that may modify the effectiveness of reminders have not been systematically considered. For example, specific suggestions or advice have been used by several reviews (AxtAdam 1993; Buntinx 1993; Haynes 1987) to distinguish between types of reminder, but few conclusions have been drawn about their impact on the effectiveness of reminders. This may reflect the difficulty of distinguishing explicit advice from implicit advice in many reports of reminder studies. In our view and based on the literature, the effectiveness of reminders may be influenced by their content: whether they provide generic or patient-specific information; whether they require the healthcare professional to record a response; whether they provide a recommendation for care and not just an assessment; whether they include an explanation or justification of the decision support; whether they are explicitly from, or justified by reference to an influential source; and whether reminders are available at point-of-care (Kawamoto 2005; Litzelman 1993). Another potential effect modifier may be the type of targeted behavior. Finally, reminders may also prove useful in low- and middle-income countries; due to a shortage of healthcare workers, support and reminder systems may help volunteer or community health workers to contribute to appropriate care delivery (Mahmud 2010; Tierney 2007). Moreover, a systematic review aimed at evaluating the effectiveness of interventions targeting the transfer of evidence-based information into practice in developing countries did not find conclusive evidence (Siddiqi 2005).

This review is one of a series covering three major categories of reminder and a fourth that will compare all of these. As well as carrying major resource implications, these categories may influence reminder effectiveness. 
- Manual paper reminders: no computer is involved in the production or delivery of the reminder, nor in selecting target patients (Pantoja 2014).

- Computer-generated reminders delivered on paper: a computer is used either to generate paper reminders or to identify patients for whom clinicians should receive a paper reminder.

- On-screen reminders: reminders are delivered to clinicians on computer screen (Shojania 2009).

The primary objective of the series is to guide the development and use of clinical reminder systems. When implementing a reminder system, the decision to use manual methods or a computer to produce or deliver reminders has major resource implications as well as usability implications. Although more and more providers adopt electronic medical records (EMR), their comprehensiveness varies and their widespread use is still limited. In 2001 only $29 \%$ of primary care physicians in the European Union had implemented electronic medical records, while in the USA less than $17 \%$ of primary care physicians routinely use EMRs in their practices (Anderson 2007). Another recent study found that, depending on the definition used, between $8 \%$ and $12 \%$ of U.S. hospitals have a basic electronic-records system (Jha 2009). Using a computer to carry out case finding and to generate paper reminders combines the benefits of the speed and accuracy of computers, compared with manual selection of cases by a person, and the low technology paper delivery method that continues to dominate much clinical practice worldwide.

\section{O B JE C T I VES}

In this review, we examined the effects of reminders automatically generated through a computerized system (computer-generated) and delivered on paper to healthcare professionals on quality of care (outcomes related to healthcare professionals' practice) and patient outcomes (outcomes related to patients' health condition). We addressed the following primary question and subsidiary questions.

- Are computer-generated reminders delivered on paper to healthcare professionals effective in improving quality of care and patient outcomes?

- Are computer-generated reminders delivered on paper to healthcare professionals alone (single-component intervention) more effective than usual care?

- Are computer-generated reminders delivered on paper to healthcare professionals in addition to one or more co-interventions (multi-component intervention) more effective than the co-intervention(s) without the reminder component?

We also addressed the following secondary questions, to identify factors that may systematically modify the effectiveness of reminders, based on features that have been suggested to be effect modifiers in the literature (Baron 2010; Dexheimer 2008; Kawamoto 2005; Litzelman 1993; Mollon 2009; Shiffman 1999).

\section{Content of reminder}

- Are reminders that include some individual patient-specific information more effective than generic reminders (i.e. same message for all patients)?
- Are reminders that include space for a response from the clinician more effective than reminders that do not include this?

- Are reminders that offer specific advice on patient management (i.e. recommendation for care) more effective than reminders that offer general information only (e.g. prevalence of a disease)?

- Are reminders that include an explanation of their content or advice (e.g. background information, risk definition) more effective than reminders that do not include this?

- Are reminders that are explicitly from, or justified by reference to an influential source more effective than anonymous reminders or those from another source? An influential source can be a systematic review, a practice guideline, a bibliographic citation, or a person or body likely to be perceived as credible by the target clinician.

\section{Delivery of reminder}

- Are reminders available at point-of-care (i.e. at patient's visit) more effective than reminders available at another time (e.g. mailed reminders received after patient's visit)?

\section{Behavior targeted by reminder}

- Do reminders vary in effectiveness according to the targeted behavior (e.g. test ordering, prescription)?

\section{METHODS}

\section{Criteria for considering studies for this review}

\section{Types of studies}

We included trials where individuals (patients or providers) or other units (e.g. practice, hospital) were definitely or possibly assigned prospectively by the investigators to one of two (or more) alternative forms of health care using random allocation (randomized trial) or non-random method of allocation (nonrandomized trial) such as alternation, date of birth or medical record number, according to EPOC guidance on study designs (EPOC 2015b). We included non-randomized trials because in complex interventions that are evaluated in routine practice, conducting a randomized trial may be neither feasible nor acceptable. Non-randomized trial designs can be better suited for real-life situations and may better reflect the effectiveness of the intervention.

\section{Types of participants}

Any qualified healthcare professional, or a population where qualified healthcare professionals form the majority of the study population.

\section{Types of interventions}

Reminders are patient- or encounter-specific information, which are designed or intended to prompt a healthcare professional to recall information usually encountered through their general medical education, in the medical records or through interaction with peers, and to remind them to perform or avoid some action to aid individual patient care. Reminders differ from feedback interventions in terms of content: feedback consists of a summary of clinical performance over a specified period of time, and typically aggregates information on multiple patients. Reminders also must not contain any new information about the patient such as a

Computer-generated reminders delivered on paper to healthcare professionals: effects on professional practice and healthcare outcomes $\mathbf{8}$ (Review)

Copyright (c) 2017 The Cochrane Collaboration. Published by John Wiley \& Sons, Ltd. 
laboratory result that is not in the case notes or a score derived from a clinical prediction rule that was previously unknown to the clinician.

This review considered computer-generated reminders delivered on paper. A computer had to be involved in producing the reminder for eligible patients or in selecting the patients about whom the clinician received a reminder, or both. If a computer was merely used as a medium to print the reminder without any other function, the reminder was not considered as computer-generated. We also included applications of computerized algorithms to identify eligible patients, for whom the prompt is printed out and placed in the chart. Information was usually obtained from computerized medical records or a computerized database. Once generated, the reminder had to be delivered on paper (fax included), and not on a computer screen or via email or text message.

To be included in the review, the reminder had to target a healthcare professional who delivered the care directly to patients, not an intermediary (e.g. clinic receptionist, clinician manager). Expert systems for facilitating diagnosis or estimating prognosis were not considered as reminders, even if their output was printed out. A document listing all the drugs a patient was currently taking (e.g. drug profile) or a document summarizing the medical records, with no rules applied in the computer, were not considered as reminders, but as an organizational intervention (i.e. changes in the medical records systems). New clinical information collected directly from patients on a computer and given to the provider as a prompt was not considered as a reminder intervention, but as a patient-mediated intervention.

\section{Types of outcome measures}

Quality of care is the primary outcome of this review as the main purpose of reminders is to change healthcare professional practice and affect a quality of care endpoint, such as ordering a test or initiating a treatment. This targeted practice change should, in turn, improve patient outcomes, based on evidence. Thus, if the reminder is aimed at modifying a drug prescription for a simpler or cheaper treatment, the latter prescription should have been shown as having at least similar effectiveness as the current treatment (indirect evidence). Studies of reminders rarely target changes in patient outcomes directly. Moreover, the targeted modification may not be linked to an actual change in patient outcome, for instance when replacing a proprietary drug by a generic equivalent.

\section{Primary outcomes}

Quality of care

- Dichotomous outcomes related to healthcare professionals' practice: the percentage of patients receiving a target process of care (e.g. ordering of a test, prescription for a medication) or whose care was in compliance with an overall guideline (e.g. percentage of women up-to-date with a breast cancer screening recommendation). Instead of patients in the denominator, this could be patient encounters or reminders (e.g. number of recommendations followed over the number of recommendations due during an encounter).

- Continuous outcomes related to healthcare professionals' practice: any continuous measure of how providers delivered care (e.g. duration of therapy, time to event).

\section{Secondary outcomes}

Patient outcomes

- Dichotomous outcomes related to patients' health condition: the percentage of clinical endpoints (e.g. death, development of a disease such as pneumonia, stroke, heart attack, etc.) or the percentage of surrogate or intermediate endpoints, such as a continuous measures of disease control that have been dichotomized and reported as percentage of patients with sufficient or insufficient control (e.g. percentage of diabetics reaching the glycated hemoglobin target $(<7 \%)$, percentage of patients reaching systolic blood pressure target $(<140 \mathrm{mmHg})$ ).

- Continuous outcomes related to patients' health condition: various markers of disease or health status (e.g. blood pressure, body mass index, glycated hemoglobin levels) that were captured and analyzed as continuous variables.

Adverse effects outcomes: any adverse effects described in the study, such as redundant testing or overdiagnosis.

\section{Search methods for identification of studies}

\section{Electronic searches}

The Information Specialist for the EPOC Group conducted the searches on 21 September 2016; exact search dates, search terms, syntax and number of results are provided for each database and may be found in Appendix 1. Previous searches can be found in the previous version of the review (Arditi 2012).

We searched the following databases.

- Cochrane Central Register of Controlled Trials (CENTRAL; 2016, Issue 8) in the Cochrane Library

- Cochrane Database of Systematic Reviews (CDSR; 2016, Issue 9) in the Cochrane Library

- Health Technology Assessment Database (HTA; 2016, Issue 3) in the Cochrane Library

- Database of Abstract of Reviews of Effectiveness (DARE; 2015, Issue 2) in the Cochrane Library

- NHS Economic Evaluations Database (NHSEED; 2015, Issue 2) in the Cochrane Library

- MEDLINE via OVID (from 1946)

- Embase via OVID (from 1974)

- CINAHL (Cumulative Index to Nursing and Allied Health Literature) via Ebscohost (from 1980)

- INSPEC via Web of Science(from 1969)

\section{Searching other resources}

In addition to database searching, we examined reference lists of key articles and relevant reviews, handsearched the WHO International Clinical Trials Registry (http://apps.who.int/ trialsearch/), the US National Institutes of Health (NIH) Clinical Trials Registry (http://clinicaltrials.gov/) and contacted authors of relevant reviews and studies regarding any further published or unpublished work.

\section{Data collection and analysis}

For this update, we used the same data collection tool defined in the protocol and used in the previous version of this systematic review (Arditi 2012). 


\section{Selection of studies}

Two assessors (JW, SY), working independently, screened titles and abstracts of references located by the literature search for potential relevance. We retrieved full-text copies of all potentially relevant studies for full-text assessment. Many studies were rated as potentially relevant in the first selection process, as it was often unclear whether computerized reminders were provided to the healthcare professional on paper or on a computer screen, and whether the reminders were computer-generated. Two assessors, again working in pairs (CA, SY), independently assessed studies for inclusion. Studies that appear to meet the inclusion criteria, but on closer examination failed to, are detailed in the table of excluded studies.

\section{Data extraction and management}

Two assessors independently carried out data extraction (SY, CA), using the EPOC Data Collection Checklist modified to capture more detailed information in some areas (e.g. content of the reminder). Any discrepancies between assessors arising from the inclusion assessment or from the data extraction process were resolved by discussion and the involvement of a third review author. Decisions that could not be resolved easily were referred to the EPOC contact editor.

\section{Assessment of risk of bias in included studies}

The risk of bias for all included studies was independently assessed in pairs (SY, CA) using the nine suggested risk of bias criteria for EPOC reviews (EPOC 2015a).

\section{Measures of treatment effect}

For each study we reported the main results in natural units in a results table. Where baseline results were available, preintervention proportions and means were also reported for both study and control groups. The unadjusted and adjusted (for baseline imbalance) differences (in proportion or mean) between study and control groups at endpoint were calculated for the outcomes. The direction of the effect size was standardized so that a positive difference between post-intervention percentages or means indicated a positive outcome.

\section{Unit of analysis issues}

We anticipated that cluster-randomized trials would be common, which is often the case in interventions aimed at healthcare professionals. There is a high risk of contamination when patients are randomized rather than professionals since clinicians' experience of applying the intervention to patients receiving the experimental management may contaminate the way they treat control patients (Biau 2008; Kahan 2013). We also expected that such trials would rarely take into account the cluster effect in the analysis (i.e. unit of analysis error resulting in artificially extreme $P$ values and over narrow confidence intervals (Ukoumunne 1999). Performing a meta-analysis involving both trials randomizing patients and clusters would require us to make assumptions about unknown parameters, such as intra-class correlation coefficients and the distribution of patients across clusters, to avoid spurious precision in 95\% confidence intervals. In addition, we expected a large variety of interventions, outcomes and response scales, as well as a very wide contextual and clinical heterogeneity in existing studies' reports. We thus decided to report the median improvement and interquartile range (IQR) across the included studies in order to avoid unit of analysis issues when combining results from cluster- and patient-randomized trials.

\section{Dealing with missing data}

No data were missing.

\section{Assessment of heterogeneity}

We explored heterogeneity visually by preparing box plots displaying median effects and IQRs (see Subgroup analysis and investigation of heterogeneity for further details).

\section{Assessment of reporting biases}

We explored the possibility of publication bias by plotting the number of patients and professionals included in the studies against the median effect size.

\section{Data synthesis}

We combined cluster- and patient-randomized trials using the median improvement and IQR. This approach was first developed in a large review of guideline dissemination and implementation strategies (Grimshaw 2004) and used in the systematic review on the effects of on-screen, point-of-care reminders (Shojania 2009). Briefly, each study is represented by a single representative outcome and the median effect size and IQR are calculated across the included studies. By using the median rather than the mean, the summary estimate is less likely to be influenced by outlying results (e.g. large effects from methodologically poor studies). In contrast to conventional meta-analysis, where each study is given a weight based on the precision of the results, here each study is given equal weight. The impact of study size and various methodological features were investigated in pre-specified subgroup analyses.

The representative outcome of studies reporting more than one outcome was the primary outcome measure when it was defined as such by the authors of the study. If authors did not specify the primary outcome but provided an aggregated outcome (e.g. overall physician compliance), we selected that aggregated outcome as a representative outcome. If a primary outcome was not available, we calculated the median effect size across all reported outcomes. For example, if the study reported five dichotomous quality of care outcomes and none of them were denoted the primary outcome, we ranked the effect sizes for the five quality of care outcomes and took the median value. If there was an even number of outcomes, we calculated the average of the two middle outcomes.

\section{Summary of findings}

We summarized the findings in three 'Summary of findings' tables to draw conclusions about the certainty of the evidence. Two review authors $(B B, C A)$ independently assessed the certainty of the evidence (high, moderate, low, and very low) using the five GRADE considerations (study limitations, consistency of effect, imprecision, indirectness, and publication bias) (Guyatt 2011). We used methods and recommendations described in Section 8.5 and Chapter 12 of the Cochrane Handbook for Systematic Reviews of Interventions (Higgins 2011), the EPOC worksheets (EPOC 2015C), and by using GRADEpro software (GRADEpro GDT 2015). We resolved disagreements on certainty ratings by discussion and provided justification for decisions to down- or up-grade the ratings using footnotes in the tables and made comments to aid readers' understanding of the review where necessary. We used 
plain language statements to report these findings throughout the review.

\section{Subgroup analysis and investigation of heterogeneity}

We compared the median improvement across studies according to the following potential effect modifiers, pre-defined in the protocol and based on features that have been suggested to be effect modifiers in the literature (Baron 2010; Dexheimer 2008; Kawamoto 2005; Litzelman 1993; Mollon 2009; Shiffman 1999):

- patient-specific: whether the reminder provided generic knowledge or advice with no patient data or patient-specific advice (i.e. same message or advice for all patients) or patientspecific knowledge or advice;

- space for response: whether the reminder provided space for the healthcare professional to record a response/comment (e.g. a box to tick or line to write on) or not;

- specific advice: whether the reminder provided advice on patient management or recommendation for care (e.g. consider reducing dosage of drug) or not (e.g. prevalence of disease);

- explanation: whether the reminder was supported by an explanation (e.g. background information, definitions, risks, rationale) or not (e.g. last pap smear test date);

- reference: reminders were explicitly from or justified by reference to an influential source (e.g. clear reference to a systematic review or national guidelines) or not;

- at point-of-care: whether the reminder was delivered to healthcare professional when providing care to the patient (at point-of-care) or not (e.g. reminder sent by mail after patient's visit).

We also compared the median improvement across studies according to the type of behavior targeted by the reminder (e.g. prescription, test ordering) and the following features of the study: study design, allocation method, sample size (patients and professionals), setting, country, duration of intervention, and publication year. We also investigated the median improvement in disadvantaged populations, in terms of economic status, place of residence and ethnicity.

We used the non-parametric Wilcoxon rank-sum test (also known as the Mann-Whitney two-sample statistic) for two-levels variables and the Kruskal-Wallis test for variables with more than two levels. We performed all statistical analyses using Stata version 10 (Stata 2007).

\section{Sensitivity analysis}

We performed sensitivity analyses based on study design criteria deemed important in the context of this review (only including studies with allocation concealment and complete outcome data) and data availability (excluding trials where data were estimated from graphs). We also re-analyzed the data using three alternative methods for representing the outcome from each study: using the median outcome as representative outcome, even for studies reporting a primary outcome; using the reported outcome showing the largest improvement (largest outcome); and using the reported outcome showing the smallest improvement (smallest outcome).

\section{RES U L T S}

\section{Description of studies}

See: Characteristics of included studies; Characteristics of excluded studies.

\section{Results of the search}

See: Figure 1.

Figure 1. Study flow diagram *Ineligible comparison or inappropriate control: e.g. physician reminder combined with another intervention vs usual care, physician reminder with a specific feature vs physician reminder without it, 
physician reminder vs another intervention \$Not a provider reminder: e.g. audit and feedback, changes in medical records system, expert system for estimating diagnosis/risk/dosage, patient-mediated intervention

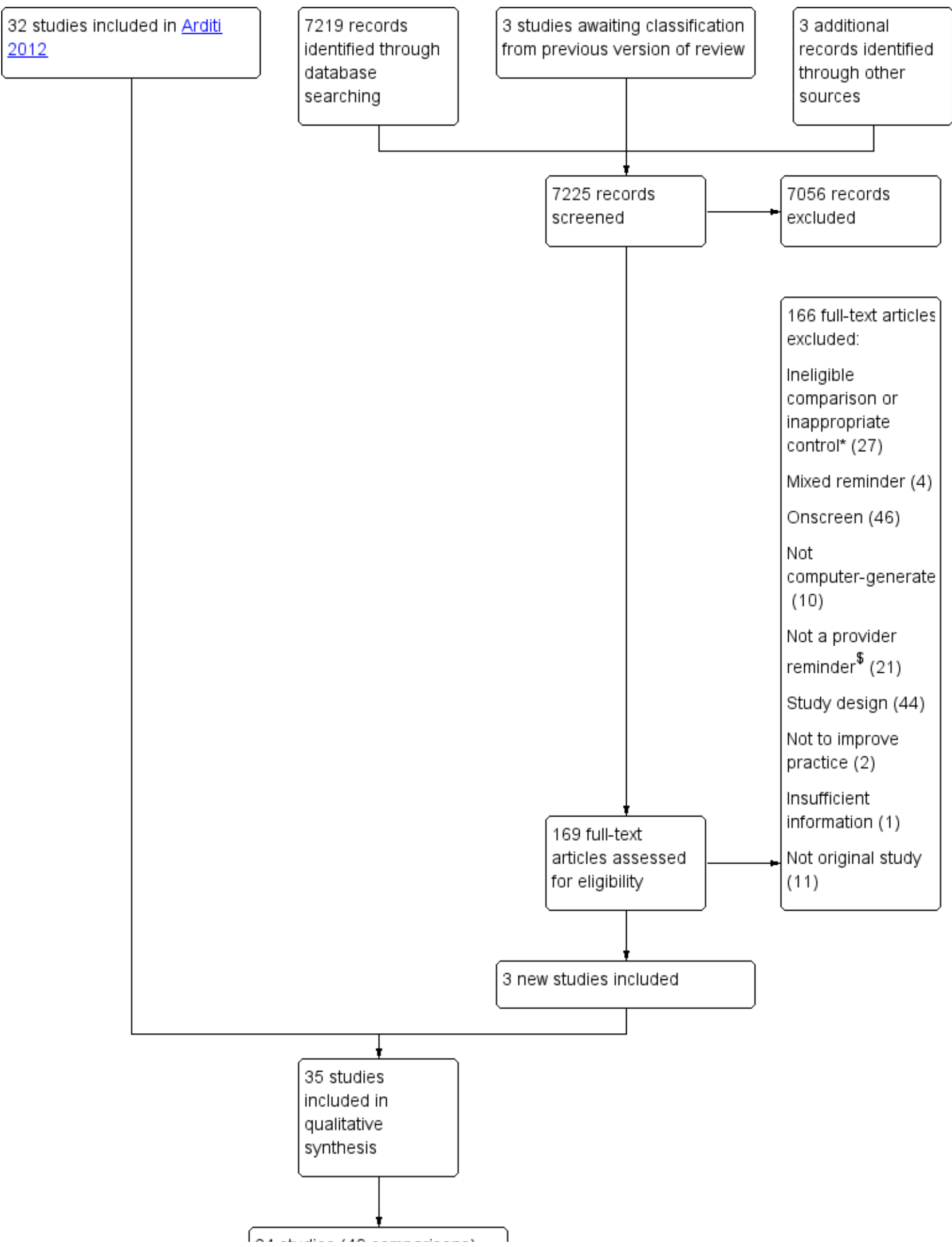

Computer-generated reminders delivered on paper to healthcare professionals: effects on professional practice and healthcare outcomes 
Figure 1. (Continued)

34 studies (40 comparisons)
included in quantitative
synthesis (median analysis)

We identified 7225 records (including three studies awaiting classification in the original review and three studies identified via handsearching), of which 7056 were excluded after screening the title and abstract. After assessing full-texts for the remaining 169 records, we retained three new studies (Gilutz 2009; Le Breton 2016; Were 2013). In total, we included 35 studies in the qualitative synthesis and 34 studies in the quantitative synthesis (one study did not report usable outcome data). Six studies (Burack 1996; Burack 1998; McPhee 1989; Ornstein 1991; Tierney 1986; Ziemer 2006) contained four study groups (i.e. reminders alone, reminders with co-intervention(s), cointervention(s) without reminder component, usual care), resulting in 40 eligible comparisons in the quantitative analyses.

\section{Included studies}

\section{Design}

Thirty studies were randomized trials, including one cross-over trial (McDonald 1980), and five studies were non-randomized trials (Mazzuca 1990; McDonald 1976a; Morgan 1978; Oniki 2003; Turner 1989), including one cross-over trial (McDonald 1976a). Among the 35 included studies, 15 allocated patients to study groups (Barnett 1983; Becker 1989; Binstock 1997; Burack 1996; Burack 1998; Chambers 1989; Heidenreich 2005; Heidenreich 2007; Javitt 2005; McDonald 1976b; Morgan 1978; Oniki 2003; Thomas 1983; Were 2013; White 1984), while the other studies used cluster-allocation methods. The unit of allocation was the health professional in 10 studies (Chambers 1991; Le Breton 2016; Lobach 1997; Majumdar 2007; McAlister 2009; McDonald 1976a; McDonald 1980; McPhee 1989; Nilasena 1995; Rossi 1997), the clinic, clinic session or health professional team in nine studies (Dexter 1998; Gilutz 2009; Heiman 2004; Mazzuca 1990; McDonald 1984; Ornstein 1991; Tierney 1986; Turner 1989; Ziemer 2006), and the family in one study (Rosser 1991).

\section{Participants, setting and publication date}

All studies included at least 100 patients in the analyses (median 751, mean 2275); the number of patients was not reported in two studies (Javitt 2005; McDonald 1980). The healthcare professionals were primarily physicians, although some studies also included other professionals such as nurse practitioners. One study included only nurses (Oniki 2003). Healthcare professionals' level of training varied across studies. In the cluster-randomized studies, the number of professionals, for whom outcome data were obtained, varied between nine and 600 (median 57, mean 104).

Most included studies were based in North America (29 in the USA, three in Canada). The three remaining studies were based in France (Le Breton 2016), Israel (Gilutz 2009), and Kenya (Were 2013). Most studies took place in outpatient settings, while two took place in inpatient settings (Oniki 2003; White 1984) and three in mixed settings (Heidenreich 2005; Heidenreich 2007; Javitt 2005).
About 70\% of the studies were published between 1980 and 2000 .

\section{Interventions}

Physician reminders alone (single-component intervention) were compared with usual care in 28 studies (Barnett 1983; Becker 1989; Binstock 1997; Burack 1996; Burack 1998; Chambers 1989; Chambers 1991; Dexter 1998; Gilutz 2009; Heidenreich 2005; Heidenreich 2007; Heiman 2004; Javitt 2005; Le Breton 2016; Lobach 1997; McDonald 1976a; McDonald 1976b; McDonald 1980; McDonald 1984; McPhee 1989; Morgan 1978; Oniki 2003; Rosser 1991; Rossi 1997; Thomas 1983; Tierney 1986; Were 2013; White 1984). Physician reminders in addition to one or more cointerventions (multi-component intervention) were compared with the co-intervention(s) without the reminder component in 11 studies. There was one co-intervention in seven studies (Burack 1996; Burack 1998; Majumdar 2007; Mazzuca 1990; McAlister 2009; Nilasena 1995; Tierney 1986), two co-interventions in four studies (McPhee 1989; Ornstein 1991; Turner 1989; Ziemer 2006), and three co-interventions in study groups of two studies (Ornstein 1991; Ziemer 2006). The most common co-interventions were patient reminder, educational meeting for healthcare professionals, and audit and feedback.

The same reminder was provided for all eligible patients (e.g. order a pap smear test) in 15 comparisons. Between two and 10 different reminders could be provided for patients in 19 studies, while over 10 different reminders could be provided for eligible patients in the remaining seven comparisons (McDonald 1980; McDonald 1984; Nilasena 1995; Thomas 1983; Tierney 1986; Tierney 1986; Were 2013).

The categorization of reminders for each included study is provided in the Characteristics of included studies tables. Reminders in all comparisons except one (Chambers 1991) were patient-specific. The use of the computer to select patients allowed the reminders to be sent to eligible patient records only and thus be patientspecific. Reminders in 19 comparisons included space for the provider to respond to the reminder (e.g. a check box to order a mammogram). Reminders offered specific advice on patient management (i.e. recommendation for care) in 35 comparisons and included an explanation of their content or advice (e.g. background information, risk definition) in 13 comparisons. Reminders were explicitly from or justified by reference to an influential source (e.g. systematic review, bibliographic citation) in 11 comparisons. Reminders were provided to physicians at the point-of-care (i.e. during the patient's visit) in all comparisons except five, where reminders were sent after patients' visits directly to physicians.

The median duration of the reminder intervention was 11 months (range two to 56 months); the duration was not reported in two studies (Binstock 1997; Dexter 1998). 


\section{Clinical domain and targeted behavior}

Reminders were aimed at prompting the physicians to provide preventive care services in half of the comparisons. In these studies, the most common objective was to enhance compliance with cancer screening tests (e.g. mammography, Papanicolaou smear, rectal examination) or vaccination. In the remaining comparisons, reminders were provided to physicians seeing patients with an acute or chronic condition, such as diabetes, HIV and cardiovascular disease, to enhance compliance with disease management guidelines (e.g. foot examination in diabetes patients, blood pressure check in hypertensive patients, prescribing angiotensin converting enzyme (ACE) inhibitors in patients with cardiovascular problems).

In 23 comparisons, reminders targeted one type of behavior. The behavior was test ordering (e.g. mammography, glycated hemoglobin) in 10 comparisons, vaccination in one comparison, prescribing in seven comparisons, professionalpatient communication in two comparisons, and general management in three comparisons. In the remaining 17 comparisons, reminders targeted multiple behaviors: two types of behaviors in nine comparisons and three or four types of behaviors in the other eight comparisons. In one comparison, the number of behaviors was unclear.

\section{Outcome measures}

There were large variations in the kind of outcome measure, and many studies reported multiple outcomes, especially studies on compliance with more than one guideline. Most trials measured quality of care outcomes, such as prescribing or test ordering rates. Six studies also reported patient outcomes such as blood pressure or cholesterol levels (Barnett 1983; Gilutz 2009; Heidenreich 2005;
McAlister 2009; Rossi 1997; Ziemer 2006). All studies except one (Oniki 2003) reported at least one dichotomous quality of care outcome.

\section{Excluded studies}

We excluded 166 studies in this update, in addition to the 297 studies excluded in the original review. Twenty-seven studies were excluded because of ineligible comparison or inappropriate control (e.g. physician reminder combined with another intervention versus usual care, physician reminder with a specific feature versus physician reminder without it, physician reminder versus another intervention). Four studies were excluded because reminders were presented to physicians on paper and onscreen at the same time, thus not allowing us to determine the effect of the paper reminder alone. When we retrieved full-texts, we found that reminders in 46 studies were presented to physicians on a computer screen or sent by email. Computers were not involved in generating the reminder in 10 studies. In 21 studies, interventions were not provider reminders (e.g. audit and feedback, changes in medical records system, expert system for estimating diagnosis/ risk/dosage, patient-mediated intervention). Fourty-four studies were excluded because of study design and 11 because the publication was not an original study. We excluded two studies because their objective was not to improve professional practice and one study did not provide sufficient information to determine its eligibility. We listed 52 of the 166 excluded studies in the Characteristics of excluded studies that may appear to meet the eligibility criteria to readers.

\section{Risk of bias in included studies}

See Figure 2; Figure 3 for summaries of risk of bias, and the Characteristics of included studies for details of risk of bias in each study. 
Figure 2. Methodological quality summary: review authors' judgements about each methodological quality item for each included study.

\begin{tabular}{|c|c|c|c|c|c|c|c|c|c|}
\hline & 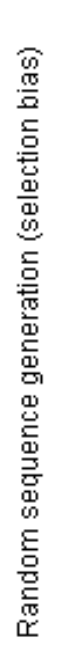 & 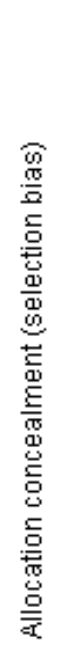 & 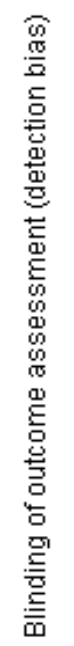 & 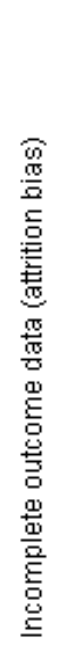 & 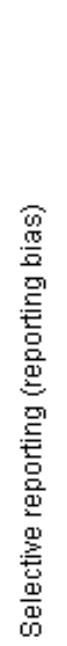 & 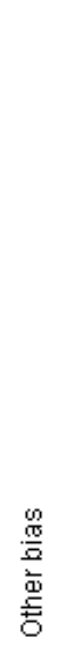 & 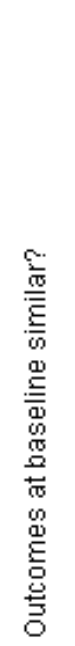 & 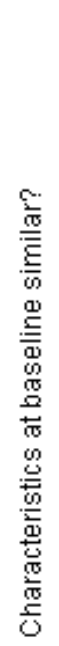 & 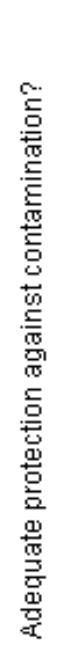 \\
\hline Barnett 1983 & $?$ & $?$ & $?$ & + & $?$ & $?$ & $?$ & + & $\odot$ \\
\hline Becker 1989 & $?$ & $?$ & $?$ & + & $?$ & $?$ & $?$ & + & $\odot$ \\
\hline Binstock 1997 & $?$ & $?$ & + & $?$ & $?$ & $?$ & $?$ & $?$ & $\Theta$ \\
\hline Burack 1996 & $?$ & $?$ & + & $\odot$ & $?$ & $?$ & $?$ & + & - \\
\hline Burack 1998 & $?$ & $?$ & $?$ & - & $?$ & $?$ & $?$ & + & $\odot$ \\
\hline Chambers 1989 & + & $?$ & $?$ & $?$ & $?$ & $?$ & + & + & $\Theta$ \\
\hline Chambers 1991 & $\odot$ & $?$ & $?$ & $\odot$ & $?$ & $?$ & $?$ & $?$ & + \\
\hline Dexter 1998 & $?$ & $?$ & $\odot$ & $\odot$ & $?$ & $?$ & $?$ & $\odot$ & + \\
\hline Gilut 2009 & $?$ & $?$ & $\odot$ & $\odot$ & $\Theta$ & $?$ & $?$ & $\odot$ & $\odot$ \\
\hline Heidenreich 2005 & $\odot$ & $\odot$ & $?$ & $\odot$ & $?$ & $?$ & + & + & - \\
\hline Heidenreich 2007 & $\odot$ & + & + & $\odot$ & $?$ & $?$ & $\odot$ & $\odot$ & - \\
\hline Heiman 2004 & $\odot$ & + & $\odot$ & $\odot$ & $?$ & $?$ & $?$ & $\odot$ & + \\
\hline Javitt 2005 & $\odot$ & $\odot$ & $?$ & $\odot$ & $?$ & $?$ & $?$ & $\odot$ & $\odot$ \\
\hline Le Breton 2016 & + & + & + & + & $\odot$ & $?$ & + & $\Theta$ & + \\
\hline Lobach 1997 & $\odot$ & + & $\odot$ & + & $?$ & $?$ & 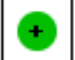 & $\oplus$ & + \\
\hline Majumdar 2007 & $\odot$ & $\odot$ & $\odot$ & $\odot$ & $\Theta$ & + & $?$ & + & + \\
\hline Mazzuca 1990 & $\odot$ & - & + & $?$ & $?$ & $?$ & + & $?$ & + \\
\hline McAlister 2009 & $\oplus$ & + & + & + & $\odot$ & + & + & + & + \\
\hline McDonald 1976a & $\odot$ & - & $?$ & $?$ & $?$ & $?$ & $?$ & $?$ & $\Theta$ \\
\hline McDonald 1976b & $\odot$ & $?$ & $?$ & $?$ & $?$ & $?$ & $?$ & $?$ & $\odot$ \\
\hline McDonald 1980 & $?$ & $?$ & $?$ & $?$ & $?$ & $?$ & $?$ & $?$ & 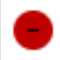 \\
\hline MAnRmmald 1 Bo & $=$ & 0 & a & a & $=$ & 0 & $=$ & a & \\
\hline
\end{tabular}


Figure 2. (Continued)

\begin{tabular}{|c|c|c|c|c|c|c|c|c|c|}
\hline toratus & & & & & & & & 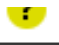 & \\
\hline McDonald 1984 & $?$ & $?$ & + & + & $?$ & $?$ & $?$ & $\odot$ & $?$ \\
\hline McPhee 1989 & $?$ & $?$ & + & $\odot$ & $?$ & $?$ & + & $?$ & + \\
\hline Morgan 1978 & $\odot$ & - & $?$ & $?$ & $?$ & $?$ & $?$ & $?$ & - \\
\hline Nilasena 1995 & $?$ & $?$ & $?$ & $\odot$ & $?$ & $?$ & $\odot$ & $?$ & $\odot$ \\
\hline Oniki 2003 & $\odot$ & $\odot$ & + & $?$ & $?$ & $?$ & $?$ & $?$ & - \\
\hline Ornstein 1991 & $?$ & $?$ & + & $?$ & $?$ & $?$ & $\odot$ & $\odot$ & + \\
\hline Rosser 1991 & + & $?$ & $?$ & $\oplus$ & $?$ & $?$ & $?$ & $\oplus$ & $?$ \\
\hline Rossi 1997 & + & $\odot$ & + & $?$ & $?$ & $?$ & $?$ & $\odot$ & + \\
\hline Thomas 1983 & $?$ & $?$ & $?$ & $\odot$ & $?$ & $?$ & $?$ & $?$ & - \\
\hline Tierney 1986 & $?$ & $?$ & + & $?$ & $?$ & + & $?$ & $?$ & + \\
\hline Turner 1989 & $\odot$ & $\Theta$ & $\Theta$ & $?$ & $\Theta$ & $?$ & $\Theta$ & $\odot$ & + \\
\hline Were 2013 & + & $?$ & $\odot$ & $?$ & + & $?$ & $?$ & $\odot$ & $\Theta$ \\
\hline White 1984 & + & $?$ & $\oplus$ & $?$ & $?$ & $?$ & $?$ & + & - \\
\hline Ziemer 2006 & $?$ & $?$ & $?$ & $?$ & $?$ & $?$ & + & $\odot$ & + \\
\hline
\end{tabular}

Figure 3. Methodological quality graph: review authors' judgements about each methodological quality item presented as percentages across all included studies.

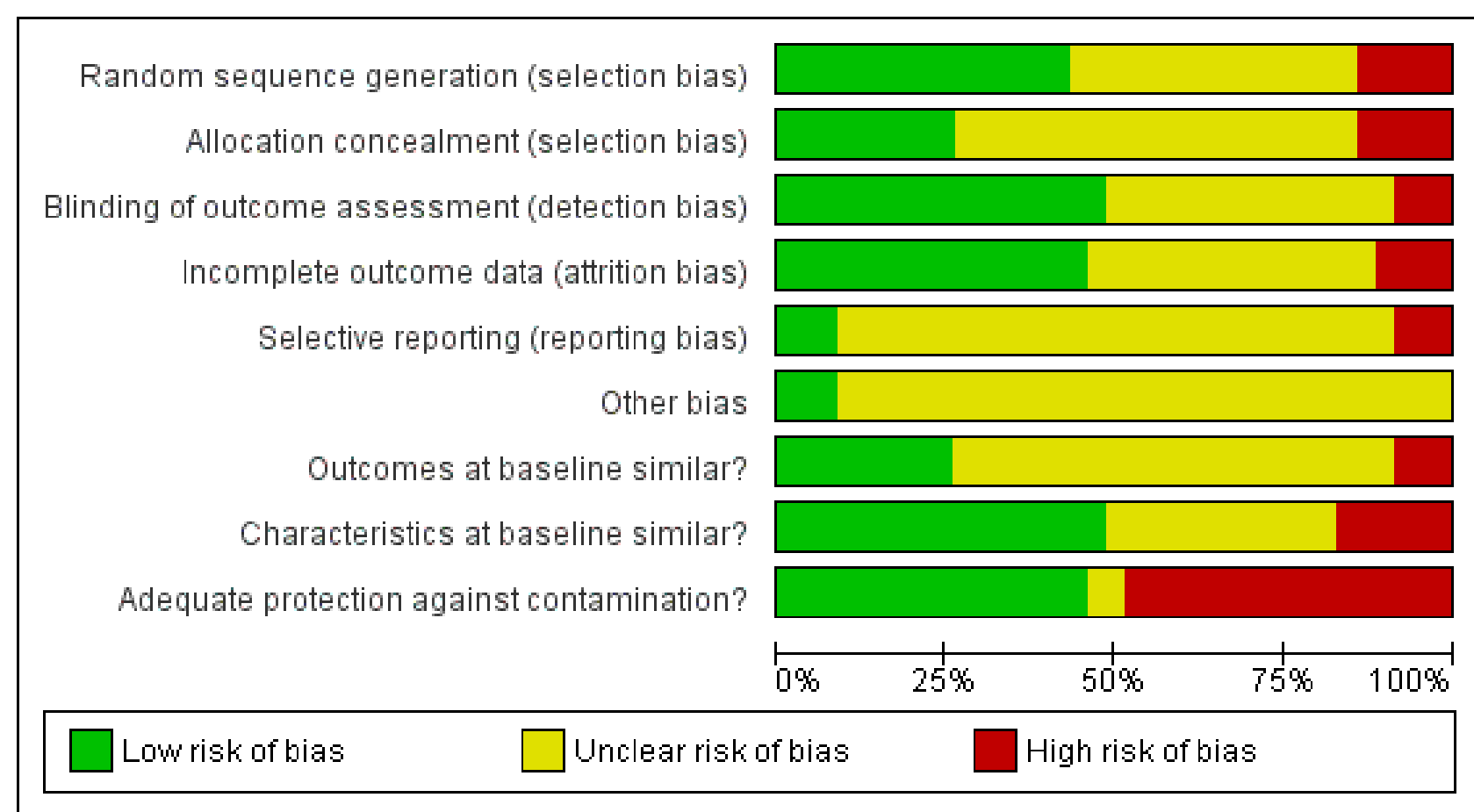




\section{Allocation}

Among the 30 randomized trials, the 15 studies that described the sequence generation by referring to a computerized randomization program or a random number table (Chambers 1989; Chambers 1991; Heidenreich 2005; Heidenreich 2007; Heiman 2004; Javitt 2005; Le Breton 2016; Lobach 1997; Majumdar 2007; McAlister 2009; McDonald 1976b; Rosser 1991; Rossi 1997; Were 2013; White 1984) were at low risk of bias. The process of sequence generation was unclear for the other 15 randomized trials, which merely stated that the study groups were randomly allocated (Barnett 1983; Becker 1989; Binstock 1997; Burack 1996; Burack 1998; Dexter 1998; Gilutz 2009; McDonald 1980; McDonald 1984; McPhee 1989; Nilasena 1995; Ornstein 1991; Thomas 1983; Tierney 1986; Ziemer 2006). Allocation concealment occurred in nine randomized trials, while it was unclear in the remaining randomized trials.

The five non-randomized trials were at high risk of bias for sequence generation and allocation concealment.

\section{Unit of allocation issues}

Of the 20 studies with a cluster design, only seven analyzed results at the level of the cluster (Lobach 1997; Mazzuca 1990; McPhee 1989; Nilasena 1995; Tierney 1986; Turner 1989; Ziemer 2006), while the other studies analyzed results at the patient level (Chambers 1991; Dexter 1998; Gilutz 2009; Heiman 2004; Le Breton 2016; Majumdar 2007; McAlister 2009; McDonald 1984; Ornstein 1991; Rosser 1991, Rossi 1997) or the reminder level (McDonald 1976a; McDonald 1980). Such unit of analysis errors artificially increase the precision of statistical tests and may lead to inappropriate conclusions. Five of these studies re-analyzed the data taking into account the clustering effect (Dexter 1998; Heiman 2004; Le Breton 2016; McAlister 2009; Rossi 1997). One study (Majumdar 2007) minimized the unit of analysis error by not allowing physicians to contribute more than five patients.

\section{Blinding}

Due to the nature of the intervention, blinding was only assessed with regards to the outcome assessment method. Five studies reported that outcome assessors were blinded (Dexter 1998; Le Breton 2016; Majumdar 2007; McAlister 2009; White 1984) and two studies performed an audit of outcome assessments (Lobach 1997; McPhee 1989). Ten further studies reported that outcomes were derived from a computerized medical records system, minimizing risk of bias (Binstock 1997; Burack 1996; Gilutz 2009; Heidenreich 2007; Mazzuca 1990; McDonald 1984; Oniki 2003; Ornstein 1991; Rossi 1997; Tierney 1986). While two studies reported that outcomes were not assessed blindly (Heiman 2004; Turner 1989); the other studies did not report on blinding procedures.

\section{Incomplete outcome data}

Outcome data were considered complete when $80 \%$ or more of the patients randomized were included in the analyses or when reasons for attrition were similar across groups. These were reported in 16 studies (Barnett 1983; Becker 1989; Burack 1996; Chambers 1991; Dexter 1998; Gilutz 2009; Heidenreich 2005; Heidenreich 2007; Heiman 2004; Javitt 2005; Le Breton 2016; Lobach 1997; Majumdar 2007; McAlister 2009; McDonald 1984; Rosser 1991). Outcome data were considered incomplete in four studies, where the percentage of patients analyzed was less than $80 \%$ of patients randomized and no reason was given for the missing data (Burack 1998; McPhee 1989; Nilasena 1995; Thomas 1983). In the remaining studies, the number of patients lost to follow-up was unclear.

\section{Other potential sources of bias}

Baseline measurement of the outcome of interest was reported in 13 studies. Among these studies, 10 reported that study groups were comparable at baseline (Chambers 1989; Heidenreich 2005; Heidenreich 2007; Heiman 2004; Le Breton 2016; Lobach 1997; Mazzuca 1990; McAlister 2009; McPhee 1989; Ziemer 2006), while three reported significant differences (Nilasena 1995; Ornstein 1991; Turner 1989). Across studies reporting a baseline measurement of outcome, the median difference between intervention and control groups at baseline was $1 \%$.

Two thirds of the studies reported patient characteristics at baseline that permitted assessment of baseline heterogeneity in characteristics between study groups. Six studies reported significant differences (Dexter 1998; Gilutz 2009; Heiman 2004; Le Breton 2016; Ornstein 1991; Rossi 1997).

Lack of protection against contamination is a potential source of bias in interventions targeting healthcare professionals. Indeed, there is a risk that physicians who receive reminders for some patients but no reminders for other patients may improve their behavior in both groups, thus reducing the chance of measuring a difference between the study groups. Sixteen studies prevented contamination by allocating physicians or practices to study groups, eliminating the risk of physicians receiving reminders for some patients and no reminders for others.

\section{Effects of interventions}

See: Summary of findings for the main comparison; Summary of findings 2; Summary of findings 3

The outcomes considered for each study included in the analyses are described in detail in Table 1 . The absolute improvement in quality of care for studies reporting a primary outcome and the median improvement and interquartile range (IQR) for studies reporting more than one eligible outcome are displayed in Figure 4. 
Figure 4. Absolute improvement of quality of care by study, using the primary outcome defined by authors (represented by a red dot), and median improvement by study, using the median outcome of all reported quality of care outcomes (represented by a blue square (the median) and blue line (interquartile range))

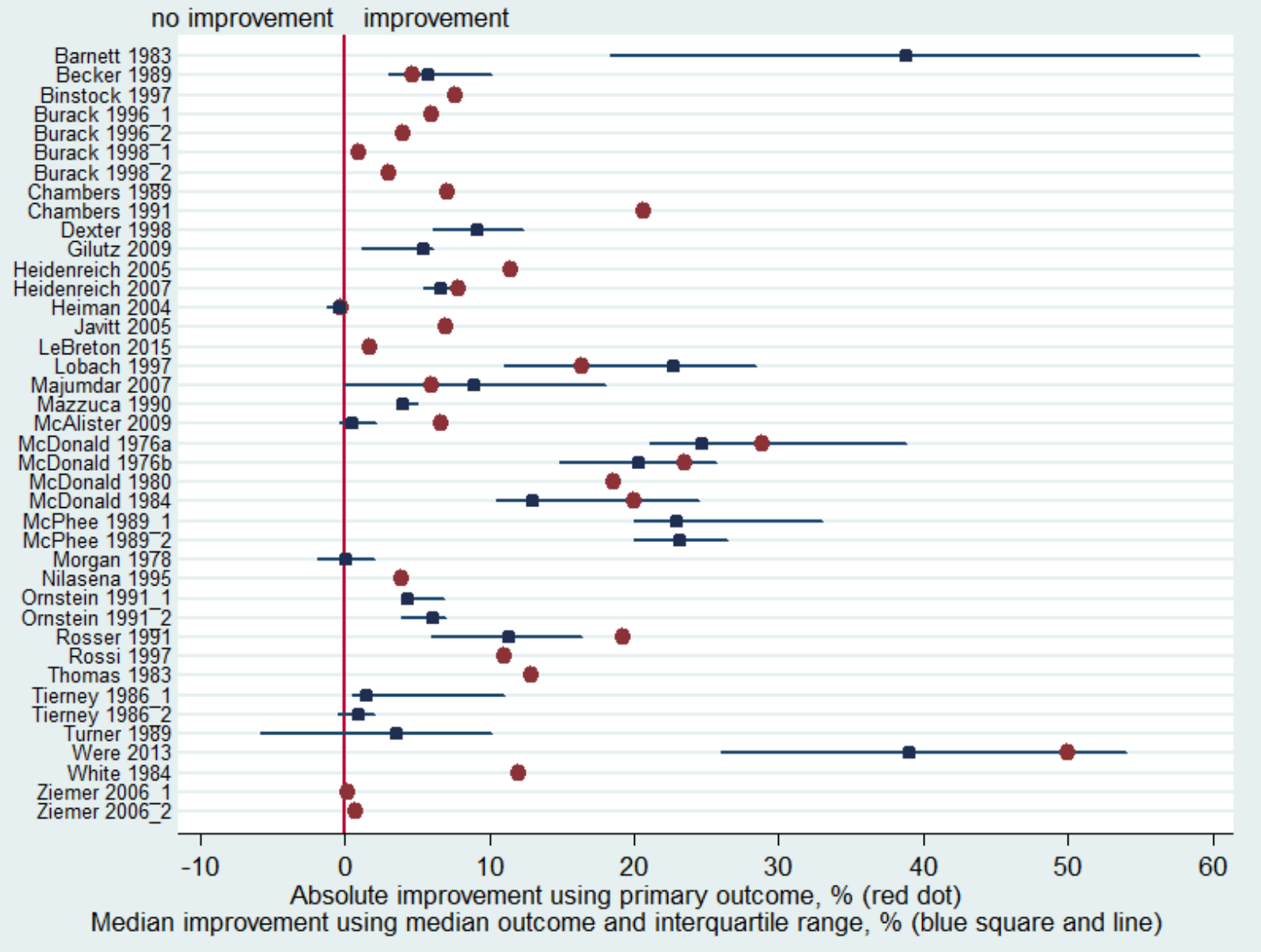

\section{Quality of care}

Computer-generated reminders delivered on paper to healthcare professionals, alone (single-component intervention) or in addition to co-intervention(s) (multi-component intervention), probably improve slightly quality of care compared with usual care or the co-intervention(s) without the reminder component (median improvement $6.8 \%$ (IQR: $3.8 \%$ to $17.5 \%$ ); 34 studies (40 comparisons); moderate-certainty evidence) (see Summary of findings for the main comparison).

Computer-generated reminders delivered on paper to healthcare professionals alone (single-component intervention) probably improves quality of care compared with usual care (median improvement $11.0 \%$ (IQR $5.4 \%$ to $20.0 \%$ ); 27 studies (27 comparisons); moderate-certainty evidence) (see Summary of findings 2). Adding computer-generated reminders delivered on paper to healthcare professionals to one or more co-interventions (multi-component intervention) probably improves quality of care slightly compared with the co-intervention(s) without the reminder component (median improvement $4.0 \%$ (IQR 3.0\% to $6.0 \%$ ); 11 studies (13 comparisons); moderate-certainty evidence) (see Summary of findings 3 ).
A possible explanation for the different magnitude of effect according to the presence of co-intervention(s) would be that co-interventions delivered to both groups leave little room for reminders to demonstrate additional improvement. Indeed, the median post-intervention quality of care rate in the additional intervention(s) alone control groups was higher than the rate in the usual care groups (median: $27.4 \%$ versus $21.8 \%$ ).

Of the 40 comparisons, 14 reported baseline quality of care rates for study groups. For these comparisons, the median marginal improvement in the intervention group (i.e. the improvement in the intervention group minus the improvement in the control group) was $3.9 \%$ (IQR $0.5 \%$ to $7 \%$ ).

\section{Subgroup analyses: impact of reminder features on quality of care effect size}

We examined the impact of a number of characteristics of the reminders on the magnitude of effect (Figure 5). Effect size was associated with three features: the availability of space for healthcare professionals to enter a response (median $13.7 \%$ versus $4.3 \%$ for no space, $\mathrm{P}=0.01$ ), reminders including an explanation of their content or advice (median $12.0 \%$ versus $4.2 \%$ for no explanation, $\mathrm{P}=0.02)$, and reminders explicitly from or justified by reference to an influential source (median $20.0 \%$ versus $5.4 \%$ for 
no reference, $P=0.04)$. The following reminder features were not associated: specific advice included in the reminder (median $6.1 \%$ versus $13.9 \%, \mathrm{P}=0.49$ ), and reminders available at point-of-care (median $7.1 \%$ versus $6.0 \%, \mathrm{P}=0.93$ ). The impact of whether the reminder was patient-specific or generic was not assessed, as only one study examined generic reminders.

Figure 5. Median effect and interquartile range (IQR) across comparisons by reminder feature ( $P$ values reflect Mann-Whitney test)

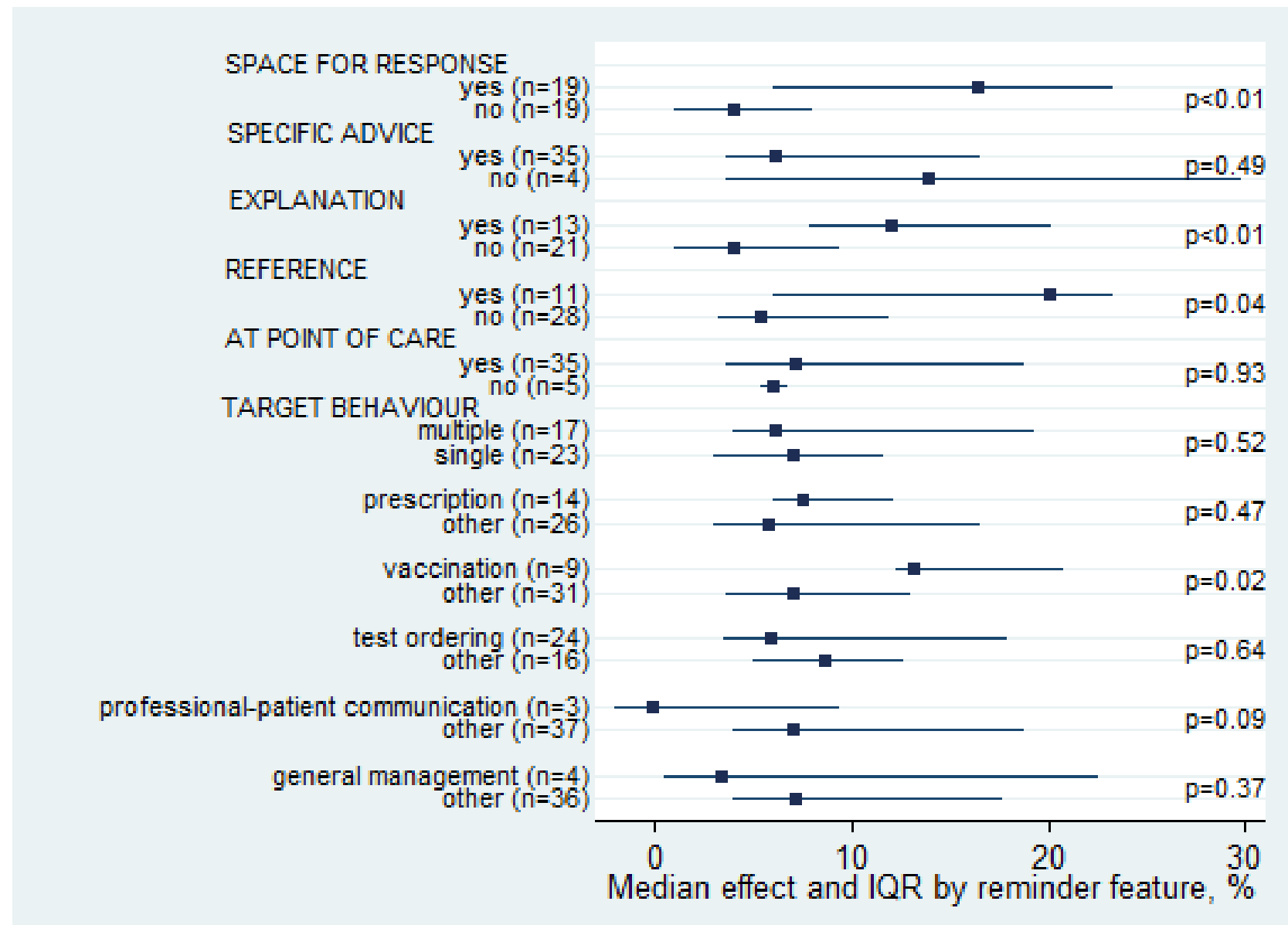

The median improvement in quality of care associated with reminders differed according to the targeted behavior but not the number of targeted behaviors. The largest improvement seen was in vaccination, with a median improvement of $13.1 \%$ (IQR $12.2 \%$ to $20.7 \%$ ), while the smallest improvement seen was for professionalpatient communication, with a median reduction of $-0.2 \%$ (IQR $-2 \%$ to $9.2 \%)$.

\section{Subgroup analyses: impact of study features on quality of care effect size}

There were sufficient comparisons to permit analyses of potential associations between various study features and the magnitude of effect (Figure 6). No association was found between effect size and study features, except for patient sample size. Studies with a small patient sample size achieved larger improvements than studies with a large patient sample size (median $11.8 \%$ versus $4.9 \%, \mathrm{P}=$ 0.05). 
Figure 6. Median effect and interquartile range (IQR) across comparisons by study feature ( ${ }^{\star}$ Kruskall-Wallis test; other $P$ values reflect Mann-Whitney test)

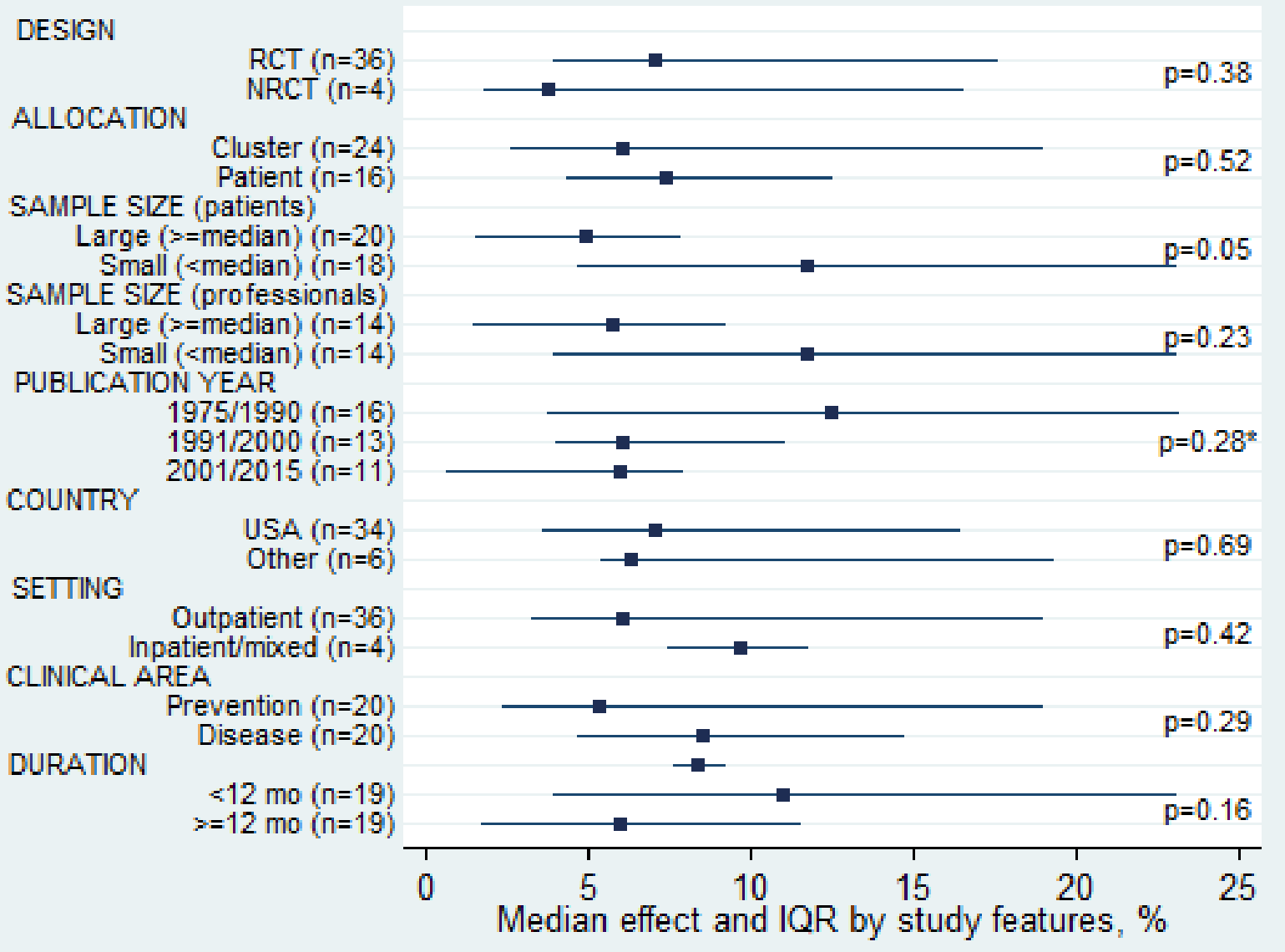

Studies published up to 1990 showed larger improvements than those published after 1990 (median $12.4 \%$ for up to $1990,6.1 \%$ for 1991 to 2000 and $6.0 \%$ for 2001 to $2015, P=0.28$ ). To determine whether this reflected temporal changes in baseline rates, we examined the baseline quality of care rates in the control and intervention groups in the 14 comparisons reporting baseline data; there was no temporal trend in either group. Baseline adherence rates were actually higher in the studies published before 1990 reporting baseline rates than in those published after 1990 . We also looked at the post-intervention quality of care rates in the control and intervention groups in all 40 comparisons, which were similar across the years.

Only the two cross-over studies (McDonald 1976a; McDonald 1980) examined quality of care after the end of the reminder delivery. Neither study showed a statistical carry-over effect of experimental effect into control periods.

\section{Subgroup analyses: disadvantaged populations}

The effect of provider reminders in settings serving disadvantaged and minority populations has been specifically evaluated in 10 studies. Eight studies took place in inner-cities in the USA, with high rates of African-American, economically disadvantaged, medicaid eligible and uninsured populations, aiming to improve preventive care rates (Becker 1989; Burack 1996; Burack 1998; Chambers 1989;
Chambers 1991; Ornstein 1991; Turner 1989) or to improve diabetes care (Ziemer 2006). In addition, the French study (Le Breton 2016) aimed to improve screening rates in a population where a quarter lived in socio-economically deprived areas and the Kenyan study (Were 2013) aimed to improve pediatric HIV care in a resourcelimited setting. The improvement of quality of care achieved with reminders in these studies with disadvantaged populations (median 4.2\%, IQR $1.7 \%$ to $6.1 \%$, 14 comparisons) was lower than the median improvement in studies not focusing on disadvantaged populations (median 10.3\%, IQR 5.4\% to 19.2\%, 26 comparisons), and the overall median improvement (median 6.8\%, IQR 3.8\% to $17.5 \%, 40$ comparisons). Also, the baseline quality of care rates in the studies in disadvantaged population $(19.5 \%$ in the control group and $21.8 \%$ in the intervention group, seven comparisons with baseline data) was lower than the baseline quality of care rates in the studies in general population $34.6 \%$ in the control group and $38.0 \%$ in the intervention group, seven comparisons with baseline data).

\section{Sensitivity analyses}

Similar median improvement of quality of care was observed when only studies with allocation concealment and complete outcome data were considered (median improvement: 6.8\%, IQR 3.9\% to 9.7\%) and when excluding the six studies with estimated data (median improvement: $5.0 \%$, IQR: $1.5 \%$ to $23.0 \%$ ). 
Table 2 shows the results obtained when we re-analyzed the median improvement of quality of care using the outcome with the largest improvement and the outcome with the smallest improvement for the representative outcome for each study, respectively. As expected, median improvement was larger when using the largest outcome and smaller when using the smallest outcome for all three comparisons. The IQR range included 0 in one comparison: when using the smallest outcome in the reminder with co-intervention comparison.

We also re-analyzed the impact of reminder and study features on effect size using the largest and smallest outcome for the representative outcome for each study. None of these analyses yielded substantially different findings compared with the findings using the primary (or median) outcome. The direction of the impact of the reminder and study features remained the same.

\section{Patient outcomes}

Six studies reported patient outcomes (see Table 3), but we were unable to pool them because of heterogeneity: they measured different clinical outcomes in different populations. In these studies, reminders had no measurable effect on i) blood pressure, glycated hemoglobin and cholesterol levels, ii) reaching blood pressure, glycated hemoglobin and cholesterol targets, and iii) mortality.

We are thus uncertain whether reminders, alone (singlecomponent intervention) or in addition to co-intervention(s) (multi-component intervention), improve patient outcomes compared with usual care or the co-intervention(s) without the reminder component as the certainty of the evidence is very low ( $n$ $=6$ studies (seven comparisons)) (see Summary of findings for the main comparison).

We are uncertain whether reminders alone improve patient outcomes compared with usual care ( $n=4$ studies (four comparisons), very low-certainty evidence) (see Summary of findings 2). We are also uncertain whether adding reminders to one or more co-interventions improve patient outcomes compared with the co-intervention(s) without the reminder component ( $\mathrm{n}=$ 2 studies (three comparisons), very low-certainty evidence) (see Summary of findings 3 ).

\section{Adverse effects}

None of the included studies reported outcomes related to harms or adverse effects of the intervention.

\section{DISCUSSION}

\section{Summary of main results}

Computer-generated reminders delivered on paper to healthcare professionals, alone or in addition to co-intervention(s), probably improve slightly quality of care compared with usual care or the co-intervention(s) without the reminder component (median improvement $6.8 \%$ (interquartile range (IQR): $3.8 \%$ to $17.5 \%$ ); 34 studies (40 comparisons); moderate-certainty evidence) (see Summary of findings for the main comparison).

Computer-generated reminders delivered on paper to healthcare professionals alone (single-component intervention) probably improve quality of care compared with usual care (median improvement $11.0 \%$ (IQR $5.4 \%$ to $20.0 \%$ ); 27 studies (27 comparisons); moderate-certainty evidence) (see Summary of findings 2). Adding computer-generated reminders delivered on paper to healthcare professionals to one or more co-interventions (multi-component intervention) probably improve slightly quality of care compared with the co-intervention(s) without the reminder component (median improvement $4.0 \%$ (IQR $3.0 \%$ to $6.0 \%$ ); 11 studies (13 comparisons); moderate-certainty evidence) (see Summary of findings 3 ).

We are uncertain whether reminders, alone or in addition to cointervention(s), improve patient outcomes compared with usual care or the co-intervention(s) without the reminder component because the certainty of the evidence is very low. None of the included studies reported outcomes related to harms or adverse effects of the intervention, such as redundant testing or overdiagnosis.

As the authors of the on-screen reminders have suggested (Shojania 2009), the lower improvement rate in multi-component interventions could be due to the improved quality of care achieved by the other components of the multi-component intervention, leaving less room for improvement by the reminder. Our analyses support this explanation as post-intervention compliance rates were higher in the multi-component intervention control group than the rate in the usual care group. An additional explanation offered by Shojania and colleagues might be that investigators chose to incorporate reminders in multi-component interventions when attempting to change more complex (and therefore difficult to change) behaviors than those addressed by reminders alone.

Three reminder features were associated with larger effect sizes: providing space for the provider to enter a response, providing an explanation for the reminder, and providing a reference to an influential source. Providing space for a response is likely to increase physician attention to the reminder. Indeed, in a study that specifically investigated this aspect (Litzelman 1993), requiring physicians to respond to reminders improved their overall compliance with cancer screening test by $8 \%$ compared with reminders that did not require a response $(P=0.002)$. Concerning the second feature, providing an explanation for the reminder may allow physicians to understand why they received a reminder and encourage them to respond to the reminder and not discard it. The third feature, providing a reference to an influential source, may further legitimate the reminder and convince the physician to follow the reminder.

Most studies focused on quality of care outcomes. Patient outcomes were most often secondary or non targeted outcomes in the individual studies. Only two of the 35 studies used an endpoint patient outcome (mortality, event-free survival), whereas four others used an intermediary patient outcome (blood pressure, laboratory tests). Although improving patient outcomes is the ultimate objective of any quality improvement intervention, showing or not showing an impact on patient outcome does not mean the intervention is not effective. The degree to which provider behavior changes ultimately improve patient outcomes will vary according to the strength of the relationship between the targeted process of interest and patient-level outcomes.

\section{Overall completeness and applicability of evidence}

The studies included in this review were conducted over the last 35 years. While three studies were executed as early as in

Computer-generated reminders delivered on paper to healthcare professionals: effects on professional practice and healthcare outcomes 
the 1970s, when computerized medical record systems started to be implemented in hospitals (McDonald 1976a; McDonald 1976b; Morgan 1978), most studies were performed in the 1980s and the 1990 s, when computerized databases became more widespread. Within the last 10 years, studies on computer-generated reminders delivered on paper continued to be conducted, parallel to studies on onscreen reminders. A review showed that reminders including a paper-based component remained the most frequent implementation strategy and had a similar average effect as computerized reminders (Dexheimer 2008). The paper record appears to remain an important source of information and documentation instrument in both hospitals and clinics. Paperbased solutions may indeed be easier to integrate with the clinical workflow, as compared with designing a completely computerized reminder that relies on the providers' workstation use. This same review showed however that studies on the impact of computer-generated reminders delivered on paper have tended to decrease, while computerized reminders have increased (Dexheimer 2008). This increase in computerized reminder strategies may suggest that clinical information systems are increasingly being adopted, providing the infrastructure to implement computerized reminders.

The effectiveness of reminders in improving patient outcomes could not be estimated because the few studies that reported outcomes of care, reported data too heterogenous to combine. Most studies measured whether reminders improved quality of care, i.e. intermediate outcomes, rather than improved patient outcomes, the ultimate goal of any quality improvement intervention.

Using the median effect across studies as effect size limits the interpretation of the results (precision of study effect size not taken into account). However, conventional methods of meta-analysis were not appropriate in our context, due to study heterogeneity and clustering effects that could not be taken into account in many studies failing to report the intra-class correlation. The median effect approach is increasingly used in Cochrane reviews (e.g. Farmer 2008; O'Brien 2007; Shojania 2009). This method allows for reporting on the range of effects associated with the intervention under study and allows for analysis of potential effect modifiers. Although we performed bivariate analyses, we were not able to perform multivariate analyses due to missing data on intervention details related to effect modifiers in many studies.

Studies included in this review were mostly carried out in outpatient settings, for preventive and chronic or acute care. While studies were exclusively based in the USA and Canada in the first publication of the review, the three studies added in this update were all based outside of North America (France, Israel, Kenya). Most studies were based in university hospitals, universityaffiliated clinics or large healthcare organizations (e.g. Veterans Health Administration, private Health Maintenance Orgnizations (HMO)), which often developed their own electronic medical record system and embedded reminder system (e.g. ComputerStored Ambulatory Record (COSTAR) developed at Massachusetts General Hospital for Harvard Community Health Plan, Regenstrief Medical Records System developed at the Indiana University School of Medicine). This limits the applicability of the evidence to other types of healthcare delivery systems. It appears that the improvement of quality of care achieved with reminders is more modest in studies targeting disadvantaged populations compared with studies targeting general populations. Also, the quality of care provided to disadvantaged populations before the reminder intervention was lower than the quality of care provided to the general population, among our included studies. Reminder interventions do not appear as beneficial in context of disadvantaged groups where access to care and out-of-pocket expenses, for instance, might be a stronger barrier to better quality of care than healthcare providers' behavior.

\section{Certainty of the evidence}

Overall, the certainty of the evidence regarding the effectiveness of computer-generated reminders delivered on paper to improve quality of care was rated as moderate according to the GRADE approach (see Summary of findings for the main comparison; Summary of findings 2; Summary of findings 3 ). We downgraded the level of certainty of the evidence from high to moderate because of methodological limitations of the included randomized trials. The quality of the studies was fairly low. One reason for the low quality of studies was that reporting of earlier studies was very poor, thus making it difficult to assess whether appropriate measures were taken to reduce bias. Actually, this may be the reason for the observed decreasing time trend in the size of the effect. In addition, as few studies reported baseline adherence rates, marginal improvement of reminders could not be correctly evaluated. The majority of studies did not implement nor report allocation concealment and appropriate analyses according to unit of allocation. Authors of approximately one half of studies (14) did report follow-up features allowing us to conclude that the risk for a potential attrition bias was low. We did not find other serious limitations in the other factors (indirectness of evidence, inconsistency of results, and imprecision of results).

The certainty of the evidence regarding the effectiveness of computer-generated reminders delivered on paper to improve patient outcomes was rated as very low according to the GRADE approach (see Summary of findings for the main comparison; Summary of findings 2; Summary of findings 3). We downgraded the level of certainty of the evidence from high to very low because of methodological limitations in the included randomized trials, wide variation of results (inconsistency) and wide confidence intervals (imprecision).

We can not rule out the presence of publication bias: smaller studies (in terms of included patients and healthcare professionals) showed greater effect size than larger studies (figures available on request). It is thus possible that smaller studies with negative or non-significant results were not published, further reducing the true overall effect size.

\section{Potential biases in the review process}

We conducted extensive literature searches including multiple databases with overlapping periods to avoid publication bias. Two people, working independently, screened all search results to minimize the risk of missing a relevant study. Study selection was discussed thoroughly to check whether the reminder system met the inclusion criteria. Using the median effect size as analytic approach allowed us to avoid the unit of analysis issues in unadjusted cluster trials, but it limits the interpretability of the results as there are no confidence intervals of individual effect sizes indicating the degree of imprecision of the results. 


\section{Agreements and disagreements with other studies or reviews}

There are a number of previous reviews on the effectiveness of reminders alone (e.g. Balas 2000; Baron 2010) or reminders as part of a multi-component intervention (e.g. Garg 2005; Grimshaw 2004), focusing on various types of reminders (e.g. computerized, manual). Compared with the median improvement in quality of care of $4.2 \%$ reported in the Cochrane systematic review of onscreen point-of-care computer reminders including 28 studies (Shojania 2009), the median improvement of $6.8 \%$ we observed in our review was only slightly higher. In a review comparing the effect of various intervention techniques for prompting physicians, the average rate difference for adherence to recommended preventive care strategies using computer- generated reminders did not differ from non-computerized prompting approaches (Balas 2000). We also observed that the largest improvement in quality of care was seen in vaccination rates, with a median improvement of $13.1 \%$. Similar rates were found in other systematic reviews focusing on vaccination and preventive care performance (Balas 2000; Baron 2010; Dexheimer 2008).

Regarding effect modifiers, unlike our review where we observed differences in effect according to whether the reminder provided space for the provider to enter a response, provided an explanation for the reminder, and provided a reference to an influential source, other systematic reviews found no specific reminder or contextual features significantly associated with effect magnitude (Baron 2010; Shojania 2009).

\section{AUTHORS' CONCLUSIONS}

\section{Implications for practice}

The findings of this review provide moderate evidence to support the use of computer-generated reminders delivered on paper to healthcare professionals to improve quality of care. Providing space on the reminder for a response from the clinician, providing an explanation of the reminder's content or advice, and providing a reference to an influential source were associated with larger effect sizes. The heterogeneity of the reminder interventions included in this review also suggests that reminders can be implemented in various settings for various health conditions.

\section{Implications for research}

To improve the quality of the rather mixed evidence base in this important area and address further policy-relevant questions, we suggest that researchers and research funders consider the following suggestions for future research on reminders.

- Better reporting of methods (for randomization, allocation concealment, etc.) in compliance with existing reporting standards, such as the CONSORT checklist (Moher 2010).

- Better reporting of quality improvement interventions (Hoffmann 2014; Ogrinc 2016) to allow better classification and comparisons of reminder features.

- Develop and apply better approaches, definitions, analyses and reporting of complex interventions (Craig 2008; Mohler 2015).

- Report quality of care and patient outcomes at baseline and at follow-up.

- Consider the probability, nature and process of contamination before designing the study. Cluster-randomization may or may not be appropriate and should not be uncritically assumed always to be a solution as it holds statistical disadvantage (larger sample size required) (Keogh-Brown 2007).

- If using a cluster design, use rigorous statistical methods and report all relevant data (Campbell 2007).

- Use blind assessment of outcomes to reduce assessment bias.

- Investigate the effectiveness of reminders in various healthcare delivery systems, outside North America and universityaffiliated hospitals.

- Investigate the learning effect of reminders (after the end of the intervention).

\section{ACKNOWLEDGEMENTS}

For this update, we would like to acknowledge the contribution of the following individuals who helped with data selection and extraction: Julia Worswick (JW), Sebastien Bacher (SB), and Sharlini Yogasingam (SY).

We would also like to acknowledge the support of the National Institute for Health Research (NIHR), via Cochrane Infrastructure funding to the Effective Practice and Organisation of Care (EPOC) Group, and the Ottawa Hospital Research Institute (OHRI) supporting JW and SY. The views and opinions expressed therein are those of the authors and do not necessarily reflect those of the Systematic Reviews Programme, NIHR, National Health Service (NHS), or the Department of Health.

We were unable to contact Jeremy Wyatt (co-author of the original version of the review) for this update. We acknowledge here his contribution to the original version of the review. 


\section{RE F E R E N C E S}

\section{References to studies included in this review}

\section{Barnett 1983 \{published data only\}}

Barnett GO, Winickoff RN, Morgan MM, Zielstorff RD. A computer-based monitoring system for follow-up of elevated blood pressure. Medical Care 1983;21(4):400-9.

\section{Becker 1989 \{published data only\}}

Becker DM, Gomez EB, Kaiser DL, Yoshihasi A, Hodge RH Jr. Improving preventive care at a medical clinic: how can the patient help?. American Journal of Preventive Medicine 1989;5(6):353-9.

\section{Binstock 1997 \{published data only\}}

Binstock MA, Geiger AM, Hackett JR, Yao JF. Pap smear outreach: a randomized controlled trial in an HMO. American Journal of Preventive Medicine 1997;13(6):425-6.

\section{Burack 1996 \{published data only\}}

Burack RC, Gimotty PA, George J, Simon MS, Dews P, Moncrease $A$. The effect of patient and physician reminders on use of screening mammography in a health maintenance organization. Results of a randomized controlled trial. Cancer 1996;78(8):1708-21.

\section{Burack 1998 \{published data only\}}

Burack RC, Gimotty PA, George J, McBride S, Moncrease A, Simon MS, et al. How reminders given to patients and physicians affected pap smear use in a health maintenance organization: results of a randomized controlled trial. Cancer 1998;82(12):2391-400.

\section{Chambers 1989 \{published data only\}}

Chambers CV, Balaban DJ, Carlson BL, Ungemack JA, Grasberger DM. Microcomputer-generated reminders. Improving the compliance of primary care physicians with mammography screening guidelines. Journal of Family Practice 1989;29(3):273-80

\section{Chambers 1991 \{published data only\}}

Chambers CV, Balaban DJ, Carlson BL, Grasberger DM. The effect of microcomputer-generated reminders on influenza vaccination rates in a university-based family practice center. Journal of the American Board of Family Practice 1991;4(1):19-26.

\section{Dexter 1998 \{published data only\}}

Dexter PR, Wolinsky FD, Gramelspacher GP, Zhou XH, Eckert GJ, Waisburd M, et al. Effectiveness of computer-generated reminders for increasing discussions about advance directives and completion of advance directive forms. A randomized, controlled trial. Annals of Internal Medicine 1998;128(2):102-10.

\section{Gilutz 2009 \{published data only\}}

Gilutz H, Novack L, Shvartzman P, Zelingher J, Bonneh DY, Henkin Y, et al. Computerized community cholesterol control (4C): meeting the challenge of secondary prevention. Israel Medical Association Journal 2009;11(1):23-9. [PUBMED: 19344008]
Heidenreich 2005 \{published data only\}

Heidenreich PA, Chacko M, Goldstein MK, Atwood JE. ACE inhibitor reminders attached to echocardiography reports of patients with reduced left ventricular ejection fraction. American Journal of Medicine 2005;118(9):1034-7.

Heidenreich 2007 \{published data only\}

Heidenreich PA, Gholami P, Sahay A, Massie B, Goldstein MK. Clinical reminders attached to echocardiography reports of patients with reduced left ventricular ejection fraction increase use of beta-blockers: a randomized trial. Circulation 2007;115(22):2829-34.

\section{Heiman 2004 \{published data only\}}

Heiman H, Bates DW, Fairchild D, Shaykevich S, Lehmann LS. Improving completion of advance directives in the primary care setting: a randomized controlled trial. American Journal of Medicine 2004;117(5):318-24.

Javitt 2005 \{published and unpublished data\}

Javitt JC, Steinberg G, Locke T, Couch JB, Jacques J, Juster I, et al. Using a claims data-based sentinel system to improve compliance with clinical guidelines: results of a randomized prospective study. American Journal of Managed Care 2005;11(2):93-102.

\section{Le Breton 2016 \{published data only\}}

Le Breton J, Ferrat E, Attali C, Bercier S, Le Corvoisier P, Brixi Z, et al. Effect of reminders mailed to general practitioners on colorectal cancer screening adherence: a cluster-randomized trial. European journal of cancer prevention : the official journal of the European Cancer Prevention Organisation (ECP) 2016;25(5):380-7. [PUBMED: 26340058]

\section{Lobach 1997 \{published data only\}}

* Lobach DF, Hammond WE. Computerized decision support based on a clinical practice guideline improves compliance with care standards. American Journal of Medicine 1997;102(1):89-98.

Lobach DF, Hammond WE. Development and evaluation of a Computer-Assisted Management Protocol (CAMP): improved compliance with care guidelines for diabetes mellitus. Proceedings / the Annual Symposium on Computer Applications in Medical Care 1994;-:787-91.

\section{Majumdar 2007 \{published data only\}}

Majumdar SR, McAlister FA, Tsuyuki RT. A cluster randomized trial to assess the impact of opinion leader endorsed evidence summaries on improving quality of prescribing for patients with chronic cardiovascular disease: rationale and design [ISRCTN26365328]. BMC Cardiovascular Disorders 2005;5(1):17.

* Majumdar SR, Tsuyuki RT, McAlister FA. Impact of opinion leader-endorsed evidence summaries on the quality of prescribing for patients with cardiovascular disease: a randomized controlled trial. American Heart Journal 2007;153(1):22.e1-8. 


\section{Mazzuca 1990 \{published data only\}}

Mazzuca SA, Vinicor F, Einterz RM, Tierney WM, Norton JA, Kalasinski LA. Effects of the clinical environment on physicians' response to postgraduate medical education. American Educational Research Journal 1990;27(3):473-88.

McAlister 2009 \{published data only\}

McAlister FA, Fradette M, Graham M, Majumdar SR, Ghali WA, Williams $\mathrm{R}$, et al. A randomized trial to assess the impact of opinion leader endorsed evidence summaries on the use of secondary prevention strategies in patients with coronary artery disease: the ESP-CAD trial protocol [NCT00175240]. Implementation Science 2006;1:11.

* McAlister FA, Fradette M, Majumdar SR, Williams R, Graham M, McMeekin J, et al. The enhancing secondary prevention in coronary artery disease trial. Canadian Medical Association Journal 2009;181(12):897-904.

\section{McDonald 1976a \{published data only\}}

McDonald CJ. Protocol-based computer reminders, the quality of care and the non-perfectability of man. New England Journal of Medicine 1976;295(24):1351-5.

\section{McDonald 1976b \{published data only\}}

McDonald CJ. Use of a computer to detect and respond to clinical events: its effect on clinician behavior. Annals of Internal Medicine 1976;84(2):162-7.

\section{McDonald 1980 \{published data only\}}

McDonald CJ, Wilson GA, McCabe GP Jr. Physician response to computer reminders. JAMA 1980;244(14):1579-81.

\section{McDonald 1984 \{published data only\}}

* McDonald CJ, Hui SL, Smith DM, Tierney WM, Cohen SJ, Weinberger $\mathrm{M}$, et al. Reminders to physicians from an introspective computer medical record. A two-year randomized trial. Annals of Internal Medicine 1984;100(1):130-8.

McDonald CJ, Hui SL, Tierney WM. Effects of computer reminders for influenza vaccination on morbidity during influenza epidemics. MD Computing 1992;9(5):304-12.

\section{McPhee 1989 \{published data only\}}

Bird JA, McPhee SJ, Jenkins C, Fordham D. Three strategies to promote cancer screening. How feasible is wide-scale implementation?. Medical Care 1990;28(11):1005-12.

Fordham D, McPhee SJ, Bird JA, Rodnick JE, Detmer WM. The Cancer Prevention Reminder System. MD Computing 1990; 7(5):289-95.

* McPhee SJ, Bird JA, Jenkins CN, Fordham D. Promoting cancer screening. A randomized, controlled trial of three interventions. Archives of Internal Medicine 1989;149(8):1866-72.

\section{Morgan 1978 \{published data only\}}

Morgan M, Studney DR, Barnett GO, Winickoff RN. Computerized concurrent review of prenatal care. QRB. Quality Review Bulletin 1978;4(9):33-6.

\section{Nilasena 1995 \{published data only\}}

* Nilasena DS, Lincoln MJ. A computer-generated reminder system improves physician compliance with diabetes preventive care guidelines. Proceedings / the Annual Symposium on Computer Applications in Medical Care. 1995:640-5.

Nilasena DS, Lincoln MJ, Turner CW, Warner HR, Foerster VA, Williamson JW, et al. Development and implementation of a computer-generated reminder system for diabetes preventive care. Proceedings / the Annual Symposium on Computer Application in Medical Care. 1994:831-5.

Oniki 2003 \{published data only\}

Oniki TA, Clemmer TP, Pryor TA. The effect of computergenerated reminders on charting deficiencies in the ICU. Journal of the American Medical Informatics Association 2003;10(2):177-87.

\section{Ornstein 1991 \{published data only\}}

Ornstein SM, Garr DR, Jenkins RG, Rust PF, Arnon A. Computergenerated physician and patient reminders. Tools to improve population adherence to selected preventive services. Journal of Family Practice 1991;32(1):82-90.

\section{Rosser 1991 \{published data only\}}

McDowell I, Newell C, Rosser W. A randomized trial of computerized reminders for blood pressure screening in primary care. Medical Care 1989;27(3):297-305.

McDowell I, Newell C, Rosser W. Comparison of three methods of recalling patients for influenza vaccination. Canadian Medical Association Journal 1986;135(9):991-7.

McDowell I, Newell C, Rosser W. Computerized reminders to encourage cervical screening in family practice. Journal of Family Practice 1989;28(4):420-4.

Rosser WW, Hutchison BG, McDowell I, Newell C. Use of reminders to increase compliance with tetanus booster vaccination. Canadian Medical Association Journal 1992;146(6):911-7.

* Rosser WW, McDowell I, Newell C. Use of reminders for preventive procedures in family medicine. Canadian Medical Association Journal 1991;145(7):807-14.

\section{Rossi 1997 \{published data only\}}

Rossi RA, Every NR. A computerized intervention to decrease the use of calcium channel blockers in hypertension. Journal of General Internal Medicine 1997;12(11):672-8.

\section{Thomas 1983 \{published data only\}}

Thomas JC, Moore A, Qualls PE. The effect on cost of medical care for patients treated with an automated clinical audit system. Journal of Medical Systems 1983;7(3):307-13.

\section{Tierney 1986 \{published data only\}}

Tierney WM, Hui SL, McDonald CJ. Delayed feedback of physician performance versus immediate reminders to perform preventive care. Effects on physician compliance. Medical Care 1986;24(8):659-66 


\section{Turner 1989 \{published data only\}}

Turner BJ. A controlled trial of strategies to improve delivery of preventive care. Research in medical education:proceedings of the annual Conference. Conference on Research in Medical Education 1987;26:9-13.

* Turner BJ, Day SC, Borenstein B. A controlled trial to improve delivery of preventive care: physician or patient reminders?. Journal of General Internal Medicine 1989;4(5):403-9.

Were 2013 \{published data only\}

Were MC, Nyandiko WM, Huang KT, Slaven JE, Shen C, Tierney WM, et al. Computer-generated reminders and quality of pediatric HIV care in a resource-limited setting. Pediatrics 2013;131(3):e789-96. [PUBMED: 23439898]

White 1984 \{published data only\}

White KS, Lindsay A, Pryor TA, Brown WF, Walsh K. Application of a computerized medical decision-making process to the problem of digoxin intoxication. Journal of the American College of Cardiology 1984;4(3):571-6.

\section{Ziemer 2006 \{published and unpublished data\}}

Phillips LS, Hertzberg VS, Cook CB, El-Kebbi IM, Gallina DL, Ziemer DC, et al. The Improving Primary Care of African Americans with Diabetes (IPCAAD) project: rationale and design. Controlled Clinical Trials 2002;23(5):554-69.

Phillips LS, Ziemer DC, Doyle JP, Barnes CS, Kolm P, Branch WT, et al. An endocrinologist-supported intervention aimed at providers improves diabetes management in a primary care site: improving primary care of African Americans with diabetes (IPCAAD). Diabetes Care 2005;28(10):2352-60.

* Ziemer DC, Doyle JP, Barnes CS, Branch WT Jr, Cook CB, ElKebbi IM, et al. An intervention to overcome clinical inertia and improve diabetes mellitus control in a primary care setting: Improving Primary Care of African Americans with Diabetes (IPCAAD). Archives of Internal Medicine 2006;166(5):507-13.

\section{References to studies excluded from this review}

\section{Adelman 2013 \{published data only\}}

Adelman JS, Kalkut GE, Schechter CB, Weiss JM, Berger MA, Reissman $\mathrm{SH}$, et al. Understanding and preventing wrongpatient electronic orders: a randomized controlled trial. Journal of the American Medical Informatics Association: JAMIA 2013;20(2):305-10.

\section{Alfadda 2011 \{published data only\}}

Alfadda AA, Bin-Abdulrahman KA, Saad HA, Mendoza CDO, Angkaya-Bagayawa FF, Yale JF. Effect of an intervention to improve the management of patients with diabetes in primary care practice. Saudi Medical Journal 2011;32(1):36-40.

\section{Anabtawi 2013 \{published data only\}}

Anabtawi A, Mathew LM. Improving compliance with screening of diabetic patients for microalbuminuria in primary care practice. ISRN Endocrinology 2013;2013:893913. [PUBMED: 24224095]

\section{Anchala 2012 \{published data only\}}

Anchala R, Pant H, Prabhakaran D, Franco OH. 'Decision support system (DSS) for prevention of cardiovascular disease (CVD) among hypertensive (HTN) patients in Andhra Pradesh, India'-a cluster randomised community intervention trial. BMC Public Health 2012;12:393. [PUBMED: 22650767]

Barkun 2013 \{published data only\}

Barkun AN, Bhat M, Armstrong D, Dawes M, Donner A, Enns R, et al. Effectiveness of disseminating consensus management recommendations for ulcer bleeding: a cluster randomized trial. CMAJ: Canadian Medical Association Journal 2013;185(3):E156-66.

\section{Barnes 2014 \{published data only\}}

Barnes ER, Theeke LA, Mallow J. Impact of the Provider and Healthcare team Adherence to Treatment Guidelines (PHAT-G) intervention on adherence to national obesity clinical practice guidelines in a primary care centre. Journal of Evaluation in Clinical Practice 2014;21(2):300-6.

\section{Beeckman 2013 \{published data only\}}

Beeckman D, Clays E, Van Hecke A, Vanderwee K, Schoonhoven L, Verhaeghe S. A multi-faceted tailored strategy to implement an electronic clinical decision support system for pressure ulcer prevention in nursing homes: a two-armed randomized controlled trial. Internation Journal of Nursing Studies 2013;50(4):475-86.

\section{Beeler 2014 \{published data only\}}

Beeler PE, Eschmann E, Schumacher A, Studt JD, AmannVesti B, Blaser J. Impact of electronic reminders on venous thromboprophylaxis after admissions and transfers. Journal of the American Medical Informatics Association: JAMIA 2014;21(e2):e297-303.

\section{Belland 2014 \{published data only\}}

Belland L, Rivera-Reyes L, Genes N, Thum F, Winkel G, Soriano J, et al. The effect of a novel clinical decision support system on pain care for older adults presenting to the emergency department with acute abdominal pain. Annals of Emergency Medicine. 2014; Vol. 64, issue 4:S81.

\section{Beste 2015 \{published data only\}}

Beste LA, loannou GN, Yang Y, Chang MF, Ross D, Dominitz JA. Improved surveillance for hepatocellular carcinoma with a primary care-oriented clinical reminder. Clinical Gastroenterology and Hepatology: the official clinical practice journal of the American Gastroenterological Association 2015;13(1):172-9. [PUBMED: 24813175]

Braun 2013 \{published data only\}

Braun R, Barandas A, Hancock-Crear A. Improving access and addressing barriers to HPV vaccination for adolescents and young adults. Contraception. 2013; Vol. 88, issue 2:307.

\section{Campbell 2014 \{published data only\}}

Campbell F, Peleshok J, Yamada J, Krancevic A-M, Pepper J, Dhaliwal M, et al. Impact of a quality improvement strategy for improving pain outcomes in a pediatric hospital setting. Pain Research and Management. 2014; Vol. 19, issue 3:e31.

Computer-generated reminders delivered on paper to healthcare professionals: effects on professional practice and healthcare outcomes 


\section{Carroll 2013 \{published data only\}}

Carroll AE, Biondich P, Anand V, Dugan TM, Downs SM. A randomized controlled trial of screening for maternal depression with a clinical decision support system. Journal of the American Medical Informatics Association: JAMIA 2013;20(2):311-6.

\section{Chen 2013 \{published data only\}}

Chen YY, Chi MM, Chen YC, Chan YJ, Chou SS, Wang FD. Using a criteria-based reminder to reduce use of indwelling urinary catheters and decrease urinary tract infections. American Journal of Critical Care 2013; Vol. 22, issue 2:105-14.

\section{Dexheimer 2013 \{published data only\}}

Dexheimer JW, Abramo TJ, Arnold DH, Johnson KB, Shyr Y, Ye F, et al. An asthma management system in a pediatric emergency department. International Journal of Medical Informatics 2013;82(4):230-8.

\section{Divinskiy 2015 \{published data only\}}

Divinskiy T, Nemytova E, Liu X, Ajmal S. A quality improvement project increased documentation of advance directives among an older population in a primary care setting. Annual Scientific Meeting of the American Geriatrics Society. 2015:63.

\section{dos Santos 2014 \{published data only\}}

dos Santos MA, Tygesen H, Eriksson H, Herlitz J. Clinical decision support system (CDSS)--effects on care quality. International Journal of Health Care Quality Assurance 2014;27(8):707-18.

\section{Erlingsdottir 2015 \{published data only\}}

Erlingsdottir H, Johannesson A, Asgeirsdottir TL. Can physician laboratory-test requests be influenced by interventions? Scandinavian Journal of Clinical and Laboratory Investigation 2015;75(1):18-26.

\section{Federman 2014 \{published data only\}}

Federman DG, Kravetz JD, Lerz KA, Akgun KM, Ruser C, Cain H, et al. Implementation of an electronic clinical reminder to improve rates of lung cancer screening. American Journal of Medicine 2014;127(9):813-6.

\section{Gifford 2013 \{published data only\}}

Gifford WA, Davies BL, Graham ID, Tourangeau A, Woodend AK, Lefebre N. Developing leadership capacity for guideline use: a pilot cluster randomized control trial. Worldviews on EvidenceBased Nursing 2013;10(1):51-65.

\section{Goldstein 2014 \{published data only\}}

Goldstein NE, Kalman J, Kutner JS, Fromme EK, Hutchinson MD, Lipman $\mathrm{HI}$, et al. A study to improve communication between clinicians and patients with advanced heart failure: Methods and challenges behind the working to improve discussions about defibrillator management trial. Journal of Pain and Symptom Management 2014;48(6):1236-46.

\section{Green 2014 \{published data only\}}

Green BB, Anderson ML, Wang C-Y, Vernon SW, Chubak J, Meenan RT, et al. Results of nurse navigator follow-up after positive colorectal cancer screening test: A randomized trial. Journal of the American Board of Family Medicine 2014;27(6):789-95.

\section{Gupta 2014 \{published data only\}}

Gupta A, Gholami P, Turakhia MP, Friday K, Heidenreich PA. Clinical reminders to providers of patients with reduced left ventricular ejection fraction increase defibrillator referral: a randomized trial. Circulation Heart Failure 2014;7(1):140-5.

\section{Hendrix 2015 \{published data only\}}

Hendrix KS, Downs SM, Carroll AE. Pediatricians' responses to printed clinical reminders: does highlighting prompts improve responsiveness?. Academic Pediatrics 2015;15(2):158-64.

\section{Hye 2014 \{published data only\}}

Hye RJ, Smith AE, Wong GH, Vansomphone SS, Scott RD, Kanter MH. Leveraging the electronic medical record to implement an abdominal aortic aneurysm screening program. Journal of Vascular Surgery 2014;59(6):1535-42.

\section{Jansink 2013 \{published data only\}}

Jansink R, Braspenning J, Keizer E, van der Weijden T, Elwyn G, Grol R. No identifiable Hb1Ac or lifestyle change after a comprehensive diabetes programme including motivational interviewing: a cluster randomised trial. Scandinavian Journal of Primary Health Care 2013;31(2):119-27.

\section{Kennedy 2012 \{published data only\}}

Kennedy CC, loannidis G, Giangregorio LM, Adachi JD, Thabane L, Morin SN, et al. An interdisciplinary knowledge translation intervention in long-term care: study protocol for the vitamin D and osteoporosis study (Original Title; URL links to DARE Abstract) pilot cluster randomized controlled trial. Implementation Science 2012;7:48.

\section{Kousgaard 2013 \{published data only\}}

Kousgaard MB, Siersma V, Reventlow S, Ertmann R, Felding P, Waldorff FB. The effectiveness of computer reminders for improving quality assessment for point-of-care testing in general practice--a randomized controlled trial. Implementation Science 2013;8:47.

\section{Lai 2015 \{published data only\}}

Lai CL, Chan HY, Pan YJ, Chen CH. The effectiveness of a computer reminder system for laboratory monitoring of metabolic syndrome in schizophrenic outpatients using secondgeneration antipsychotics. Pharmacopsychiatry 2015;48(1):25-9.

\section{Levy 2013 \{published data only\}}

Levy BT, Xu Y, Daly JM, Ely JW. A randomized controlled trial to improve colon cancer screening in rural family medicine: an lowa Research Network (IRENE) study. Journal of the American Board of Family Medicine 2013;26(5):486-97.

Lusignan 2013 \{published data only\}

de Lusignan S, Gallagher H, Jones S, Chan T, van Vlymen J, Tahir A, et al. Audit-based education lowers systolic blood pressure in chronic kidney disease: the Quality Improvement in CKD (QICKD) trial results. Kidney International 2013;84(3):609-20.

Computer-generated reminders delivered on paper to healthcare professionals: effects on professional practice and healthcare outcomes 
Lynn 2013 \{published data only\}

Lynn LA, Guerra CE, Ross KM, Holmboe E, Woo K, Heitjan DF, et al. A randomized controlled trial of an evidence-based toolbox and guide to increase primary care clinicians' rates of colorectal cancer screening in diplomates of the ABIM. Journal of General Internal Medicine. 2013; Vol. 28, issue Suppl 1.

\section{Majumdar 2012 \{published data only\}}

Majumdar SR, McAlister FA, Johnson JA, Bellerose D, Siminoski K, Hanley DA, et al. Interventions to increase osteoporosis treatment in patients with 'incidentally' detected vertebral fractures. American Journal of Medicine 2012;125(9):929-36.

\section{Maximov 2013 \{published data only\}}

Maximov D, Lesnyak O. Implementation of the osteoarthritis clinical guideline: Results of a cluster randomized trial in primary care. Annals of the Rheumatic Diseases. 2013; Vol. 71:307-8.

\section{McEvoy 2014 \{published data only\}}

McEvoy MD, Hand WR, Stoll WD, Furse CM, Nietert PJ. Adherence to guidelines for the management of local anesthetic systemic toxicity is improved by an electronic decision support tool and designated "Reader". Regional Anesthesia 2014;39(4):299-305.

\section{McNulty 2014 \{published data only\}}

McNulty CA, Hogan AH, Ricketts EJ, Wallace L, Oliver I, Campbell R, et al. Increasing chlamydia screening tests in general practice: a modified Zelen prospective Cluster Randomised Controlled Trial evaluating a complex intervention based on the Theory of Planned Behaviour. Sexually Transmitted Infections 2014;90(3):188-94. [PUBMED: 24005256]

\section{Melo 2013 \{published data only\}}

Melo Rodrigues R, Fontes AMS, Cesar Mantese O, Souza Martins R, Tanus Jorge M. Impact of an intervention in the use of sequential antibiotic therapy in a Brazilian university hospital. Revista da Sociedade Brasileira de Medicina Tropical 2013;46(1):50-4.

\section{Neal 2012 \{published data only\}}

Neal JM, Hsiung RL, Mulroy MF, Halpern BB, Dragnich AD, Slee AE. ASRA checklist improves trainee performance during a simulated episode of local anesthetic systemic toxicity. Regional Anesthesia and Pain Medicine 2012;37(1):8-15.

\section{Nguyen 2014 \{published data only\}}

Nguyen MC, Richardson DM, Hardy SG, Cookson RM, Mackenzie RS, Greenberg MR, et al. Computer-based reminder system effectively impacts physician documentation. American Journal of Emergency Medicine 2014;32(1):104-6.

\section{O'Reilly 2012 \{published data only\}}

O'Reilly D, Holbrook A, Blackhouse G, Troyan S, Goeree R. Cost-effectiveness of a shared computerized decision support system for diabetes linked to electronic medical records. Journal of the American Medical Informatics Association: JAMIA 2012;19(3):341-5.

\section{Persell 2016 \{published data only\}}

Persell SD, Doctor JN, Friedberg MW, Meeker D, Friesema E, Cooper A, et al. Behavioral interventions to reduce inappropriate antibiotic prescribing: a randomized pilot trial. BMC Infectious Diseases 2016;16:373. [PUBMED: 27495917]

Piazza 2013 \{published data only\}

Piazza G, Anderson FA, Ortel TL, Cox MJ, Rosenberg DJ, Rahimian S, et al. Randomized trial of physician alerts for thromboprophylaxis after discharge. American Journal of Medicine 2013;126(5):435-42.

\section{Roy 2016 \{published data only\}}

Roy PM, Rachas A, Meyer G, Le Gal G, Durieux P, El Kouri D, et al. Multifaceted Intervention to Prevent Venous Thromboembolism in Patients Hospitalized for Acute Medical Illness: A Multicenter Cluster-Randomized Trial. PloS One 2016;11(5):e0154832. [PUBMED: 27227406]

\section{Schwalm 2015 \{published data only\}}

Schwalm JD, Ivers NM, Natarajan MK, Taljaard M, RaoMelacini P, Witteman $\mathrm{HO}$, et al. Cluster randomized controlled trial of Delayed Educational Reminders for Long-term Medication Adherence in ST-Elevation Myocardial Infarction (DERLA-STEMI). American Heart Journal 2015;170(5):903-13. [PUBMED: 26542498]

\section{Siersma 2015 \{published data only\}}

Siersma V, Kousgaard MB, Reventlow S, Ertmann R, Felding P, Waldorff FB. The effectiveness of computer reminders versus postal reminders for improving quality assessment for pointof-care testing in primary care: a randomized controlled trial. Journal of Evaluation in Clinical Practice 2015;21(1):13-20.

\section{Stockwell 2015 \{published data only\}}

Stockwell MS, Catallozzi M, Camargo S, Ramakrishnan R, Holleran S, Findley SE, et al. Registry-linked electronic influenza vaccine provider reminders: a cluster-crossover trial. Pediatrics 2015;135(1):e75-82.

\section{Szilagyi 2015 \{published data only\}}

Szilagyi PG, Serwint JR, Humiston SG, Rand CM, Schaffer S, Vincelli $P$, et al. Effect of provider prompts on adolescent immunization rates: a randomized trial. Academic Pediatrics 2015;15(2):149-57.

\section{Tartaglia 2013 \{published data only\}}

Tartaglia KM, Walker C, Heacock A, Kuofie I, Liston B, West J, et al. Antibiotic timeout program: Implementing a hospital stewardship intervention. Journal of General Internal Medicine 2013;28:S429-30.

\section{Tedja 2014 \{published data only\}}

Tedja R, Hassebroek E, Carrera P, Thakur L, Mielke C, Volkman T, et al. Reducing urinary catheter days and utilization in a chronic ventilator dependent unit: Mayo clinic quality improvement experience. Chest 2014;146:556A.

Teoh 2012 \{published data only\}

Teoh L, Latif M, Choi P, Wu S, Chan CY, Plowman G, et al. Use of a reminder sticker improves rates of documentation of

Computer-generated reminders delivered on paper to healthcare professionals: effects on professional practice and healthcare outcomes 
resuscitation status and the appropriate prescription of venous thromboembolism prophylaxis. New Zealand Medical Journal 2012;125(1357):175-7.

\section{Weiss 2013 \{published data only\}}

Weiss CH, Dibardino D, Rho J, Sung N, Collander B, Wunderink RG. A clinical trial comparing physician prompting with an unprompted automated electronic checklist to reduce empirical antibiotic utilization. Critical Care Medicine 2013;41(11):2563-9.

\section{Were 2011 \{published data only\}}

Were MC, Shen C, Tierney WM, Mamlin JJ, Biondich PG, Li X, et al. Evaluation of computer-generated reminders to improve CD4 laboratory monitoring in sub-Saharan Africa: a prospective comparative study. Journal of the American Medical Informatics Association : JAMIA 2011;18(2):150-5. [PUBMED: 21252053]

\section{Additional references}

\section{Anderson 2007}

Anderson JG. Social, ethical and legal barriers to e-health. International Journal of Medical Informatics 2007;76(5-6):480-3. [PUBMED: 17064955]

\section{Axt-Adam 1993}

Axt-Adam P, van der Wouden JC, van der Does E. Influencing behavior of physicians ordering laboratory tests: a literature study. Medical Care 1993;31:784-94.

\section{Baker, 2015}

Baker R, Camosso-Stefinovic J, Gillies C, Shaw EJ, Cheater F, Flottorp S, et al. Tailored interventions to address determinants of practice. Cochrane Database of Systematic Reviews 2015, Issue 4. [DOI: 10.1002/14651858.CD005470.pub3]

\section{Balas 2000}

Balas EA, Weingarten S, Garb CT, Blumenthal D, Boren SA Brown GD. Improving preventive care by prompting physicians. Archives of Internal Medicine 2000;160(3):301-8. [PUBMED: 10668831]

\section{Balas 2004}

Balas EA, Krishna S, Kretschmer RA, Cheek TR, Lobach DF, Boren SA. Computerized knowledge management in diabetes care. Medical Care 2004;42(6):610-21. [PUBMED: 15167329]

\section{Baron 2010}

Baron RC, Melillo S, Rimer BK, Coates RJ, Kerner J, Habarta N, et al. Intervention to increase recommendation and delivery of screening for breast, cervical, and colorectal cancers by healthcare providers a systematic review of provider reminders. American Journal of Preventive Medicine 2010;38(1):110-7. [PUBMED: 20117566]

\section{Bennett 2003}

Bennett JW, Glasziou PP. Computerised reminders and feedback in medication management: a systematic review of randomised controlled trials. Medical Journal of Australia 2003;178(5):217-22. [PUBMED: 12603185]

\section{Biau 2008}

Biau DJ, Porcher R, Boutron I. The account for provider and center effects in multicenter interventional and surgical randomized controlled trials is in need of improvement: a review. Journal of Clinical Epidemiology 2008;61(5):435-9. [PUBMED: 18394535]

\section{Buntinx 1993}

Buntinx F, Winkens R, Grol R, Knottnerus JA. Influencing diagnostic and preventive performance in ambulatory care by feedback and reminders. A review. Family Practice 1993;10(2):219-28.

\section{Campbell 2007}

Campbell MJ, Donner A, Klar N. Developments in cluster randomized trials and Statistics in Medicine. Statistics in Medicine 2007;26(1):2-19. [PUBMED: 17136746]

\section{Craig 2008}

Craig P, Dieppe P, Macintyre S, Michie S, Nazareth I, Petticrew M. Developing and evaluating complex interventions: the new Medical Research Council guidance. BMJ (Clinical Research ed.) 2008;337:a1655. [PUBMED: 18824488]

\section{Davis 1992}

Davis DA, Thomson MA, Oxman AD, Haynes RB. Evidence for the effectiveness of CME. A review of 50 randomized controlled trials. JAMA 1992;268(9):1111-7.

\section{Davis 1995}

Davis DA, Thomson MA, Oxman AD, Haynes RB. Changing physician performance. A systematic review of the effect of continuing medical education strategies. JAMA 1995;274(9):700-5

\section{Dexheimer 2008}

Dexheimer JW, Talbot TR, Sanders DL, Rosenbloom ST, Aronsky D. Prompting clinicians about preventive care measures: a systematic review of randomized controlled trials. Journal of the American Medical Informatics Association 2008;15(3):311-20. [PUBMED: 18308989]

\section{EPOC 2015a}

Effective Practice, Organisation of Care (EPOC). Suggested risk of bias criteria for EPOC reviews. epoc.cochrane.org/epocspecific-resources-review-authors. Oslo: Norwegian Knowledge Centre for the Health Services, (accessed 1 July 2016).

\section{EPOC 2015b}

Effective Practice, Organisation of Care (EPOC). What study designs should be included in an EPOC review and what should they be called?. epoc.cochrane.org/epoc-specific-resourcesreview-authors. Oslo: Norwegian Knowledge Centre for the Health Services, (accessed 1 July 2016).

\section{EPOC 2015C}

Effective Practice, Organisation of Care (EPOC). Worksheets for preparing Summary of Findings tables using GRADE. epoc.cochrane.org/epoc-specific-resources-review-authors. Oslo: Norwegian Knowledge Centre for the Health Services, (accessed 1 July 2016). 


\section{EPOC 2015d}

Effective Practice, Organisation of Care (EPOC). What outcomes should be reported in EPOC reviews?. epoc.cochrane.org/epocspecific-resources-review-authors. Oslo: Norwegian Knowledge Centre for the Health Services, (accessed 1 July 2016).

\section{Fiander 2015}

Fiander M, McGowan J, Grad R, Pluye P, Hannes K, Labrecque $M$, et al. Interventions to increase the use of electronic health information by healthcare practitioners to improve clinical practice and patient outcomes. Cochrane Database of Systematic Reviews 2015, Issue 3. [DOI: 10.1002/14651858.CD004749.pub3]

\section{Flodgren 2011}

Flodgren G, Parmelli E, Doumit G, Gattellari M, O'Brien MA, Grimshaw J, et al. Local opinion leaders: effects on professional practice and health care outcomes. Cochrane Database of Systematic Reviews 2011, Issue 8. [DOI: 10.1002/14651858.CD000125.pub4]

\section{Forsetlund 2009}

Forsetlund L, Bjorndal A, Rashidian A, Jamtvedt G, O'Brien MA, Wolf $F$, et al. Continuing education meetings and workshops: effects on professional practice and health care outcomes. Cochrane Database of Systematic Reviews 2009, Issue 2. [DOI: 10.1002/14651858.CD003030.pub2]

\section{Gagnon 2009}

Gagnon MP, Legare F, Labrecque M, Fremont P, Pluye P, Gagnon J, et al. Interventions for promoting information and communication technologies adoption in healthcare professionals. Cochrane Database of Systematic Reviews 2009, Issue 1. [DOI: 10.1002/14651858.CD006093.pub2]

\section{Garg 2005}

Garg AX, Adhikari NK, McDonald H, Rosas-Arellano MP, Devereaux PJ, Beyene J, et al. Effects of computerized clinical decision support systems on practitioner performance and patient outcomes: a systematic review. JAMA 2005;293(10):1223-38. [PUBMED: 15755945]

\section{Giguère 2012}

Giguère A, Légaré F, Grimshaw J, Turcotte $S$, Fiander M, Grudniewicz A, et al. Printed educational materials: effects on professional practice and healthcare outcomes. Cochrane Database of Systematic Reviews 2012, Issue 10. [DOI: 10.1002/14651858.CD004398.pub3]

\section{GRADEpro GDT 2015 [Computer program]}

GRADE Working Group, McMaster University. GRADEpro GDT. Version accessed 10 August 2015. Hamilton (ON): GRADE Working Group, McMaster University, 2014.

\section{Grimshaw 2004}

Grimshaw JM, Thomas RE, MacLennan G, Fraser C, Ramsay CR, Vale $L$, et al. Effectiveness and efficiency of guideline dissemination and implementation strategies. Health Technology Assessment (Winchester, England) 2004;8(6):iii-iv, 1-72. [PUBMED: 14960256]

\section{Guyatt 2011}

Guyatt GH, Oxman AD, Schunemann HJ, Tugwell P, Knottnerus A. GRADE guidelines: a new series of articles in the Journal of Clinical Epidemiology. Journal of Clinical Epidemiology 2011;64(4):380-2. [PUBMED: 21185693]

\section{Haynes 1987}

Haynes RB, Walker CJ. Computer-aided quality assurance. A critical appraisal. Archives of Internal Medicine 1987;147(7):1297-301.

\section{Higgins 2011}

Higgins, JPT, Green, S. Cochrane Handbook for Systematic Reviews of Interventions Version. Version 5.1.0. Cochrane Handbook for Systematic Reviews of Interventions. Chichester: John Wiley \& Sons, 2011.

\section{Hoffmann 2014}

Hoffmann TC, Glasziou PP, Boutron I, Milne R, Perera R, Moher D, et al. Better reporting of interventions: template for intervention description and replication (TIDieR) checklist and guide. BMJ (Clinical Research ed.) 2014;348:g1687. [PUBMED: 24609605]

\section{Hunt 1998}

Hunt DL, Haynes RB, Hanna SE, Smith K. Effects of computerbased clinical decision support systems on physician performance and patient outcomes: a systematic review. JAMA 1998;280(15):1339-46. [PUBMED: 9794315]

\section{Ivers 2012}

Ivers N, Jamtvedt G, Flottorp S, Young JM, OdgaardJensen J, French SD, et al. Audit and feedback: effects on professional practice and healthcare outcomes. Cochrane Database of Systematic Reviews 2012;6:CD000259. [DOI: 10.1002/14651858.CD000259.pub3]

\section{Jha 2009}

Jha AK, DesRoches CM, Campbell EG, Donelan K, Rao SR, Ferris TG, et al. Use of electronic health records in U.S. hospitals. The New England Journal of Medicine 2009;360(16):1628-38. [PUBMED: 19321858]

\section{Johnston 1994}

Johnston ME, Langton KB, Haynes RB, Mathieu A. Effects of computer-based clinical decision support systems on clinician performance and patient outcome. Annals of Internal Medicine 1994;120(2):135-42.

\section{Kahan 2013}

Kahan BC, Morris TP. Assessing potential sources of clustering in individually randomised trials. BMC Medical Research Methodology 2013;13:58. [PUBMED: 23590245]

\section{Kawamoto 2005}

Kawamoto K, Houlihan CA, Balas EA, Lobach DF. Improving clinical practice using clinical decision support systems: a systematic review of trials to identify features critical to success. BMJ 2005;330(7494):765. [PUBMED: 15767266] 


\section{Keogh-Brown 2007}

Keogh-Brown MR, Bachmann MO, Shepstone L, Hewitt C, Howe A, Ramsay CR, et al. Contamination in trials of educational interventions. Health Technology Assessment (Winchester, England) 2007;11(43):iii, ix-107. [PUBMED: 17935683]

\section{Litzelman 1993}

Litzelman DK, Dittus RS, Miller ME, Tierney WM. Requiring physicians to respond to computerized reminders improves their compliance with preventive care protocols. Journal of General Internal Medicine 1993;8(6):311-7.

\section{Mahmud 2010}

Mahmud N, Rodriguez J, Nesbit J. A text message-based intervention to bridge the healthcare communication gap in the rural developing world. Technology and Health Care : official journal of the European Society for Engineering and Medicine 2010;18(2):137-44. [PUBMED: 20495253]

\section{Mandelblatt 1995}

Mandelblatt J, Kanetsky PA. Effectiveness of interventions to enhance physician screening for breast cancer. Journal of Family Practice 1995;40(2):162-71.

\section{McDonald 1976}

McDonald CJ. Protocol-based computer reminders, the quality of care and the non-perfectability of man. New England Journal of Medicine 1976;295(24):1351-5.

\section{Moher 2010}

Moher D, Hopewell S, Schulz KF, Montori V, Gotzsche PC, Devereaux PJ, et al. CONSORT 2010 explanation and elaboration: updated guidelines for reporting parallel group randomised trials. BMJ 2010;340:c869. [PUBMED: 20332511]

\section{Mohler 2015}

Mohler R, Kopke S, Meyer G. Criteria for Reporting the Development and Evaluation of Complex Interventions in healthcare: revised guideline (CReDECI 2). Trials 2015;16:204. [PUBMED: 25935741]

\section{Mollon 2009}

Mollon B, Chong J Jr, Holbrook AM, Sung M, Thabane L, Foster $\mathrm{G}$. Features predicting the success of computerized decision support for prescribing: a systematic review of randomized controlled trials. BMC Medical Informatics and Decision Making 2009;9:11. [PUBMED: 19210782]

\section{Morris 2002}

Morris AH. Decision support and safety of clinical environments. Quality \& Safety in Health Care 2002;11(1):69-75. [PUBMED: 12078374]

\section{Ndiaye 2005}

Ndiaye SM, Hopkins DP, Shefer AM, Hinman AR, Briss PA, Rodewald $L$, et al. Interventions to improve influenza, pneumococcal polysaccharide, and hepatitis $B$ vaccination coverage among high-risk adults: a systematic review. American Journal of Preventive Medicine 2005;28(5 Suppl):248-79. [PUBMED: 15894160]

\section{O'Brien 2007}

O'Brien MA, Rogers S, Jamtvedt G, Oxman AD, OdgaardJensen J, Kristoffersen DT, et al. Educational outreach visits: effects on professional practice and health care outcomes. Cochrane Database of Systematic Reviews 2007, Issue 4. [DOI: 10.1002/14651858.CD000409.pub2; PUBMED: 17943742]

\section{Ogrinc 2016}

Ogrinc G, Davies L, Goodman D, Batalden P, Davidoff F, Stevens D. SQUIRE 2.0 (Standards for QUality Improvement Reporting Excellence): revised publication guidelines from a detailed consensus process. BMJ Quality \& Safety 2016;25(12):986-92. [PUBMED: 26369893]

\section{Oxman 1995}

Oxman AD, Thomson MA, Davis DA, Haynes RB. No magic bullets: a systematic review of 102 trials of interventions to improve professional practice. Canadian Medical Association Journal 1995;153(10):1423-31.

\section{Pantoja 2014}

Pantoja T, Green ME, Grimshaw J, Denig P, Durieux P, Gill P, et al. Manual paper reminders: effects on professional practice and health care outcomes. Cochrane Database of Systematic Reviews 2014, Issue 9. [DOI: 10.1002/14651858.CD001174.pub2; CD001174]

\section{Pearson 2009}

Pearson SA, Moxey A, Robertson J, Hains I, Williamson M, Reeve J, et al. Do computerised clinical decision support systems for prescribing change practice? A systematic review of the literature (1990-2007). BMC Health Services Research 2009;9:154. [PUBMED: 19715591]

\section{Schedlbauer 2009}

Schedlbauer A, Prasad V, Mulvaney C, Phansalkar S, Stanton W, Bates DW, et al. What evidence supports the use of computerized alerts and prompts to improve clinicians' prescribing behavior?. Journal of the American Medical Informatics Association 2009;16(4):531-8. [PUBMED: 19390110]

\section{Shea 1996}

Shea S, DuMouchel W, Bahamonde L. A meta-analysis of 16 randomized controlled trials to evaluate computer-based clinical reminder systems for preventive care in the ambulatory setting. Journal of the American Medical Informatics Association 1996;3(6):399-409. [PUBMED: 8930856]

\section{Shiffman 1999}

Shiffman RN, Liaw Y, Brandt CA, Corb GJ. Computer-based guideline implementation systems: a systematic review of functionality and effectiveness. Journal of the American Medical Informatics Association : JAMIA 1999;6(2):104-14. [PUBMED: 10094063]

\section{Shojania 2009}

Shojania KG, Jennings A, Mayhew A, Ramsay CR, Eccles MP, Grimshaw J. The effects of on-screen, point of care computer reminders on processes and outcomes of care. Cochrane Database of Systematic Reviews 2009, Issue 3. [DOI: 10.1002/14651858.CD001096.pub2]

Computer-generated reminders delivered on paper to healthcare professionals: effects on professional practice and healthcare outcomes 


\section{Siddiqi 2005}

Siddiqi K, Newell J, Robinson M. Getting evidence into practice: what works in developing countries?. International Journal for Quality in Health Care : journal of the International Society for Quality in Health Care ISQua 2005;17(5):447-54. [PUBMED: 15872024]

\section{Stata 2007 [Computer program]}

StataCorp. Stata Statistical Software: Release 10. College Station, TX: StataCorp LP, 2007.

\section{Thomas 1999}

Thomas LH, Cullum NA, McColl E, Rousseau N, Soutter J, Steen N. Guidelines in professions allied to medicine. Cochrane Database of Systematic Reviews 1999, Issue 1. [DOI: 10.1002/14651858.CD000349]

\section{Tierney 2007}

Tierney WM, Rotich JK, Hannan TJ, Siika AM, Biondich PG, Mamlin BW, et al. The AMPATH medical record system: creating, implementing, and sustaining an electronic medical record system to support HIV/AIDS care in western Kenya. Studies in Health Technology and Informatics 2007;129(Pt 1):372-6. [PUBMED: 17911742]

\section{Ukoumunne 1999}

Ukoumunne OC, Gulliford MC, Chinn S, Sterne JA, Burney PG, Donner A. Methods in health service research. Evaluation of health interventions at area and organisation level. BMJ (Clinical Research ed.) 1999;319(7206):376-9. [PUBMED: 10435968]

\section{CHARACTERISTICS OF STUDIES}

Characteristics of included studies [ordered by study ID]

\section{Wensing 1994}

Wensing M, Grol R. Single and combined strategies for implementing changes in primary care: a literature review. International Journal for Quality in Health Care 1994;6(2):115-32.

\section{References to other published versions of this review Arditi 2010}

Arditi C, Rège-Walther $\mathrm{M}$, Burnand $\mathrm{B}$, Wyatt J. Computergenerated paper reminders: effects on professional practice and health care outcomes. Cochrane Database of Systematic Reviews 2010, Issue 5. [DOI: 10.1002/14651858.CD001175.pub2]

\section{Arditi 2012}

Arditi C, Rège-Walther M, Wyatt JC, Durieux $\mathrm{P}$, Burnand B. Computer-generated reminders delivered on paper to healthcare professionals; effects on professional practice and health care outcomes. Cochrane Database of Systematic Reviews 2012, Issue 12. [DOI: 10.1002/14651858.CD001175.pub3]

\section{Gorman 1998}

Gorman P, Redfern C, Liaw T, Carson S, Wyatt JC, Rowe RE, et al. Computer-generated paper reminders: effects on professional practice and health care outcomes. Cochrane Database of Systematic Reviews 1998, Issue 3. [DOI: 10.1002/14651858.CD001175]

* Indicates the major publication for the study

\section{Barnett 1983}

\begin{tabular}{ll}
\hline Methods & Randomized trial, unit of allocation: patient \\
\hline Participants & Patients: blood pressure $\geq 100$, "poor" follow-up, women: 49\%, mean age: $43, \mathrm{n}=115$ \\
& Professionals: physicians, nurses, $\mathrm{n}=$ not clear \\
& Setting: outpatient (Harvard Community Health Plan (HMO), Boston USA) \\
\hline Interventions & Control: usual care \\
& Intervention: physician reminder \\
& Duration of intervention: 20 months
\end{tabular}

Outcomes

Quality of care: rate of repeat blood pressure recorded at 12 months; rate of follow-up attempted or achieved at 12 months (median)

Patient outcomes: percentage patients with blood pressure $<100$ or on treatment

Clinical area and targeted activity 
Barnett 1983 (Continued)

Reminder
Description: If there were not 2 repeat visits that included blood pressure measurement within 6 months after the initial recording of the elevated blood pressure, the COSTAR system was programmed to automatically generate a reminder notice to the patient's primary physician. The physician was notified of the deviation from the standard, and was given an encounter form on which he or she recorded when the next follow-up visit should occur.

Typology: patient-specific: YES, space for response: YES, explicit advice: NO; explanation: NO; reference: NO; at point-of-care: NO

\section{Notes}

\section{Risk of bias}

\begin{tabular}{|c|c|c|}
\hline Bias & Authors' judgement & Support for judgement \\
\hline $\begin{array}{l}\text { Random sequence genera- } \\
\text { tion (selection bias) }\end{array}$ & Unclear risk & "randomly assigned to a control or to an experimental group" \\
\hline $\begin{array}{l}\text { Allocation concealment } \\
\text { (selection bias) }\end{array}$ & Unclear risk & not described \\
\hline $\begin{array}{l}\text { Blinding of outcome as- } \\
\text { sessment (detection bias) } \\
\text { All outcomes }\end{array}$ & Unclear risk & not described \\
\hline $\begin{array}{l}\text { Incomplete outcome data } \\
\text { (attrition bias) } \\
\text { All outcomes }\end{array}$ & Low risk & 8 dropouts in intervention group and 10 in control group \\
\hline $\begin{array}{l}\text { Selective reporting (re- } \\
\text { porting bias) }\end{array}$ & Unclear risk & not clear \\
\hline Other bias & Unclear risk & not clear \\
\hline $\begin{array}{l}\text { Outcomes at baseline sim- } \\
\text { ilar? }\end{array}$ & Unclear risk & not reported \\
\hline $\begin{array}{l}\text { Characteristics at baseline } \\
\text { similar? }\end{array}$ & Low risk & $\begin{array}{l}\text { groups stratified by age and diastolic blood pressure level before randomiza- } \\
\text { tion }\end{array}$ \\
\hline $\begin{array}{l}\text { Adequate protection } \\
\text { against contamination? }\end{array}$ & High risk & physicians treated both intervention and control patients \\
\hline
\end{tabular}

\section{Becker 1989}

\begin{tabular}{|c|c|}
\hline Methods & Randomized trials, unit of allocation: patient \\
\hline \multirow[t]{3}{*}{ Participants } & $\begin{array}{l}\text { Patients: } 40-60 \text { years old; women: } 68 \% \text {, mean age: } 51, n=\sim 700 \text { randomized (395 analyzed in included } \\
\text { study groups) }\end{array}$ \\
\hline & Professionals: physicians, $\mathrm{n}=$ not clear \\
\hline & Setting: outpatient (University of Virginia internal medicine clinic, Charlottesville, USA) \\
\hline \multirow[t]{2}{*}{ Interventions } & Control: usual care \\
\hline & Intervention: physician reminder \\
\hline
\end{tabular}

Computer-generated reminders delivered on paper to healthcare professionals: effects on professional practice and healthcare outcomes 
Becker 1989 (Continued)

Duration of intervention: nine months

Outcomes Quality of care: overall compliance rate with preventive care guidelines (primary); compliance with: dental exam, ocular pressure check, fecal occult blood test, influenza vaccination, pneumococcal vaccination, tetanus toxoid, mammography, pap smear

Clinical area and targeted Preventive care (multiple: test ordering, vaccination) activity

Description: A standardized telephone questionnaire and computer program were used to create an individualized schedule for preventive care needs. The reminder specified for the patient which services were necessary and when they should be obtained. Physician received the reminder as a memorandum appended to each patient's chart at the first visit after the telephone interview. If there was no scheduled visit, the reminder was mailed to the patient's primary physician.

Typology: patient-specific: YES; space for response: NO; explicit advice: YES; explanation: NOT CLEAR ; reference: NO; at point-of-care: YES

Notes Additional study intervention excluded from analyses: patient reminder

\section{Risk of bias}

\begin{tabular}{|c|c|c|}
\hline Bias & Authors' judgement & Support for judgement \\
\hline $\begin{array}{l}\text { Random sequence genera- } \\
\text { tion (selection bias) }\end{array}$ & Unclear risk & "eligible patients were randomly assigned to three study groups" \\
\hline $\begin{array}{l}\text { Allocation concealment } \\
\text { (selection bias) }\end{array}$ & Unclear risk & not described \\
\hline $\begin{array}{l}\text { Blinding of outcome as- } \\
\text { sessment (detection bias) } \\
\text { All outcomes }\end{array}$ & Unclear risk & $\begin{array}{l}\text { data gathered through outpatient medical record review, but no mention of } \\
\text { blinding }\end{array}$ \\
\hline $\begin{array}{l}\text { Incomplete outcome data } \\
\text { (attrition bias) } \\
\text { All outcomes }\end{array}$ & Low risk & $\begin{array}{l}\text { authors gave reasons for data excluded from analysis and compared a random } \\
\text { sample of excluded patients with included patients }\end{array}$ \\
\hline $\begin{array}{l}\text { Selective reporting (re- } \\
\text { porting bias) }\end{array}$ & Unclear risk & not clear \\
\hline Other bias & Unclear risk & not clear \\
\hline $\begin{array}{l}\text { Outcomes at baseline sim- } \\
\text { ilar? }\end{array}$ & Unclear risk & not reported \\
\hline $\begin{array}{l}\text { Characteristics at baseline } \\
\text { similar? }\end{array}$ & Low risk & "The experimental groups were similar in all characteristics." \\
\hline $\begin{array}{l}\text { Adequate protection } \\
\text { against contamination? }\end{array}$ & High risk & patients randomized \\
\hline
\end{tabular}

Binstock 1997

Methods Randomized trial, unit of allocation: patient


Binstock 1997 (Continued)

Participants
Patients: women 25-49 years old without pap smear in previous three years, $n=3052$

Professionals: physicians, $\mathrm{n}=$ not clear

Setting: outpatient ( 3 medical centers of a Kaiser Permanente HMO, USA)

Interventions

Control: usual care

Intervention: physician reminder

Duration of intervention: not clear

Quality of care: pap smear rate within 12 months if due (primary)
Resource use/financial: total estimated costs; estimated costs per pap smear obtained

Clinical area and targeted Preventive care/cervical cancer (test ordering) activity

\begin{tabular}{|c|c|c|}
\hline Reminder & \multicolumn{2}{|c|}{$\begin{array}{l}\text { Description: A chart reminder was affixed to the outside of the patient's medical record. Computerized } \\
\text { laboratory files were used to identify women without a pap smear in the previous } 3 \text { years. } \\
\text { Typology: patient-specific: YES; space for response: NOT CLEAR; explicit advice: NOT CLEAR; explana- } \\
\text { tion: NOT CLEAR; reference: NOT CLEAR; at point-of-care: YES }\end{array}$} \\
\hline \multicolumn{3}{|l|}{ Notes } \\
\hline \multicolumn{3}{|l|}{ Risk of bias } \\
\hline Bias & Authors' judgement & Support for judgement \\
\hline $\begin{array}{l}\text { Random sequence genera- } \\
\text { tion (selection bias) }\end{array}$ & Unclear risk & "randomly assigned" \\
\hline $\begin{array}{l}\text { Allocation concealment } \\
\text { (selection bias) }\end{array}$ & Unclear risk & not described \\
\hline $\begin{array}{l}\text { Blinding of outcome as- } \\
\text { sessment (detection bias) } \\
\text { All outcomes }\end{array}$ & Low risk & outcome data from computerized laboratory records \\
\hline $\begin{array}{l}\text { Incomplete outcome data } \\
\text { (attrition bias) } \\
\text { All outcomes }\end{array}$ & Unclear risk & not clear \\
\hline $\begin{array}{l}\text { Selective reporting (re- } \\
\text { porting bias) }\end{array}$ & Unclear risk & not clear \\
\hline Other bias & Unclear risk & not clear \\
\hline $\begin{array}{l}\text { Outcomes at baseline sim- } \\
\text { ilar? }\end{array}$ & Unclear risk & not reported \\
\hline $\begin{array}{l}\text { Characteristics at baseline } \\
\text { similar? }\end{array}$ & Unclear risk & not reported \\
\hline $\begin{array}{l}\text { Adequate protection } \\
\text { against contamination? }\end{array}$ & High risk & patients randomized \\
\hline
\end{tabular}

Computer-generated reminders delivered on paper to healthcare professionals: effects on professional practice and healthcare outcomes 
Burack 1996

\begin{tabular}{|c|c|}
\hline Methods & Randomized trial, unit of allocation: patient \\
\hline \multirow[t]{3}{*}{ Participants } & $\begin{array}{l}\text { Patients: women, } \geq 40 \text { years old, mean age: not clear, } n=2368 \text { women randomized ( } 1527 \text { analyzed in in- } \\
\text { cluded study groups) }\end{array}$ \\
\hline & $\begin{array}{l}\text { Professionals: } 20 \text { physicians ( } 2 \text { family medicine physicians, } 9 \text { internal medicine physicians, } 9 \text { gynecolo- } \\
\text { gists) }\end{array}$ \\
\hline & Setting: outpatient (2 sites of a large HMO, Detroit, USA) \\
\hline \multirow[t]{5}{*}{ Interventions } & Control (comparison 1): usual care \\
\hline & Intervention (comparison 1): physician reminder \\
\hline & Active control (comparison 2): patient reminder \\
\hline & Intervention (comparison 2): physician reminder; patient reminder \\
\hline & Duration of intervention: 12 months \\
\hline
\end{tabular}

\begin{tabular}{ll}
\hline Outcomes & Quality of care: mammography rate if due (primary) \\
\hline $\begin{array}{l}\text { Clinical area and targeted } \\
\text { activity }\end{array}$ & Preventive care/breast cancer (test ordering) \\
\hline
\end{tabular}

Description: Electronic HMO administrative records and previous mammograms were employed to as-
sess eligibility. The reminder forms were generated off-site and placed in medical records by the re-
search team. The physician reminder was a brightly colored single page notice placed in the medical
chart 1 month before the due date. In addition, the reminder displayed information concerning pre-
vious mammograms and allowed the physician to recommend an alternative due date. The reminder
was removed from the chart once documentation of completed mammography was obtained.
Typology: patient-specific: YES; space for response: YES; explicit advice: YES; explanation: NO; refer-
ence: NO; at point-of-care: YES

Notes Data extracted from graphics. Author not contacted because publication date $>10$ years.

\section{Risk of bias}

\begin{tabular}{|c|c|c|}
\hline Bias & Authors' judgement & Support for judgement \\
\hline $\begin{array}{l}\text { Random sequence genera- } \\
\text { tion (selection bias) }\end{array}$ & Unclear risk & "randomly assigned" \\
\hline $\begin{array}{l}\text { Allocation concealment } \\
\text { (selection bias) }\end{array}$ & Unclear risk & not described \\
\hline $\begin{array}{l}\text { Blinding of outcome as- } \\
\text { sessment (detection bias) } \\
\text { All outcomes }\end{array}$ & Low risk & electronic administrative records were used \\
\hline $\begin{array}{l}\text { Incomplete outcome data } \\
\text { (attrition bias) } \\
\text { All outcomes }\end{array}$ & Low risk & 2368 women randomized -741 with no visits $=1627$ analyzed $(68.7 \%)$ \\
\hline $\begin{array}{l}\text { Selective reporting (re- } \\
\text { porting bias) }\end{array}$ & Unclear risk & not clear \\
\hline
\end{tabular}

Computer-generated reminders delivered on paper to healthcare professionals: effects on professional practice and healthcare outcomes 36 (Review)

Copyright (c) 2017 The Cochrane Collaboration. Published by John Wiley \& Sons, Ltd. 
Burack 1996 (Continued)

\begin{tabular}{lll} 
Other bias & Unclear risk & not clear \\
\hline $\begin{array}{l}\text { Outcomes at baseline sim- } \\
\text { ilar? }\end{array}$ & Unclear risk & not reported \\
\hline $\begin{array}{l}\text { Characteristics at baseline } \\
\text { similar? }\end{array}$ & Low risk & $\begin{array}{l}\text { "There were no significant differences among characteristics of the interven- } \\
\text { tion groups" }\end{array}$ \\
\hline $\begin{array}{l}\text { Adequate protection } \\
\text { against contamination? }\end{array}$ & High risk & patients randomized \\
\hline
\end{tabular}

\section{Burack 1998}

\begin{tabular}{ll}
\hline Methods & Randomized trial, unit of allocation: patient \\
\hline Participants & $\begin{array}{l}\text { Patients: women, } 18-40 \text { years old, mean age: not clear, } \mathrm{n}=5801 \text { women randomized (3848 analyzed in } \\
\text { included study groups) }\end{array}$ \\
& $\begin{array}{l}\text { Professionals: } 20 \text { physicians ( } 2 \text { family medicine physicians, } 9 \text { internal medicine physicians, } 9 \text { gynecolo- } \\
\text { gists) } \\
\text { Setting: outpatient (three sites of a large HMO, Detroit, USA) }\end{array}$
\end{tabular}

Intervention (comparison 1): physician reminder

Active control (comparison 2): patient reminder

Intervention (comparison 2): physician reminder; patient reminder

Duration of intervention: 14 months

\begin{tabular}{ll}
\hline Outcomes & Quality of care: pap smear rate if due (primary) \\
\hline $\begin{array}{l}\text { Clinical area and targeted } \\
\text { activity }\end{array}$ & Preventive care/cervical cancer (test ordering) \\
\hline Reminder & $\begin{array}{l}\text { Description: The reminder forms were computer-generated off-site and placed in medical records by } \\
\text { the research team. The physician reminder was a brightly colored single page notice that included pa- } \\
\text { tient specific pap smear information. The notice was prominently placed at the front of the patient's } \\
\text { medical chart } 2 \text { months before the due date. The reminder was removed from chart once documenta- } \\
\text { tion of completed pap smear was obtained. } \\
\text { Typology: patient-specific: YES; space for response: NO; explicit advice: YES; explanation: NO; refer- } \\
\text { ence: NO; at point-of-care: YES }\end{array}$ \\
\hline 2 of the 3 sites had previously participated in a related trial on reminders.
\end{tabular}

\section{Risk of bias}

\section{Bias \\ Authors' judgement Support for judgement}

Random sequence genera- Unclear risk tion (selection bias) "women were first randomly assigned, using a site specific, stratified randomization procedure to physician reminder intervention; women were then randomized to the patient reminder intervention on a weekly basis in groups of $156^{\prime \prime}$ 
Burack 1998 (Continued)

\begin{tabular}{|c|c|c|}
\hline $\begin{array}{l}\text { Allocation concealment } \\
\text { (selection bias) }\end{array}$ & Unclear risk & not described \\
\hline $\begin{array}{l}\text { Blinding of outcome as- } \\
\text { sessment (detection bias) } \\
\text { All outcomes }\end{array}$ & Unclear risk & paper copies of pap smear results received: no indication of blinding. \\
\hline $\begin{array}{l}\text { Incomplete outcome data } \\
\text { (attrition bias) } \\
\text { All outcomes }\end{array}$ & High risk & 5801 women randomized but 3848 analyzed (66.3\%) \\
\hline $\begin{array}{l}\text { Selective reporting (re- } \\
\text { porting bias) }\end{array}$ & Unclear risk & not clear \\
\hline Other bias & Unclear risk & not clear \\
\hline $\begin{array}{l}\text { Outcomes at baseline sim- } \\
\text { ilar? }\end{array}$ & Unclear risk & not reported \\
\hline $\begin{array}{l}\text { Characteristics at baseline } \\
\text { similar? }\end{array}$ & Low risk & $\begin{array}{l}\text { characteristics of women were similar and there were no significant differ- } \\
\text { ences }\end{array}$ \\
\hline $\begin{array}{l}\text { Adequate protection } \\
\text { against contamination? }\end{array}$ & High risk & patients randomized \\
\hline
\end{tabular}

\section{Chambers 1989}

\begin{tabular}{|c|c|}
\hline Methods & Randomized trial, unit of allocation: patient \\
\hline \multirow[t]{3}{*}{ Participants } & Patients: women, $\geq 40$ years old, mean age: $62, n=1262$ \\
\hline & $\begin{array}{l}\text { Professionals: } 30 \text { physicians ( } 12 \text { faculty and } 18 \text { residents) ( } 2 \text { providers involved in study excluded from } \\
\text { analyses) }\end{array}$ \\
\hline & $\begin{array}{l}\text { Setting: outpatient (Family practice center of the department of Family Medicine, University hospital, } \\
\text { Philadelphia, USA) }\end{array}$ \\
\hline \multirow[t]{3}{*}{ Interventions } & Control: usual care \\
\hline & Intervention: physician reminder \\
\hline & Duration of intervention: 6 months \\
\hline Outcomes & Quality of care: mammography rate if due (primary); mammography rate \\
\hline $\begin{array}{l}\text { Clinical area and targeted } \\
\text { activity }\end{array}$ & Preventive care/breast cancer (test ordering) \\
\hline \multirow[t]{2}{*}{ Reminder } & $\begin{array}{l}\text { Description: The date of the last mammogram ordered and entered into the database was displayed in } \\
\text { the comments section of the encounter form for each visit. The information was printed as "last mam- } \\
\text { mogram: date" or, if no mammogram was on record in the database (none since 1984), the notation } \\
\text { listed "last mammogram?" The physician ordered the mammogram by writing for one in the test or- } \\
\text { dered section of the encounter form. }\end{array}$ \\
\hline & $\begin{array}{l}\text { Typology: patient-specific: YES; space for response: YES; explicit advice: NO; explanation: NO; refer- } \\
\text { ence: NO; at point-of-care: YES }\end{array}$ \\
\hline
\end{tabular}

Computer-generated reminders delivered on paper to healthcare professionals: effects on professional practice and healthcare outcomes 
Chambers 1989 (Continued)

Notes

\section{Risk of bias}

\begin{tabular}{|c|c|c|}
\hline Bias & Authors' judgement & Support for judgement \\
\hline $\begin{array}{l}\text { Random sequence genera- } \\
\text { tion (selection bias) }\end{array}$ & Low risk & "assigned according to a computer-generated random number program" \\
\hline $\begin{array}{l}\text { Allocation concealment } \\
\text { (selection bias) }\end{array}$ & Unclear risk & not described \\
\hline $\begin{array}{l}\text { Blinding of outcome as- } \\
\text { sessment (detection bias) } \\
\text { All outcomes }\end{array}$ & Unclear risk & "data entered by office receptionists" \\
\hline $\begin{array}{l}\text { Incomplete outcome data } \\
\text { (attrition bias) } \\
\text { All outcomes }\end{array}$ & Unclear risk & $\begin{array}{l}\text { patients ( } n=\text { not clear) from the } 2 \text { physician investigators excluded from analy- } \\
\text { sis }\end{array}$ \\
\hline $\begin{array}{l}\text { Selective reporting (re- } \\
\text { porting bias) }\end{array}$ & Unclear risk & not clear \\
\hline Other bias & Unclear risk & not clear \\
\hline $\begin{array}{l}\text { Outcomes at baseline sim- } \\
\text { ilar? }\end{array}$ & Low risk & some proportion of women up-to-date at baseline \\
\hline $\begin{array}{l}\text { Characteristics at baseline } \\
\text { similar? }\end{array}$ & Low risk & $\begin{array}{l}\text { "the subjects in the experimental and control groups were similar in age, race, } \\
\text { insurance coverage and complexity of disease". }\end{array}$ \\
\hline $\begin{array}{l}\text { Adequate protection } \\
\text { against contamination? }\end{array}$ & High risk & physicians likely saw patients with and without reminders \\
\hline
\end{tabular}

Chambers 1991

\begin{tabular}{|c|c|}
\hline Methods & Cluster randomized trial, unit of allocation: health professional (stratified by level of training) \\
\hline \multirow[t]{3}{*}{ Participants } & $\begin{array}{l}\text { Patients: } \geq 65 \text { years old or with any of the following clinical diagnoses: diabetes, renal failure, anemia, } \\
\text { congestive heart failure, asthma, or chronic obstructive pulmonary disease; women: } 74 \% \text {; mean age: } \\
\text { not clear, } n=489 \text { analyzed }\end{array}$ \\
\hline & Professionals: 30 physicians (12 faculty and 18 residents) \\
\hline & Setting: outpatient (Family practice center, Thomas Jefferson University, Philadelphia, USA) \\
\hline \multirow[t]{3}{*}{ Interventions } & Control: usual care \\
\hline & Intervention: physician reminders (always) \\
\hline & Duration of intervention: 2 months \\
\hline Outcomes & Quality of care: vaccination rate if due (primary) \\
\hline $\begin{array}{l}\text { Clinical area and targeted } \\
\text { activity }\end{array}$ & Preventive care/influenza (vaccination) \\
\hline
\end{tabular}

Computer-generated reminders delivered on paper to healthcare professionals: effects on professional practice and healthcare outcomes 
Chambers 1991 (Continued)

Reminder
Description: "Flu vac in 1987?__" appears on the encounter form, computer-generated for each visit when a patient arrives at the receptionist's desk, which is then attached to the front of the patient chart; it includes space for information regarding tests and procedures ordered.

Typology: patient-specific: NO; space for response: YES; explicit advice: NO; explanation: NO; reference: NO; at point-of-care: YES

Additional study intervention excluded from analyses: physicians reminders (sometimes: printed for half the eligible patients)

\section{Risk of bias}

\begin{tabular}{|c|c|c|}
\hline Bias & Authors' judgement & Support for judgement \\
\hline $\begin{array}{l}\text { Random sequence genera- } \\
\text { tion (selection bias) }\end{array}$ & Low risk & "Physician randomly assigned via a computerized randomization program" \\
\hline $\begin{array}{l}\text { Allocation concealment } \\
\text { (selection bias) }\end{array}$ & Unclear risk & not described \\
\hline $\begin{array}{l}\text { Blinding of outcome as- } \\
\text { sessment (detection bias) } \\
\text { All outcomes }\end{array}$ & Unclear risk & not clear \\
\hline $\begin{array}{l}\text { Incomplete outcome data } \\
\text { (attrition bias) } \\
\text { All outcomes }\end{array}$ & Low risk & $\begin{array}{l}864 \text { patients randomized - } 51 \text { received vaccination before start - } 93 \text { saw multi- } \\
\text { ple physicians }-24 \text { drop-in visits }=686 \text { analyzed }(79.4 \%)\end{array}$ \\
\hline $\begin{array}{l}\text { Selective reporting (re- } \\
\text { porting bias) }\end{array}$ & Unclear risk & not clear \\
\hline Other bias & Unclear risk & not clear \\
\hline $\begin{array}{l}\text { Outcomes at baseline sim- } \\
\text { ilar? }\end{array}$ & Unclear risk & not reported \\
\hline $\begin{array}{l}\text { Characteristics at baseline } \\
\text { similar? }\end{array}$ & Unclear risk & not reported \\
\hline $\begin{array}{l}\text { Adequate protection } \\
\text { against contamination? }\end{array}$ & Low risk & $\begin{array}{l}\text { physician assignment overruled patient assignment: physicians in control } \\
\text { group never received a reminder }\end{array}$ \\
\hline
\end{tabular}

Dexter 1998

\begin{tabular}{ll} 
Methods & Cluster randomized trial ( $2 \times 2$ factorial design), unit of allocation: half-day session, $n=30$ \\
\hline Participants & $\begin{array}{l}\text { Patients: } \geq 75 \text { years old or } \geq 50 \text { with serious underlying disease, women: } 66 \%, \text { mean age: } 65, \mathrm{n}=1394 \text { el- } \\
\text { igible patients ( } 1009 \text { analyzed), } \mathrm{n}=1160 \text { patient/physician pairs }\end{array}$ \\
& Professionals: 147 providers ( 39 faculty, 108 residents) \\
& Setting: outpatient (4 practices with 8 half-day sessions each, Indiana University, USA)
\end{tabular}

Interventions

Control: usual care

Intervention (3 intervention arms combined): physician reminder 
Dexter 1998 (Continued)

Duration of intervention: not clear

Outcomes Quality of care: rate of patients who completed either directives; patient/physician pair who discussed directives

Clinical area and targeted Advance directives for patients at risk for acute deterioration (professional-patient communication) activity

Reminder Description: All physicians routinely received computer-generated reminders for patients with scheduled visits. They were reminded to give preventive care, note abnormal results, and avoid drug interactions. These reminders appeared at the bottom of computer-generated printed encounter forms. The advance directive reminders were followed by a choice list (discussed today, next visit, not applicable, patient too ill, patient refuses to discuss, I disagree with advance directives).

Typology: patient-specific: YES; space for response: YES; explicit advice: YES; explanation: NO; reference: NO; at point-of-care: YES

$\begin{array}{ll}\text { Notes } & \text { Intervention a: physician reminder for instruction directive } \\ \text { Intervention b: physician reminder for proxy directive } \\ \text { Intervention c: physician reminder for both }\end{array}$

\section{Risk of bias}

\begin{tabular}{|c|c|c|}
\hline Bias & Authors' judgement & Support for judgement \\
\hline $\begin{array}{l}\text { Random sequence genera- } \\
\text { tion (selection bias) }\end{array}$ & Unclear risk & $\begin{array}{l}\text { "we randomly assigned all of the physicians who worked in a particular half- } \\
\text { day session to the same reminder category." }\end{array}$ \\
\hline $\begin{array}{l}\text { Allocation concealment } \\
\text { (selection bias) }\end{array}$ & Unclear risk & not described \\
\hline $\begin{array}{l}\text { Blinding of outcome as- } \\
\text { sessment (detection bias) } \\
\text { All outcomes }\end{array}$ & Low risk & $\begin{array}{l}\text { research assistants who collected data were blinded at all times to the pa- } \\
\text { tient's study groups }\end{array}$ \\
\hline $\begin{array}{l}\text { Incomplete outcome data } \\
\text { (attrition bias) } \\
\text { All outcomes }\end{array}$ & Low risk & $\begin{array}{l}1394 \text { eligible patients - } 42 \text { missed by research assistant - } 83 \text { low scores - } 36 \text { in } \\
\text { nursing homes or prison }-29 \text { deaf or spoke no English }-9 \text { completed advanced } \\
\text { directive }-5 \text { for other reasons }=1190 \text { patients interviewed and } 1042 \text { enrolled - } \\
33 \text { patients cared for by } 10 \text { physicians who changed sessions }=1009 \text { analyzed }\end{array}$ \\
\hline $\begin{array}{l}\text { Selective reporting (re- } \\
\text { porting bias) }\end{array}$ & Unclear risk & not clear \\
\hline Other bias & Unclear risk & not clear \\
\hline $\begin{array}{l}\text { Outcomes at baseline sim- } \\
\text { ilar? }\end{array}$ & Unclear risk & not reported \\
\hline $\begin{array}{l}\text { Characteristics at baseline } \\
\text { similar? }\end{array}$ & High risk & $\begin{array}{l}\text { similar, except for ethnicity and coronary heart disease and significant differ- } \\
\text { ence among groups for "had ever thought about advance directive": higher for } \\
\text { control group }\end{array}$ \\
\hline $\begin{array}{l}\text { Adequate protection } \\
\text { against contamination? }\end{array}$ & Low risk & $\begin{array}{l}\text { " } 16 \text { physicians practiced in more than one session per week: therefore we ran- } \\
\text { domly assigned the sessions in a stepped manner by first allocating the } 16 \\
\text { physicians and all of their associated sessions; we then randomly assigned the } \\
\text { remaining eight sessions" }\end{array}$ \\
\hline
\end{tabular}


Gilutz 2009

\begin{tabular}{ll}
\hline Methods & Cluster-randomized trial, unit of allocation: primary clinics $(\mathrm{n}=112)$ \\
\hline Participants & Patients: women: $37.5 \%$, mean age: $65.6, \mathrm{n}=7448$ \\
& Professionals: physicians, nurses, $\mathrm{n}=600$ \\
& Setting: outpatient (112 primary care clinics of a HMO, Israel)
\end{tabular}

Interventions Control: usual care

Intervention: physician reminder

Duration of intervention: 6-36 months (mean: 21)

Outcomes Quality of care: rate of appropriate lipoprotein monitoring; rate of initiation or up-titration of statin therapy; rate of up-titration in eligible patients

Patient outcomes: LDL levels, event-free survival (only intervention group data)

Clinical area and targeted Cardiovascular disease (multiple: general management, prescription) activity

A written reminder with patient-tailored recommendations was mailed to the primary care physicians
and nurses. The recommendations were based on the previous 6 months data for new patients, and 4
months for patients in periodic follow-up. The reminder indicated the patient's risk factors, lipoprotein
values, and known dispensed medications. Lipid-lowering drug treatment was recommended only in
patients with $L D L>110 \mathrm{mg} / \mathrm{dL}$ and consisted of either statin initiation (simvastatin $20 \mathrm{mg} / \mathrm{day})$, statin
up-titration (doubling the last registered dose), changing to a more potent statin or compliance evalua-
tion. For unresponsive and compliant patients it was recommended that they be referred to a metabol-
ic clinic.

Typology: patient-specific: YES; space for response: NOT CLEAR; explicit advice: YES; explanation: YES; reference: NOT CLEAR; at point-of-care: NO

\section{Notes}

\section{Risk of bias}

\begin{tabular}{|c|c|c|}
\hline Bias & Authors' judgement & Support for judgement \\
\hline $\begin{array}{l}\text { Random sequence genera- } \\
\text { tion (selection bias) }\end{array}$ & Unclear risk & Method of randomization not described in paper. \\
\hline $\begin{array}{l}\text { Allocation concealment } \\
\text { (selection bias) }\end{array}$ & Unclear risk & insufficient information \\
\hline $\begin{array}{l}\text { Blinding of outcome as- } \\
\text { sessment (detection bias) } \\
\text { All outcomes }\end{array}$ & Low risk & $\begin{array}{l}\text { administrative data. "data were collected from three routinely used databas- } \\
\text { es" }\end{array}$ \\
\hline $\begin{array}{l}\text { Incomplete outcome data } \\
\text { (attrition bias) } \\
\text { All outcomes }\end{array}$ & Low risk & $\begin{array}{l}\text { The number of attrition and exclusions pre-randomization were reported, as } \\
\text { well as reasons for attrition/exclusions. No exclusions after randomization. }\end{array}$ \\
\hline $\begin{array}{l}\text { Selective reporting (re- } \\
\text { porting bias) }\end{array}$ & High risk & $\begin{array}{l}\text { Outcomes defined in the methods are not reported in the results (initiation of } \\
\text { statin, LDL levels in middle and low groups, and secondary outcomes (mortali- } \\
\text { ty and hospitalizations)) }\end{array}$ \\
\hline
\end{tabular}


Gilutz 2009 (Continued)

\begin{tabular}{lll} 
Other bias & Unclear risk & not clear. \\
\hline $\begin{array}{l}\text { Outcomes at baseline sim- } \\
\text { ilar? }\end{array}$ & Unclear risk & No baseline measures of outcomes \\
\hline $\begin{array}{l}\text { Characteristics at baseline } \\
\text { similar? }\end{array}$ & High risk & $\begin{array}{l}\text { "Patients in the intervention and control groups were similar in most parame- } \\
\text { ters. However, there were significantly more patients with a history of myocar- } \\
\text { dial infarction }(33.0 \% \text { vs. } 29.9 \%, P=0.004) \text { and percutaneous coronary inter- } \\
\text { vention }(26.2 \% \text { vs. } 23.8 \%, P=0.019) \text { in the intervention arm." }\end{array}$
\end{tabular}

Adequate protection Low risk Clinic randomized to avoid contamination.

against contamination?

Heidenreich 2005

\begin{tabular}{ll}
\hline Methods & Randomized trial, unit of allocation: patient \\
\hline Participants & Patients: ventricular ejection fraction <40\%; women: $0.7 \%$; mean age: $67.5, \mathrm{n}=600$ [277 analyzed] \\
& Professionals: not clear \\
& Setting: inpatient and outpatient (VA, Palo Alto, USA)
\end{tabular}

\begin{tabular}{|c|c|}
\hline \multirow[t]{3}{*}{ Interventions } & Control: usual care \\
\hline & Intervention: physician reminder \\
\hline & Duration of intervention: 18 months \\
\hline \multirow[t]{2}{*}{ Outcomes } & Quality of care: ACE inhibitor use rate (primary) \\
\hline & Patient outcomes: mean systolic/diastolic blood pressure; mean creatinine level; mortality \\
\hline $\begin{array}{l}\text { Clinical area and targeted } \\
\text { activity }\end{array}$ & Ventricular dysfunction (prescribing) \\
\hline \multirow[t]{2}{*}{ Reminder } & $\begin{array}{l}\text { Description: Echocardiography reports included this statement: "Note: patients with ejection fraction } \\
40 \% \text { have a survival benefit with ACE inhibitors (goal dose lisinopril or fosinopril } 30-40 \mathrm{mg} / \text { day)". }\end{array}$ \\
\hline & $\begin{array}{l}\text { Typology: patient-specific: YES; space for response: NO; explicit advice: YES; explanation: YES; refer- } \\
\text { ence: NO; at point-of-care: YES }\end{array}$ \\
\hline
\end{tabular}

Notes

\section{Risk of bias}

\begin{tabular}{lll}
\hline Bias & Authors' judgement & Support for judgement \\
\hline $\begin{array}{l}\text { Random sequence genera- } \\
\text { tion (selection bias) }\end{array}$ & Low risk & $\begin{array}{l}\text { "Patient selection and randomization were computerized and performed in } \\
\text { conjunction with the generation of the reminder: patients who met study entry } \\
\text { criteria were randomized using a computerized random number generator." }\end{array}$ \\
\hline $\begin{array}{l}\text { Allocation concealment } \\
\text { (selection bias) }\end{array}$ & Low risk & $\begin{array}{l}\text { "Allocation was concealed from all echocardiographers until the reminder ap- } \\
\text { peared on the report." }\end{array}$ \\
\hline $\begin{array}{l}\text { Blinding of outcome as- } \\
\text { sessment (detection bias) }\end{array}$ & Unclear risk & $\begin{array}{l}\text { "medication use was determined from review of inpatient or outpatient en- } \\
\text { counters" }\end{array}$
\end{tabular}

Computer-generated reminders delivered on paper to healthcare professionals: effects on professional practice and healthcare outcomes 
Heidenreich 2005 (Continued)

All outcomes

Incomplete outcome data Low risk (attrition bias)

All outcomes
Among the 600 eligible and randomized patients, 201 were excluded from analyses as they were already on ACE-inhibitor or appropriate alternative at the time of randomization (96 [32.9\%] in intervention group and 105 [34.1\%] in control group), 46 died within 2 months of the echocardiogram (20 [6.8\%] in intervention group and 26 [8.4\%] in control group), 71 left the VA healthcare system (36 [12.3\%] in intervention group and 35 [11.4\%] in control group), and 5 had an allergy or adverse reaction to ACE-inhibitors (3 [1\%] in intervention group and 2 [0.6\%] in control group). In total, 323 [53.8\%] were excluded from analyses (155 [53.1\%] in intervention group and 168 [54.5\%] in control group).

\begin{tabular}{lll}
\hline $\begin{array}{l}\text { Selective reporting (re- } \\
\text { porting bias) }\end{array}$ & Unclear risk & not clear \\
\hline Other bias & Unclear risk & not clear \\
\hline $\begin{array}{l}\text { Outcomes at baseline sim- } \\
\text { ilar? }\end{array}$ & Low risk & no significant difference between groups for ACE inhibitor use \\
\hline $\begin{array}{l}\text { Characteristics at baseline } \\
\text { similar? }\end{array}$ & Low risk & $\begin{array}{l}\text { no significant difference except for history of heart failure, but not extreme. } \\
\text { Adjusted for in multivariate analyses. }\end{array}$ \\
\hline $\begin{array}{l}\text { Adequate protection } \\
\text { against contamination? }\end{array}$ & High risk & patients randomized rather than physicians \\
\hline
\end{tabular}

Heidenreich 2007

\begin{tabular}{ll}
\hline Methods & Randomized trial, unit of allocation: patient \\
\hline Participants & Patients: men: $98 \%$, mean age: $69, \mathrm{n}=1546$ [1271 analyzed] \\
& Professionals: physicians ( $\mathrm{n}=45)$ and nurse practitioners $(\mathrm{n}=5), \mathrm{n}=50$ \\
& Setting: outpatient and inpatient (VA, Palo Alto, USA) \\
\hline Interventions & Control: usual care \\
& Intervention: physician reminder \\
& Duration of intervention: 56 months \\
\hline
\end{tabular}

Outcomes Quality of care: prescription rate of any beta-blocker within 9 months (primary); prescription rate of recommended beta-blockers within 9 months

Clinical area and targeted Ventricular dysfunction (prescribing) activity

Reminder

\begin{abstract}
Description: In the process of printing the completed echocardiography report, the computer algorithm checked the electronic report and had a reminder attached to the report of eligible patients meeting the pre-defined criteria. The reminder included the following statement: "Note: Patients with reduced left ventricular ejection fraction have a survival benefit with beta-blockers (initial dose: carvedilol $3.125 \mathrm{mg}$ BID or metoprolol succinate $12.5 \mathrm{mg}$ BID)". The reminder also recommended cardiology follow-up if the patient had New York Heart Association class II or IV symptoms.
\end{abstract}

Typology: patient-specific: YES; space for response: NO; explicit advice: YES; explanation: YES; reference: NO; at point-of-care: YES 
Heidenreich 2007 (Continued)

Notes

\section{Risk of bias}

Bias Authors' judgement Support for judgement

\begin{tabular}{ll}
\hline $\begin{array}{l}\text { Random sequence genera- } \\
\text { tion (selection bias) }\end{array}$ & Low risk \\
& $\begin{array}{l}\text { minder with an electronic database: patients meeting study criteria were ran- } \\
\text { domized with a computerized random number generator. }\end{array}$ \\
& performed separately at each site"
\end{tabular}

\begin{tabular}{ll}
\hline $\begin{array}{l}\text { Allocation concealment } \\
\text { (selection bias) }\end{array}$ & Low risk \\
& peared on the report."
\end{tabular}

\begin{tabular}{|c|c|c|}
\hline $\begin{array}{l}\text { Blinding of outcome as- } \\
\text { sessment (detection bias) } \\
\text { All outcomes }\end{array}$ & Low risk & "prescription was determined with the VA pharmacy database" \\
\hline
\end{tabular}

\begin{tabular}{|c|c|c|}
\hline $\begin{array}{l}\text { Incomplete outcome data } \\
\text { (attrition bias) } \\
\text { All outcomes }\end{array}$ & Low risk & $\begin{array}{l}\text { See Figure 1: Among the } 1546 \text { eligible and randomized patients, } 89 \text { died within } \\
30 \text { days of the echocardiogram ( } 44 \text { [5.8\%] in intervention group and } 45 \text { [5.7\%] } \\
\text { in control group), } 180 \text { left the healthcare system ( } 88 \text { [11.7\%] in intervention } \\
\text { group and } 92[11.6 \%] \text { in control group), and } 6 \text { had an echocardiography at }>1 \\
\text { site }(2[0.3 \%] \text { in intervention group and } 4[0.5 \%] \text { in control group). In total, } 275 \\
\text { [17.8\%] were excluded from analyses ( } 134[17.7 \%] \text { in intervention group and } \\
141[17.8 \%] \text { in control group). Exclusions did not significantly differ between } \\
\text { groups. }\end{array}$ \\
\hline
\end{tabular}

\begin{tabular}{lll}
\hline $\begin{array}{l}\text { Selective reporting (re- } \\
\text { porting bias) }\end{array}$ & Unclear risk & not clear \\
\hline Other bias & Unclear risk & not clear \\
\hline
\end{tabular}

\begin{tabular}{l}
$\begin{array}{l}\text { Outcomes at baseline sim- } \\
\text { ilar? }\end{array}$ \\
\hline
\end{tabular}

Characteristics at baseline Low risk no significant difference except for percentage of male, but not extreme.
similar?
similar?

Adequate protection
against contamination? High risk patients randomized rather than physicians.

\section{Heiman 2004}

\begin{tabular}{|c|c|}
\hline Methods & Cluster-randomized trial, unit of allocation: clinic, $n=5$ \\
\hline \multirow[t]{3}{*}{ Participants } & $\begin{array}{l}\text { Patients: } \geq 70 \text { yr or } \geq 50 \text { yr with severe chronic illness, without advanced directives; women: } 68 \% \text {; mean } \\
\text { age: } 72 ; n=719 \text { in included study arms }\end{array}$ \\
\hline & Professionals: 31 providers in included study arms \\
\hline & Setting: outpatient ( 5 clinics in 5 general practices in Boston, USA) \\
\hline Interventions & Control: usual care \\
\hline
\end{tabular}


Heiman 2004 (Continued)

Duration of intervention: 7 months

Outcomes Quality of care: completion rate of any advanced directives (primary); discussion or completion rate of advanced directives; completion rate of healthcare proxy; completion rate of living will

Clinical area and targeted Advance directives (professional-patient communication) activity

Reminder Description: Reminders were printed at the bottom of patient summary sheets at every patient visit during the study period. It read: "Your patient is $x$ years old with a history of y medical condition and is missing key information about advanced directives". It instructed physicians to enter data about discussion or completion of the living will and healthcare proxy in either the inpatient or the outpatient electronic medical record. Reminders were already in use for screening tests.

Typology: patient-specific: YES; space for response: YES; explicit advice: YES; explanation: NO; reference: NO; at point-of-care: YES

Notes Additional study intervention excluded from analyses: physician reminder; patient reminder; patient
educational material

\section{Risk of bias}

\begin{tabular}{|c|c|c|}
\hline Bias & Authors' judgement & Support for judgement \\
\hline $\begin{array}{l}\text { Random sequence genera- } \\
\text { tion (selection bias) }\end{array}$ & Low risk & $\begin{array}{l}\text { "A blinded programmer using a random number generator randomly assigned } \\
\text { each group" }\end{array}$ \\
\hline $\begin{array}{l}\text { Allocation concealment } \\
\text { (selection bias) }\end{array}$ & Low risk & $\begin{array}{l}\text { "A blinded programmer using a random number generator randomly assigned } \\
\text { each group" }\end{array}$ \\
\hline $\begin{array}{l}\text { Blinding of outcome as- } \\
\text { sessment (detection bias) } \\
\text { All outcomes }\end{array}$ & High risk & "The study investigator who assessed outcomes was not blinded". \\
\hline $\begin{array}{l}\text { Incomplete outcome data } \\
\text { (attrition bias) } \\
\text { All outcomes }\end{array}$ & Low risk & $\begin{array}{l}\text { Among the } 950 \text { randomized patients, } 41 \text { were ineligible ( } 17 \text { [3.4\%] in interven- } \\
\text { tion group and } 24 \text { [5.4\%] in control group) and } 190 \text { refused to participate (102 } \\
{[20.2 \%] \text { in intervention group and } 88[19.7 \%] \text { in control group). In total, } 719} \\
{[75.7 \%] \text { were included in the intention-to-treat analyses ( } 385[76.4 \%] \text { in inter- }} \\
\text { vention group and } 334[74.9 \%] \text { in control group). }\end{array}$ \\
\hline $\begin{array}{l}\text { Selective reporting (re- } \\
\text { porting bias) }\end{array}$ & Unclear risk & not clear \\
\hline Other bias & Unclear risk & not clear \\
\hline $\begin{array}{l}\text { Outcomes at baseline sim- } \\
\text { ilar? }\end{array}$ & Unclear risk & Not reported \\
\hline $\begin{array}{l}\text { Characteristics at baseline } \\
\text { similar? }\end{array}$ & High risk & $\begin{array}{l}\text { significant differences at baseline for age, gender, private insurance, and num- } \\
\text { ber of qualifying illnesses }\end{array}$ \\
\hline $\begin{array}{l}\text { Adequate protection } \\
\text { against contamination? }\end{array}$ & Low risk & physicians randomized \\
\hline
\end{tabular}


Javitt 2005

\begin{tabular}{|c|c|}
\hline Methods & Randomized trial, unit of allocation: patient \\
\hline \multirow[t]{3}{*}{ Participants } & $\begin{array}{l}\text { Patients: all members of a managed care plan, } 12-64 \text { years old; women: } 58 \% \text {; mean age: } 38, n=41,870 \\
{[35,447 \text { completed study] ( } n=\text { not clear for included analyses) }}\end{array}$ \\
\hline & Professionals: not clear \\
\hline & Setting: mixed (managed care plan, USA) \\
\hline
\end{tabular}

Interventions

Control: usual care

Intervention: physician reminder

Duration of intervention: 12 months

Outcomes

Quality of care: compliance rate with starting a new drug (primary) (other outcomes not available)

Resource use/cost: mean hospital admissions; mean inpatient days; mean length of stay; inpatient charges

Clinical area and targeted General management: increase compliance with evidence-based practices (prescribing) activity

Reminder

Description: The sentinel system is designed as a rule-based artificial intelligence engine combined with an automated message generator that conveys clinical recommendations and supporting literature to treating physicians. Daily data inputs include physician-generated insurance claims, hospital discharge and outpatient claims, laboratory claims and laboratory test results, and pharmacy claims. Typical issues targeted by the rules engine include the following: a) absence of ACE inhibitor therapy in patients with congestive heart failure and in those who meet the HOPE trial criteria; b) absence of $\beta$ blocker use in patients with myocardial infarction; $c$ ) absence of anticoagulation in patients with atrial fibrillation and structural heart disease; d) absence of documented laboratory monitoring in patients taking warfarin sodium, glitazones, and other medications that require specific laboratory tests. The system contains more than 1000 decision matrices that, when triggered, result in the transmission of a communication to the treating physician (on paper). All recommendations make clear that the communication is merely for the physician's consideration and that there may be mitigating circumstances that might render the recommendation inappropriate.

Typology: patient-specific: YES; space for response: NO; explicit advice: YES; explanation: NOT CLEAR; reference: NO; at point-of-care: YES

Notes

\title{
Risk of bias
}

\begin{tabular}{lll}
\hline Bias & Authors' judgement & Support for judgement \\
\hline $\begin{array}{ll}\text { Random sequence genera- } \\
\text { tion (selection bias) }\end{array}$ & Low risk & $\begin{array}{l}\text { "Patients were assigned to an intervention or a control group, using an individ- } \\
\text { ually assigned random number. Assignment occurred on a single date at study } \\
\text { entry." }\end{array}$
\end{tabular}

Allocation concealment Low risk
(selection bias)

\begin{abstract}
"Assignment occurred on a single date at study entry. Neither patients nor treating physicians were informed of the allocation, although it is likely that physicians who received communications about specific patients surmised that those patients were part of the intervention group."
\end{abstract}

Blinding of outcome as- Unclear risk Not specified in article. Likely from a computer database. sessment (detection bias) All outcomes 
Javitt 2005 (Continued)

\begin{tabular}{|c|c|c|}
\hline $\begin{array}{l}\text { Incomplete outcome data } \\
\text { (attrition bias) } \\
\text { All outcomes }\end{array}$ & Low risk & $\begin{array}{l}41870 \text { patients randomized - } 2408 \text { withdrew before study inception (1206 } \\
\text { [5.9\%] in control group and } 1202[5.8 \%] \text { in intervention group) - } 4015 \text { withdrew } \\
\text { between } 6 \text { and } 12 \text { months ( } 2088[10 \%] \text { in control group and } 1927[9.2 \%] \text { in in- } \\
\text { tervention group) }=35447 \text { [84.7\%] completed study (17635 [84.3\%] in control } \\
\text { group and } 17812[85.1 \%] \text { in intervention group) }\end{array}$ \\
\hline $\begin{array}{l}\text { Selective reporting (re- } \\
\text { porting bias) }\end{array}$ & Unclear risk & not clear \\
\hline Other bias & Unclear risk & not clear \\
\hline $\begin{array}{l}\text { Outcomes at baseline sim- } \\
\text { ilar? }\end{array}$ & Unclear risk & not reported \\
\hline $\begin{array}{l}\text { Characteristics at baseline } \\
\text { similar? }\end{array}$ & Low risk & $\begin{array}{l}\text { "at baseline, no significant differences were observed in age or sex between } \\
\text { the intervention and control group subjects" }\end{array}$ \\
\hline $\begin{array}{l}\text { Adequate protection } \\
\text { against contamination? }\end{array}$ & High risk & physicians likely care for patients in intervention and control group \\
\hline
\end{tabular}

\section{Le Breton 2016}

Methods Cluster-randomized trial, unit of allocation: health professional $(n=144)$

Participants Patients: age 50-74, registered with a study provider and visited a study provider during study period; women: $55.8 \%$; median age: $60 ; \mathrm{n}=20788$

Professionals: 144 general practitioners

Setting: outpatient (individual or group primary care practices, Val-de-Marne, France)

\begin{tabular}{ll}
\hline Interventions & Control: usual care \\
& Intervention: physician reminder \\
& Duration of intervention: 17 months
\end{tabular}

Outcomes

Quality of care: unadjusted patient adherence to colorectal cancer screening (completion of FOBT or exclusion from FOBT for medical reason), adjusted patient adherence (adjusted for clustering)

\section{Clinical area and targeted Preventive care/colorectal cancer (test ordering) activity}

Reminder The screening centre mailed three reminders to the intervention-group GPs at 4-month intervals. The
reminders were lists of patients who had not performed a scheduled FOBT.

Typology: patient-specific: YES; space for response: NO; explicit advice: YES; explanation: NO; reference: NO; at point-of-care: NO

Notes

\section{Risk of bias}


Le Breton 2016 (Continued)

$\begin{aligned} & \text { Random sequence genera- } \\ & \text { tion (selection bias) }\end{aligned} \quad \begin{aligned} & \text { "GPs were assigned randomly in a 1:1 proportion to the intervention or the } \\ & \text { control group, in permuted blocks of } 2 \text { or } 4 "\end{aligned}$
tion (selection bias) control group, in permuted blocks of 2 or 4 "

\begin{tabular}{|c|c|c|}
\hline $\begin{array}{l}\text { Allocation concealment } \\
\text { (selection bias) }\end{array}$ & Low risk & unit of allocation by professional (GP) \\
\hline $\begin{array}{l}\text { Blinding of outcome as- } \\
\text { sessment (detection bias) } \\
\text { All outcomes }\end{array}$ & Low risk & $\begin{array}{l}\text { "Outcome data were collected for all patients in the ADOC } 94 \text { database } \\
\text { throughout the study period and over the 9-month period following the last re- } \\
\text { minder by data abstracters who were blinded to group assignment." }\end{array}$ \\
\hline $\begin{array}{l}\text { Incomplete outcome data } \\
\text { (attrition bias) } \\
\text { All outcomes }\end{array}$ & Low risk & $\begin{array}{l}\text { "We included } 20778 \text { patients who were eligible for CRC screening and had vis- } \\
\text { ited a study GP for any reason during the study period". No missing data. See } \\
\text { Figure } 1 \text { in paper. }\end{array}$ \\
\hline $\begin{array}{l}\text { Selective reporting (re- } \\
\text { porting bias) }\end{array}$ & Low risk & $\begin{array}{l}\text { Primary outcome in trial register matches the primary outcome in the pub- } \\
\text { lished paper. }\end{array}$ \\
\hline Other bias & Unclear risk & $\begin{array}{l}\text { Low GP participation rate. Only } 15 \% \text { of contacted GPs agreed to participate in } \\
\text { the study. }\end{array}$ \\
\hline
\end{tabular}

Outcomes at baseline sim- Low risk

No SS difference at baseline. "CRC screening adherence rates were $21.8 \%$ (95\% ilar? $\mathrm{Cl} 18.7-26.1)$ in the intervention group and $21.9 \%(95 \% \mathrm{Cl} 18.9-26.5)$ in the control group."

\begin{tabular}{|c|c|c|}
\hline $\begin{array}{l}\text { Characteristics at baseline } \\
\text { similar? }\end{array}$ & High risk & $\begin{array}{l}\text { Some SS differences. "Baseline GP characteristics were similar in the two } \\
\text { groups, except for numbers of GPs in group practice and charging above-stan- } \\
\text { dard fees, which were higher in the control group. The only significant differ- } \\
\text { ence in baseline patient characteristics was a slightly higher proportion of pa- } \\
\text { tients from deprived areas in the intervention group." }\end{array}$ \\
\hline
\end{tabular}

\begin{tabular}{ll}
\hline $\begin{array}{l}\text { Adequate protection } \\
\text { against contamination? }\end{array}$ & Low risk Randomization at the GP level. Low risk of contamination. \\
\hline
\end{tabular}

Lobach 1997

\begin{tabular}{ll}
\hline Methods & Cluster-randomized trial, unit of allocation: health professional \\
\hline Participants & Patients: diabetic; $\mathrm{n}=497$ eligible patients (359 analyzed); encounters: 1265 (884 analyzed) \\
& $\begin{array}{l}\text { Professionals: } 58 \text { primary care providers randomized (20 family physicians, } 1 \text { general internist, } 2 \text { physi- } \\
\text { cian's assistants, } 2 \text { nurse practitioners, } 33 \text { residents) [30 analyzed] }\end{array}$ \\
& Setting: outpatient (Duke Family Medicine Center, USA) \\
\hline Interventions & Control: usual care \\
& $\begin{array}{l}\text { Intervention: physician reminder } \\
\text { Duration of intervention: six months }\end{array}$ \\
\hline $\begin{array}{l}\text { Quality of care: clinician compliance rate overall (number of recommendations completed/total num- } \\
\text { ber of recommendations) (primary); clinician compliance rate for } 8 \text { recommendations: foot exam every } \\
\text { month in patients with diabetic neuropathy or history of lower limb ulcer, annual complete physical ex- } \\
\text { am, glycated hemoglobin every } 6 \text { months, annual urine protein determination, annual cholesterol lev- } \\
\text { el, annual eye exam, seasonal influenza vaccination, pneumococcal vaccination }\end{array}$
\end{tabular}


Lobach 1997 (Continued)

Clinical area and targeted activity

Reminder
Diabetes (multiple: test ordering, vaccination)

Description: The Computer-Assisted Management Protocol generates a set of disease-specific care recommendations customized to an individual patient, based on data stored in the patient's electronic medical record, that advises the clinician regarding which studies/procedures should be done during the current visit and which studies/procedures are next due in order to assist the clinician with managing the diabetic patient in accordance with a clinical practice guideline. The output is printed on the 1st page of the paper encounter form. Additional flexibility is included for the clinicians to designate that the recommendation was declined by the patient ("D") or never to be done for the patient ("N"). Clinicians can order the appropriate studies/procedures on the encounter form and indicate results of procedures done during the encounter.

Typology: patient-specific: YES; space for response: YES; explicit advice: YES; explanation: YES; reference: NO; at point-of-care: YES

Notes

\section{Risk of bias}

\begin{tabular}{|c|c|c|}
\hline Bias & Authors' judgement & Support for judgement \\
\hline $\begin{array}{l}\text { Random sequence genera- } \\
\text { tion (selection bias) }\end{array}$ & Low risk & $\begin{array}{l}\text { "all primary care providers were randomly assigned by standard randomiza- } \\
\text { tion techniques" }\end{array}$ \\
\hline $\begin{array}{l}\text { Allocation concealment } \\
\text { (selection bias) }\end{array}$ & Low risk & $\begin{array}{l}\text { "all primary care providers were randomly assigned by standard randomiza- } \\
\text { tion techniques" }\end{array}$ \\
\hline $\begin{array}{l}\text { Blinding of outcome as- } \\
\text { sessment (detection bias) } \\
\text { All outcomes }\end{array}$ & Low risk & "chart audit with audit protocol: intra-auditor consistency > 90\%" \\
\hline $\begin{array}{l}\text { Incomplete outcome data } \\
\text { (attrition bias) } \\
\text { All outcomes }\end{array}$ & Low risk & \\
\hline $\begin{array}{l}\text { Selective reporting (re- } \\
\text { porting bias) }\end{array}$ & Unclear risk & not clear \\
\hline Other bias & Unclear risk & not clear \\
\hline $\begin{array}{l}\text { Outcomes at baseline sim- } \\
\text { ilar? }\end{array}$ & Low risk & "compliance scores prior to study were not statistically significantly different" \\
\hline $\begin{array}{l}\text { Characteristics at baseline } \\
\text { similar? }\end{array}$ & Low risk & "patients did not differ significantly by age, race or gender" \\
\hline $\begin{array}{l}\text { Adequate protection } \\
\text { against contamination? }\end{array}$ & Low risk & providers randomized \\
\hline
\end{tabular}

\section{Majumdar 2007}

\begin{tabular}{ll}
\hline Methods & Cluster-randomized trial; unit of allocation: health professional \\
\hline Participants & Patients: patients with heart failure or with ischemic heart disease; women: $60 \% ;$ median age: $75 ; n=$ \\
& 171
\end{tabular}

Computer-generated reminders delivered on paper to healthcare professionals: effects on professional practice and healthcare outcomes 
Majumdar 2007 (Continued)

Professionals: primary care physicians, $n=769$ potentially eligible randomized (128 analyzed)

Setting: outpatient (Alberta, Canada)

$\begin{array}{ll}\text { Interventions } & \text { Active control: medication profile } \\ \text { Intervention: physician reminder; medication profile } \\ \text { Duration of intervention: } 3.5 \text { year }\end{array}$

Outcomes

Quality of care: prescription rate of efficacious therapies within 6 months (primary); prescription rate of ACE inhibitors or ARBs in heart failure patients; prescription rate of statins in ischemic heart disease patients

\section{Clinical area and targeted Cardiovascular disease (prescribing)} activity

Description: For each patient, a condition-specific one-page evidence summary was generated in the
form of a letter addressed to the primary care physician and was faxed to him. The letters identified pa-
tients and their diagnoses, briefly described the key evidence in support of the study medications, and
were signed by opinion leaders. The intent of the intervention was that the evidence summary (and
medical profile) would become part of the patient's medical record and act as a point-of-care reminde
for the next patient visit.
Typology: patient-specific: YES; space for response: NO; explicit advice: YES; explanation: YES; refer-
ence: YES; at point-of-care: NO

Notes

\section{Risk of bias}

\begin{tabular}{|c|c|c|}
\hline Bias & Authors' judgement & Support for judgement \\
\hline $\begin{array}{l}\text { Random sequence genera- } \\
\text { tion (selection bias) }\end{array}$ & Low risk & $\begin{array}{l}\text { "simple randomization with concealment of allocation was performed with } \\
\text { the use of a computer-generated sequence" }\end{array}$ \\
\hline $\begin{array}{l}\text { Allocation concealment } \\
\text { (selection bias) }\end{array}$ & Low risk & $\begin{array}{l}\text { "simple randomization with concealment of allocation was performed with } \\
\text { the use of a computer-generated sequence" }\end{array}$ \\
\hline $\begin{array}{l}\text { Blinding of outcome as- } \\
\text { sessment (detection bias) } \\
\text { All outcomes }\end{array}$ & Low risk & $\begin{array}{l}\text { "all outcomes were ascertained in an independent and blinded fashion, and } \\
\text { allocation was concealed from patients, investigators, data collectors, and an- } \\
\text { alysts" }\end{array}$ \\
\hline $\begin{array}{l}\text { Incomplete outcome data } \\
\text { (attrition bias) } \\
\text { All outcomes }\end{array}$ & Low risk & $\begin{array}{l}\text { "no study patients were lost to follow-up". } 769 \text { professionals were randomized, } \\
\text { but } 128 \text { were analyzed as most did not contribute an eligible patient. }\end{array}$ \\
\hline $\begin{array}{l}\text { Selective reporting (re- } \\
\text { porting bias) }\end{array}$ & High risk & results on secondary outcomes not reported. \\
\hline Other bias & Low risk & not clear \\
\hline $\begin{array}{l}\text { Outcomes at baseline sim- } \\
\text { ilar? }\end{array}$ & Unclear risk & not reported \\
\hline $\begin{array}{l}\text { Characteristics at baseline } \\
\text { similar? }\end{array}$ & Low risk & $\begin{array}{l}\text { "the intervention and control subjects were comparable, with no important } \\
\text { differences" }\end{array}$ \\
\hline
\end{tabular}

Computer-generated reminders delivered on paper to healthcare professionals: effects on professional practice and healthcare outcomes 
Majumdar 2007 (Continued)
Adequate protection
Low risk
physicians allocated to intervention against contamination?

\section{Mazzuca 1990}

\begin{tabular}{|c|c|}
\hline Methods & Cluster non-randomized trial; unit of allocation: clinical area, $n=4$ \\
\hline \multirow[t]{3}{*}{ Participants } & $\begin{array}{l}\text { Patients: patients with non-insulin dependent diabetes mellitus; women: not clear; mean age: not } \\
\text { clear; total } n=2791 \text { (estimated } 1395 \text { in the } 2 \text { included study arms) }\end{array}$ \\
\hline & $\begin{array}{l}\text { Professionals: } 99 \text { internal medicine residents and } 15 \text { faculty internists (total } n=114 \text { ) in four clinical ar- } \\
\text { eas (estimated } 57 \text { in the } 2 \text { included study arms) }\end{array}$ \\
\hline & Setting: outpatient (4 clinic areas of a general medicine clinic, Indiana University, USA) \\
\hline \multirow[t]{3}{*}{ Interventions } & Active control: educational meeting (postgraduate seminar) \\
\hline & Intervention: physician reminder; educational meeting (postgraduate seminar) \\
\hline & Duration of intervention: 11 months \\
\hline
\end{tabular}

\begin{tabular}{ll}
\hline Outcomes & Quality of care: adherence rate to recommendations for: lab orders (glycated hemoglobin, fasting \\
blood glucose) and therapies (home-monitored blood glucose, diet clinic referral, oral hypoglycemic \\
agents) (median)
\end{tabular}

Clinical area and targeted Diabetes (multiple: test ordering, prescribing, referral)

activity
Reminder
Description: Printed reminders were placed in patients' clinic records whenever the computer detect- ed history, physical, laboratory, or pharmacy data indicating the need to consider a recommendation (e.g. if the patient was obese and without a diet on record, the computer would print out the following reminder on a separate sheet). (same system as McDonald 1984)
Typology: patient-specific: YES; space for response: NO; explicit advice: YES; explanation: NOT CLEAR; reference: NO; at point-of-care: YES

$\begin{array}{ll}\text { Notes } & \text { Additional study interventions excluded from analyses: a) physician reminder; educational meeting } \\ \text { (postgraduate seminar); physician educational material; b) physician reminder; educational meeting } \\ \text { (postgraduate seminar); physician educational material; patient education service }\end{array}$

\section{Risk of bias}

\begin{tabular}{lll}
\hline Bias & Authors' judgement & Support for judgement \\
\hline $\begin{array}{l}\text { Random sequence genera- } \\
\text { tion (selection bias) }\end{array}$ & High risk & $\begin{array}{l}\text { "the four areas were assigned arbitrarily to study conditions according to a } \\
\text { nonequivalent control group design" }\end{array}$ \\
\hline $\begin{array}{l}\text { Allocation concealment } \\
\text { (selection bias) }\end{array}$ & High risk & $\begin{array}{l}\text { "the four areas were assigned arbitrarily to study conditions according to a } \\
\text { nonequivalent control group design" }\end{array}$ \\
\hline $\begin{array}{l}\text { Blinding of outcome as- } \\
\text { sessment (detection bias) } \\
\text { All outcomes }\end{array}$ & Low risk & "computerized audit of medical record" \\
\hline $\begin{array}{l}\text { Incomplete outcome data } \\
\text { (attrition bias) } \\
\text { All outcomes }\end{array}$ & Unclear risk & not clear \\
\hline \hline
\end{tabular}

Computer-generated reminders delivered on paper to healthcare professionals: effects on professional practice and healthcare outcomes 
Mazzuca 1990 (Continued)

Selective reporting (re- Unclear risk not clear
porting bias)

\begin{tabular}{lll}
\hline Other bias & Unclear risk & not clear \\
\hline $\begin{array}{l}\text { Outcomes at baseline sim- } \\
\text { ilar? }\end{array}$ & Low risk & $\begin{array}{l}\text { "baseline interviews with a random sample of 175 patients showed the 4 } \\
\text { groups to be equivalent with respect to general therapeutic practices" }\end{array}$ \\
\hline $\begin{array}{l}\text { Characteristics at baseline } \\
\text { similar? }\end{array}$ & Unclear risk & not clear \\
\hline $\begin{array}{l}\text { Adequate protection } \\
\text { against contamination? }\end{array}$ & Low risk & randomization by clinical area \\
\hline
\end{tabular}

\section{McAlister 2009}

\begin{tabular}{ll}
\hline Methods & Cluster-randomized trial, unit of allocation: health professional \\
\hline Participants & Patients: $>18$ years old, diagnosed with coronary artery disease (stenosis in at least one coronary ves- \\
sel of $\geq 50 \%$ ) eligible for but not already taking a statin or who were on a suboptimal regimen, women: \\
$21 \%$, mean age: $64, \mathrm{n}=480$ \\
Professionals: primary care physicians, $\mathrm{n}=252$ \\
Setting: outpatient (252 general practices in Alberta, Canada) \\
\hline
\end{tabular}

Interventions

\section{Active control: coronary artery diagram}

Intervention (two intervention arms combined): coronary artery diagram; physician reminder

Duration of intervention: 6 months

Outcomes
(primary); taking a statin; standardized statin dose; taking another lipid-lowering drug; acetylsalicylic
acid; acetylsalicylic acid or thienopyridine; ACE inhibitor; ACE inhibitor or ARB; $\beta$-Blocker; triple therapy
Patient outcomes: mortality rate
Resource use/cost: ED visits, hospitalizations

\section{Clinical area and targeted Cardiovascular disease (prescribing)} activity

Description: The statement was a 1-page summary of evidence-based secondary prevention strategies and treatment recommendations. The Local Opinion Leader Statement contained the signatures of 5 local opinion leaders, while the Unsigned Evidence Statement was unsigned. These statements were imprinted with the name of the patient, addressed directly to the patient's physician, and faxed automatically by a software program, along with a coronary artery diagram documenting the extent of the patient's coronary atherosclerosis. These statements were sent to physicians within a few days of the angiogram.

Typology: patient-specific: YES; space for response: NO; explicit advice: YES; explanation: YES; reference: YES for intervention a/NO for intervention b; at point-of-care: NO

Notes Intervention a: coronary artery diagram; physician reminder (local opinion leader statement)
Intervention b: coronary artery diagram; physician reminder (unsigned evidence statement)


McAlister 2009 (Continued)

Intervention groups considered separately in 1 analysis (content of reminder: reference versus no reference)

\begin{tabular}{|c|c|c|}
\hline \multicolumn{3}{|l|}{ Risk of bias } \\
\hline Bias & Authors' judgement & Support for judgement \\
\hline $\begin{array}{l}\text { Random sequence genera- } \\
\text { tion (selection bias) }\end{array}$ & Low risk & $\begin{array}{l}\text { "computer-generated central randomization system with concealment of the } \\
\text { randomization list" }\end{array}$ \\
\hline $\begin{array}{l}\text { Allocation concealment } \\
\text { (selection bias) }\end{array}$ & Low risk & $\begin{array}{l}\text { "computer-generated central randomization system with concealment of the } \\
\text { randomization list" }\end{array}$ \\
\hline $\begin{array}{l}\text { Blinding of outcome as- } \\
\text { sessment (detection bias) } \\
\text { All outcomes }\end{array}$ & Low risk & "Blinding of outcome assessors and analysts" \\
\hline $\begin{array}{l}\text { Incomplete outcome data } \\
\text { (attrition bias) } \\
\text { All outcomes }\end{array}$ & Low risk & reasons provided for excluded patients; intention-to-treat analyses \\
\hline $\begin{array}{l}\text { Selective reporting (re- } \\
\text { porting bias) }\end{array}$ & Low risk & outcomes reported match outcomes described in protocol \\
\hline Other bias & Low risk & no recruitment bias; GEE analyses \\
\hline $\begin{array}{l}\text { Outcomes at baseline sim- } \\
\text { ilar? }\end{array}$ & Low risk & $\begin{array}{l}\text { "No appreciable differences between the treatment arms" for statin use }(P= \\
0-87) \text { and statin dosing }(P=0.84)\end{array}$ \\
\hline $\begin{array}{l}\text { Characteristics at baseline } \\
\text { similar? }\end{array}$ & Low risk & $\begin{array}{l}\text { "At baseline, there were no statistically significant differences between } \\
\text { groups". }\end{array}$ \\
\hline $\begin{array}{l}\text { Adequate protection } \\
\text { against contamination? }\end{array}$ & Low risk & randomization by health professional \\
\hline
\end{tabular}

\section{McDonald 1976a}

\begin{tabular}{ll}
\hline Methods & Cluster non-randomized trial (cross-over), unit of allocation: health professional \\
\hline Participants & Patients: percentage of women: not clear, mean age: not clear, $\mathrm{n}=189$ \\
& Professionals: physicians, $\mathrm{n}=9$ \\
& Setting: outpatient care (general medicine clinic at Wishard Memorial Hospital, Indianapolis, USA) \\
\hline Interventions & Control: usual care \\
& Intervention: physician reminder \\
& Duration of intervention: 17 weeks \\
\hline Outcomes & $\begin{array}{l}\text { Quality of care: overall compliance rate (primary); compliance rate with observing a physical finding or } \\
\text { inquiring about a symptom; compliance with ordering a diagnostic study; compliance with changing or } \\
\text { initiating a therapeutic regimen }\end{array}$ \\
\hline
\end{tabular}

\section{Clinical area and targeted General care (multiple: prescribing, test ordering, other)} activity 
McDonald 1976a (Continued)

Reminder
Description: The Regenstrief Medical records system searches its records for events and makes recommendations about the management. Each recommendation consists of a reminder to the physician that a particular event has occurred and a suggested course of "action" for correcting that event. The study involved 390 protocols (recommendations). The computer prints 3 reports. The first is the surveillance report, which contains all the computer recommendations for a given patient. The second is a computer-tailored encounter form, which provides space for recording findings. The third report, the summary report, is not influenced by the computer protocols and is a flow-sheet summary.

Typology: patient-specific: YES; space for response: YES; explicit advice: YES; explanation: YES; reference: NO; at point-of-care: YES

\section{Notes}

\section{Risk of bias}

\begin{tabular}{|c|c|c|}
\hline Bias & Authors' judgement & Support for judgement \\
\hline $\begin{array}{l}\text { Random sequence genera- } \\
\text { tion (selection bias) }\end{array}$ & High risk & no mention of randomization \\
\hline $\begin{array}{l}\text { Allocation concealment } \\
\text { (selection bias) }\end{array}$ & High risk & not described \\
\hline $\begin{array}{l}\text { Blinding of outcome as- } \\
\text { sessment (detection bias) } \\
\text { All outcomes }\end{array}$ & Unclear risk & $\begin{array}{l}\text { outcome data gathered through medical record review, no indication of blind- } \\
\text { ing }\end{array}$ \\
\hline $\begin{array}{l}\text { Incomplete outcome data } \\
\text { (attrition bias) } \\
\text { All outcomes }\end{array}$ & Unclear risk & not clear \\
\hline $\begin{array}{l}\text { Selective reporting (re- } \\
\text { porting bias) }\end{array}$ & Unclear risk & not clear \\
\hline Other bias & Unclear risk & not clear \\
\hline $\begin{array}{l}\text { Outcomes at baseline sim- } \\
\text { ilar? }\end{array}$ & Unclear risk & not reported \\
\hline $\begin{array}{l}\text { Characteristics at baseline } \\
\text { similar? }\end{array}$ & Unclear risk & not reported \\
\hline $\begin{array}{l}\text { Adequate protection } \\
\text { against contamination? }\end{array}$ & High risk & cross-over design \\
\hline
\end{tabular}

McDonald 1976b

\begin{tabular}{ll}
\hline Methods & Randomized trial, unit of allocation: patient \\
\hline Participants & Patients: adult diabetic patients; percentage of women: not clear, mean age: $60, \mathrm{n}=257$ (226 analyzed) \\
& Professionals: diabetologists, residents, interns, senior medical residents, nurse clinicians, $\mathrm{n}=63$ \\
& Setting: outpatient (diabetic clinic of Wishard Memorial Hospital, Indianapolis, USA) \\
\hline Interventions & Control: usual care
\end{tabular}

Computer-generated reminders delivered on paper to healthcare professionals: effects on professional practice and healthcare outcomes 
McDonald 1976b (Continued)

Intervention: physician reminder

Duration of intervention: 8 months

Outcomes

Quality of care: compliance rate with recommendations for test ordering/therapeutical change (median)

Clinical area and targeted activity

Diabetes (multiple: prescribing, test ordering)

Reminder

Description: The computerized medical record system (Regenstrief) generated prospective, protocol-driven recommendations, which alerted the clinician to the existence of, and the proper response to, simple events. Two types of protocols: 1 ) taking measurement at proper intervals, based on "if on $\operatorname{drug} \mathrm{A}$ and no test $\mathrm{B}$ for $\mathrm{X}$ months then order test $\mathrm{B}$; 2 2) reacting to measures that implied that treatment was either insufficient, excessive, or dangerous, based on "if on drug A and last test $B$ abnormal, then warn about possible changed drug action". The computer printed 3 reports: the summary report, with a flow-sheet; the patient encounter form with space for writing new medication orders; the surveillance report, with the protocol-generated suggestions to physician, with recommended tests, date of last test, treatments triggering recommendation, recommendations for specific changes in therapeutics, with rationale for the change suggested.

Typology: patient-specific: YES; space for response: YES; explicit advice: YES; explanation: YES; reference: YES; at point-of-care: YES

Notes

\section{Risk of bias}

\begin{tabular}{|c|c|c|}
\hline Bias & Authors' judgement & Support for judgement \\
\hline $\begin{array}{l}\text { Random sequence genera- } \\
\text { tion (selection bias) }\end{array}$ & Low risk & randomized by computer-generated random number \\
\hline $\begin{array}{l}\text { Allocation concealment } \\
\text { (selection bias) }\end{array}$ & Unclear risk & not described \\
\hline $\begin{array}{l}\text { Blinding of outcome as- } \\
\text { sessment (detection bias) } \\
\text { All outcomes }\end{array}$ & Unclear risk & not clear \\
\hline $\begin{array}{l}\text { Incomplete outcome data } \\
\text { (attrition bias) } \\
\text { All outcomes }\end{array}$ & Unclear risk & not clear \\
\hline $\begin{array}{l}\text { Selective reporting (re- } \\
\text { porting bias) }\end{array}$ & Unclear risk & not clear \\
\hline Other bias & Unclear risk & not clear \\
\hline $\begin{array}{l}\text { Outcomes at baseline sim- } \\
\text { ilar? }\end{array}$ & Unclear risk & not reported \\
\hline $\begin{array}{l}\text { Characteristics at baseline } \\
\text { similar? }\end{array}$ & Unclear risk & not reported \\
\hline $\begin{array}{l}\text { Adequate protection } \\
\text { against contamination? }\end{array}$ & High risk & most practitioners saw patients from both the study and control groups \\
\hline
\end{tabular}


McDonald 1980

Methods Cluster-randomized trial (cross-over trial), unit of allocation: health professional

Participants Patients: $\mathrm{n}=$ not clear; conditions: 3691

Professionals: 31 providers (9 interns, 17 residents, 5 nurse-practitioners)

Setting: outpatient (General medicine service, University Hospital, Indianapolis, USA)

\begin{tabular}{ll}
\hline Interventions & Control: usual care \\
& Intervention ( 2 intervention arms combined): physician reminder \\
& Duration of intervention: 15 weeks
\end{tabular}

Duration of intervention: 15 weeks

Outcomes Quality of care: compliance rate

Clinical area and targeted Preventive care (multiple: test ordering, prescribing, general management) activity

\begin{tabular}{|c|c|}
\hline Reminder & $\begin{array}{l}\text { Description: At each visit, the computer provides a tailored encounter form and a flow sheet summa- } \\
\text { ry of each patient's medical history and follows physician-authored management rules }(n=410) \text { to re- } \\
\text { mind the physician about patient conditions requiring his attention. The report containing these re- } \\
\text { minders is called the "surveillance" report. Practitioners order all diagnostic treatments and referrals } \\
\text { by recording them on the encounter form. }\end{array}$ \\
\hline & $\begin{array}{l}\text { Typology: patient-specific: YES; space for response: YES; explicit advice: YES; explanation: YES; refer- } \\
\text { ence: YES for intervention a / NO for intervention b; at point-of-care: YES }\end{array}$ \\
\hline \multirow[t]{3}{*}{ Notes } & Intervention a: physician reminder (with bibliographic citations) \\
\hline & Intervention b: physician reminder (without citations) \\
\hline & $\begin{array}{l}\text { Intervention groups considered separately in } 1 \text { analysis (content of reminder: reference versus no refer- } \\
\text { ence) }\end{array}$ \\
\hline
\end{tabular}

\section{Risk of bias}

\begin{tabular}{lll}
\hline Bias & Authors' judgement & Support for judgement \\
\hline $\begin{array}{l}\text { Random sequence genera- } \\
\text { tion (selection bias) }\end{array}$ & Unclear risk & $\begin{array}{l}\text { physicians were randomly assigned to the order to which they received their } \\
\text { intervention }\end{array}$ \\
\hline $\begin{array}{l}\text { Allocation concealment } \\
\text { (selection bias) }\end{array}$ & Unclear risk & not described \\
\hline $\begin{array}{l}\text { Blinding of outcome as- } \\
\text { sessment (detection bias) } \\
\text { All outcomes }\end{array}$ & Unclear risk & not clear \\
\hline $\begin{array}{l}\text { Incomplete outcome data } \\
\text { (attrition bias) }\end{array}$ & Unclear risk & not clear \\
$\begin{array}{l}\text { All outcomes } \\
\text { Selective reporting (re- } \\
\text { porting bias) }\end{array}$ & Unclear risk & not clear \\
\hline \begin{tabular}{l} 
Other bias \\
\hline
\end{tabular} & Unclear risk & not clear \\
\hline
\end{tabular}

Computer-generated reminders delivered on paper to healthcare professionals: effects on professional practice and healthcare outcomes 
McDonald 1980 (Continued)

\begin{tabular}{lll}
$\begin{array}{l}\text { Outcomes at baseline sim- } \\
\text { ilar? }\end{array}$ & Unclear risk & not reported \\
\hline $\begin{array}{l}\text { Characteristics at baseline } \\
\text { similar? }\end{array}$ & Unclear risk & not reported \\
\hline $\begin{array}{l}\text { Adequate protection } \\
\text { against contamination? }\end{array}$ & High risk & cross-over trial \\
\hline
\end{tabular}

McDonald 1984

\begin{tabular}{|c|c|}
\hline Methods & Cluster-randomized trial, unit of allocation: practice team, $n=27$ \\
\hline \multirow[t]{3}{*}{ Participants } & Patients: women: $65 \%$; mean age: not clear; $n=12,467$ \\
\hline & $\begin{array}{l}\text { Professionals: } 130 \text { providers ( } 115 \text { residents, } 11 \text { faculty, } 4 \text { nurses) within practice teams ( } n=115 \text { in in- } \\
\text { cluded study groups) }\end{array}$ \\
\hline & Setting: outpatient (27 teams in a general medicine service, University Hospital, Indianapolis USA) \\
\hline
\end{tabular}

\begin{tabular}{ll}
\hline Interventions & Control: usual care \\
& Intervention: physician reminder \\
Duration of intervention: 2 years
\end{tabular}

Quality of care: overall compliance rate (primary); compliance with occult blood, cervical smear, chest
roentgenogram, pneumococcal vaccine, tuberculosis skin test, serum potassium, mammogram, in-
fluenza vaccine, diet, digitalis, antacids, beta blockers (12 reminders)

Clinical area and targeted Preventive care (multiple: vaccination, test ordering, prescribing) activity

Description: The computerized medical record was programmed with 1491 rules that could generate
751 different reminder messages. The set of rules included reminders about preventive care, obtaining
tests needed to complete the initial database or to identify the cause of existing abnormalities, about
prophylactic treatment and treatment of active problems. The computer used these rules to review
each patient's electronic medical record the day before each visit. For each patient, when it found con-
ditions satisfying the reminder rule, a reminder was stored on a disc file. The computer gathered these
messages as a printed report that was attached to the charts of scheduled patients. The reminder mes-
sages included citations to the relevant medical literature.
Typology: patient-specific: YES; space for response: YES; explicit advice: YES; explanation: YES; refer-
ence: YES; at point-of-care: YES

Notes

\section{Risk of bias}

\begin{tabular}{lll}
\hline Bias & Authors' judgement & Support for judgement \\
\hline $\begin{array}{l}\text { Random sequence genera- } \\
\text { tion (selection bias) }\end{array}$ & Unclear risk & "Each team was randomized as to study or control" \\
\hline $\begin{array}{l}\text { Allocation concealment } \\
\text { (selection bias) }\end{array}$ & Unclear risk & not described \\
\hline
\end{tabular}


McDonald 1984 (Continued)

Blinding of outcome as- Low risk outcomes measured using computer sessment (detection bias)

All outcomes

\begin{tabular}{|c|c|c|}
\hline $\begin{array}{l}\text { Incomplete outcome data } \\
\text { (attrition bias) } \\
\text { All outcomes }\end{array}$ & Low risk & $\begin{array}{l}\text { physicians with fewer than } 100 \text { reminder messages during study period ex- } \\
\text { cluded }(2 \%)\end{array}$ \\
\hline $\begin{array}{l}\text { Selective reporting (re- } \\
\text { porting bias) }\end{array}$ & Unclear risk & not clear \\
\hline Other bias & Unclear risk & not clear \\
\hline $\begin{array}{l}\text { Outcomes at baseline sim- } \\
\text { ilar? }\end{array}$ & Unclear risk & Not reported \\
\hline $\begin{array}{l}\text { Characteristics at baseline } \\
\text { similar? }\end{array}$ & Low risk & No significant difference in gender and age for patients \\
\hline $\begin{array}{l}\text { Adequate protection } \\
\text { against contamination? }\end{array}$ & Unclear risk & $\begin{array}{l}\text { practice team randomized, but faculty members and nurse-clinicians saw both } \\
\text { study groups }\end{array}$ \\
\hline
\end{tabular}

McPhee 1989

\begin{tabular}{|c|c|}
\hline Methods & Cluster-randomized trial, unit of allocation: health professional \\
\hline \multirow[t]{3}{*}{ Participants } & $\begin{array}{l}\text { Patients: } \geq 40 \text { years old, women: } 67 \% \text {, mean age: } \text { not clear; } n=\sim 1291 \text { patients in four included study } \\
\text { arms }\end{array}$ \\
\hline & Professionals: 42 residents in four included study arms \\
\hline & Setting: outpatient (General Internal Medicine Practice, University hospital, San Francisco USA) \\
\hline \multirow[t]{5}{*}{ Interventions } & Control (comparison 1): usual care \\
\hline & Intervention (comparison 1): physician reminder \\
\hline & Active control (comparison 2): distribution of educational material to patients; patient reminder \\
\hline & $\begin{array}{l}\text { Intervention (comparison 2): physician reminder; distribution of educational material to patients; pa- } \\
\text { tient reminder }\end{array}$ \\
\hline & Duration of intervention: nine months \\
\hline
\end{tabular}

Outcomes

Quality of care: physician compliance rate with: FOBT, rectal exam, sigmoidoscopy, pap smear, pelvic exam, breast exam, and mammography (median)

Cost: cost per patient; cost per additional screening test

Clinical area and targeted Preventive care/colorectal, breast, cervical cancer (test ordering) activity

Reminder

Description: The cancer screening reminders provided residents with up-to-date information about their patient's screening status. The research staff printed cancer screening reminders at the time of each patient appointment and updated existing microcomputer files by re-auditing patient medical records in preparation for return appointments. At the time of a patient's visit to the resident, a cancer screening reminder was attached to the regular encounter form or medical record. A new reminder was generated for each patient encounter. Reminders displayed the list of appropriate cancer screen-

Computer-generated reminders delivered on paper to healthcare professionals: effects on professional practice and healthcare outcomes 
ing procedures (based on the patient's sex and age), the recommended testing intervals, the last performance date, the due date for each next test, and the patient's current "due" status. The physician indicated on the form whether or not each test was performed or ordered during the current visit.

Typology: patient-specific: YES; space for response: YES; explicit advice: YES; explanation: NO; reference: YES; at point-of-care: YES

Dotes $\begin{aligned} & \text { Data extracted from graphics. Author not contacted as publication date }>10 \text { years. } \\ & \text { Additional study interventions excluded from analyses: a) audit and feedback, b) audit and feedback; } \\ & \text { distribution of educational material to patients; patient reminder }\end{aligned}$

\section{Risk of bias}

\begin{tabular}{|c|c|c|}
\hline Bias & Authors' judgement & Support for judgement \\
\hline $\begin{array}{l}\text { Random sequence genera- } \\
\text { tion (selection bias) }\end{array}$ & Unclear risk & "residents were randomly assigned to one of six intervention groups" \\
\hline $\begin{array}{l}\text { Allocation concealment } \\
\text { (selection bias) }\end{array}$ & Unclear risk & not described \\
\hline $\begin{array}{l}\text { Blinding of outcome as- } \\
\text { sessment (detection bias) } \\
\text { All outcomes }\end{array}$ & Low risk & $\begin{array}{l}\text { Medical records audit: no blinding but reliability test performed on random } \\
\text { sample (90-98\%) }\end{array}$ \\
\hline $\begin{array}{l}\text { Incomplete outcome data } \\
\text { (attrition bias) } \\
\text { All outcomes }\end{array}$ & High risk & $\begin{array}{l}1969 \text { records audited at baseline }=72 \% \text { of eligible patients; } 1936 \text { records audit- } \\
\text { ed during study }=71 \% \text { of eligible patients }\end{array}$ \\
\hline $\begin{array}{l}\text { Selective reporting (re- } \\
\text { porting bias) }\end{array}$ & Unclear risk & not clear \\
\hline Other bias & Unclear risk & not clear \\
\hline $\begin{array}{l}\text { Outcomes at baseline sim- } \\
\text { ilar? }\end{array}$ & Low risk & compliance scores at baseline not significantly different \\
\hline $\begin{array}{l}\text { Characteristics at baseline } \\
\text { similar? }\end{array}$ & Unclear risk & not reported \\
\hline $\begin{array}{l}\text { Adequate protection } \\
\text { against contamination? }\end{array}$ & Low risk & providers randomized \\
\hline
\end{tabular}

Morgan 1978

\begin{tabular}{ll}
\hline Methods & Non-randomized trial, unit of allocation: patient \\
\hline Participants & Patients: pregnant women; mean age: not clear, $\mathrm{n}=279$ \\
& Professionals: physicians, $\mathrm{n}=5$ \\
& Setting: outpatient (Harvard Community Health Plan ambulatory care center, Boston, USA) \\
\hline Interventions & Control: usual care \\
& Intervention: physician reminder
\end{tabular}

Computer-generated reminders delivered on paper to healthcare professionals: effects on professional practice and healthcare outcomes 
Morgan 1978 (Continued)

Duration of intervention: 18 months

Outcomes Quality of care: compliance rate with 5 minimum standard of care (at 18months): blood group and type, syphilis serology, prenatal counseling, pregnancy diet counseling, sickle cell preparation (median)

Clinical area and targeted Prenatal care (multiple: test ordering, professional-patient communication) activity

Reminder

Description: COSTAR was programmed to automatically check the records of patients at the time of each prenatal visit to determine if physicians had complied with specific indices of care. An updated summary record was printed prior to the patient's visit with the list of missing items, under the heading "Data incomplete".

Typology: patient-specific: YES; space for response: NO; explicit advice: NO; explanation: NO; reference: NO; at point-of-care: YES

\section{Notes}

\section{Risk of bias}

\begin{tabular}{|c|c|c|}
\hline Bias & Authors' judgement & Support for judgement \\
\hline $\begin{array}{l}\text { Random sequence genera- } \\
\text { tion (selection bias) }\end{array}$ & High risk & $\begin{array}{l}\text { "patients with odd-numbered medical records were assigned to the exper- } \\
\text { imental group (...) patients with even-numbered medical records were as- } \\
\text { signed to a control group". }\end{array}$ \\
\hline $\begin{array}{l}\text { Allocation concealment } \\
\text { (selection bias) }\end{array}$ & High risk & allocation based on odd/even number of medical record \\
\hline $\begin{array}{l}\text { Blinding of outcome as- } \\
\text { sessment (detection bias) } \\
\text { All outcomes }\end{array}$ & Unclear risk & outcomes likely assessed by computer, but no specific indication in text \\
\hline $\begin{array}{l}\text { Incomplete outcome data } \\
\text { (attrition bias) } \\
\text { All outcomes }\end{array}$ & Unclear risk & not clear \\
\hline $\begin{array}{l}\text { Selective reporting (re- } \\
\text { porting bias) }\end{array}$ & Unclear risk & not clear \\
\hline Other bias & Unclear risk & not clear \\
\hline $\begin{array}{l}\text { Outcomes at baseline sim- } \\
\text { ilar? }\end{array}$ & Unclear risk & not reported \\
\hline $\begin{array}{l}\text { Characteristics at baseline } \\
\text { similar? }\end{array}$ & Unclear risk & not reported \\
\hline $\begin{array}{l}\text { Adequate protection } \\
\text { against contamination? }\end{array}$ & High risk & physicians saw patients from intervention and control groups \\
\hline
\end{tabular}

Nilasena 1995

Methods Cluster-randomized trial (blocked by site and level of training), unit of allocation: health professional 
Nilasena 1995 (Continued)

Participants
Patients: women: not clear; mean age: not clear; $n$ = 480 identified (164 analyzed)

Professionals: internal medicine residents, $n=35$ randomized out of 36

Setting: outpatient (2 clinics, USA)

Interventions

Active control: blank encounter form; educational meeting

Intervention: physician reminder; blank encounter form; ; educational meeting

Duration of intervention: 6 months

Outcomes Quality of care: overall compliance rate (primary)

Clinical area and targeted activity

Diabetes (multiple: test ordering, prescribing, general management, professional-patient communication)

Reminder

Description: The computer program outputs a printed paper health maintenance report for the patient's primary physician based on the currently available data for the patient. The report summarizes the patient's diabetes preventive-health status, and lists a schedule of upcoming or past due preventive-health activities for the patient. Clinical alerts about high-risk aspects of the patient's current profile are also presented. The report is placed at the front of the patient's chart.

Typology: patient-specific: YES; space for response: NO; explicit advice: YES; explanation: NOT CLEAR; reference: NO; at point-of-care: YES

Notes

\section{Risk of bias}

\begin{tabular}{|c|c|c|}
\hline Bias & Authors' judgement & Support for judgement \\
\hline $\begin{array}{l}\text { Random sequence genera- } \\
\text { tion (selection bias) }\end{array}$ & Unclear risk & "resident physicians were randomly assigned" \\
\hline $\begin{array}{l}\text { Allocation concealment } \\
\text { (selection bias) }\end{array}$ & Unclear risk & not described \\
\hline $\begin{array}{l}\text { Blinding of outcome as- } \\
\text { sessment (detection bias) } \\
\text { All outcomes }\end{array}$ & Unclear risk & manual chart review - no blinding procedure described \\
\hline $\begin{array}{l}\text { Incomplete outcome data } \\
\text { (attrition bias) } \\
\text { All outcomes }\end{array}$ & High risk & 480 patients identified, but 164 analyzed (34.2\%). No exclusion reasons. \\
\hline $\begin{array}{l}\text { Selective reporting (re- } \\
\text { porting bias) }\end{array}$ & Unclear risk & not clear \\
\hline Other bias & Unclear risk & not clear \\
\hline $\begin{array}{l}\text { Outcomes at baseline sim- } \\
\text { ilar? }\end{array}$ & High risk & $\begin{array}{l}\text { baseline compliance lower in control group (34.6\%) than intervention group } \\
(38.0 \%)\end{array}$ \\
\hline $\begin{array}{l}\text { Characteristics at baseline } \\
\text { similar? }\end{array}$ & Unclear risk & not reported \\
\hline $\begin{array}{l}\text { Adequate protection } \\
\text { against contamination? }\end{array}$ & Low risk & health professional randomized \\
\hline
\end{tabular}

Computer-generated reminders delivered on paper to healthcare professionals: effects on professional practice and healthcare outcomes 62 (Review)

Copyright @ 2017 The Cochrane Collaboration. Published by John Wiley \& Sons, Ltd. 
Oniki 2003

\begin{tabular}{|c|c|}
\hline Methods & Non-randomized trial, unit of allocation: patient \\
\hline \multirow[t]{3}{*}{ Participants } & Patients: women: not clear; mean age: not clear, $n=120$ \\
\hline & Professionals: nurses $(n=109)$ \\
\hline & Setting: inpatient ( 2 intensive care units in LDS Hospital, Department of Critical Care, Utah, USA) \\
\hline \multirow[t]{3}{*}{ Interventions } & Control: usual care \\
\hline & Intervention: physician reminder \\
\hline & Duration of intervention: 59 days ( 45 days in control group) \\
\hline Outcomes & $\begin{array}{l}\text { Quality of care: mean deficiencies per day per patient (patient's total number of deficiencies/number of } \\
\text { valid days in study) (primary) }\end{array}$ \\
\hline $\begin{array}{l}\text { Clinical area and targeted } \\
\text { activity }\end{array}$ & Intensive care (multiple: record keeping, general management) \\
\hline \multirow[t]{2}{*}{ Reminder } & $\begin{array}{l}\text { Description: The computer system stored any mid-day (13:00) reminders generated in a database. For } \\
\text { each patient in the study group, the program generated a reminder report which listed patient's room, } \\
\text { patient number/name, the date and any reminder (e.g. no Glasgow Coma Score between } 7: 00 \text { and } \\
\text { 13:00). Any reports containing reminders were delivered to charge nurse, who delivered them to the } \\
\text { bedside nurse. }\end{array}$ \\
\hline & $\begin{array}{l}\text { Typology: patient-specific: YES; space for response: NO; explicit advice: NO; explanation: NO; reference: } \\
\text { NO; at point-of-care: YES }\end{array}$ \\
\hline Notes & \\
\hline
\end{tabular}

\section{Risk of bias}

\begin{tabular}{|c|c|c|}
\hline Bias & Authors' judgement & Support for judgement \\
\hline $\begin{array}{l}\text { Random sequence genera- } \\
\text { tion (selection bias) }\end{array}$ & High risk & patients assigned according to ICU room to which they were admitted \\
\hline $\begin{array}{l}\text { Allocation concealment } \\
\text { (selection bias) }\end{array}$ & High risk & patients assigned according to ICU room to which they were admitted \\
\hline $\begin{array}{l}\text { Blinding of outcome as- } \\
\text { sessment (detection bias) } \\
\text { All outcomes }\end{array}$ & Low risk & outcome measure collected from computer system \\
\hline $\begin{array}{l}\text { Incomplete outcome data } \\
\text { (attrition bias) } \\
\text { All outcomes }\end{array}$ & Unclear risk & not clear \\
\hline $\begin{array}{l}\text { Selective reporting (re- } \\
\text { porting bias) }\end{array}$ & Unclear risk & not clear \\
\hline Other bias & Unclear risk & not clear \\
\hline $\begin{array}{l}\text { Outcomes at baseline sim- } \\
\text { ilar? }\end{array}$ & Unclear risk & not reported \\
\hline
\end{tabular}

Computer-generated reminders delivered on paper to healthcare professionals: effects on professional practice and healthcare outcomes 
Oniki 2003 (Continued)

Characteristics at baseline Unclear risk not reported
similar?

\begin{tabular}{|c|c|c|}
\hline $\begin{array}{l}\text { Adequate protection } \\
\text { against contamination? }\end{array}$ & High risk & 40 nurses cared for study and control patients \\
\hline
\end{tabular}

\section{Ornstein 1991}

\begin{tabular}{ll}
\hline Methods & Cluster-randomized trial, unit of allocation: practice, $n=4$ \\
\hline Participants & $\begin{array}{l}\text { Patients: }>18 \text { years old, due for prevention services; women: } 61 \% ; \text { mean age: } 40 ; n=7,397 \text { (3564 in } \\
\text { comparison 1; } 3833 \text { in comparison 2) } \\
\text { Professionals: } 49 \text { family physicians ( } 6 \text { faculty, } 1 \text { fellow, } 42 \text { residents) } \\
\text { Setting: outpatient (four practice groups in the Family Medicine Center at the Medical University of } \\
\text { South Carolina, USA) }\end{array}$ \\
\hline
\end{tabular}

Interventions Active control (comparison 1): educational meeting; audit and feedback

Intervention (comparison 1): physician reminder; educational meeting; audit and feedback

Active control (comparison 2): patient reminder; educational meeting; audit and feedback

Intervention (comparison 2): physician reminder; patient reminder; educational meeting; audit and feedback

Duration of intervention: 12 months

\section{Outcomes}

Quality of care: physician adherence rate to 5 preventive services: FOBT, mammography, tetanus vaccine, cholesterol, pap smear (median)

\section{Clinical area and targeted Preventive care/colorectal, breast, cervical cancer, tetanus vaccination and cholesterol prevention activity (multiple: test ordering, vaccination)}

Reminder Description: Reminder forms were generated by the computer system for each patient the night before
a scheduled appointment. The reminders were generated by scanning each patient record for deficient
preventive services based on the patient's age, sex, and last recorded time of the service. Forms were
printed on single sheets of paper and attached to the medical record by nursing personnel the morning
of the scheduled visit. The top half of the form listed identifying information and 0 to 5 deficient pre-
ventive services. It contained boxed for the physician to mark, indicating his or her action on each par-
ticular reminder. Actions included ordering the preventive service that day, scheduling the patient to
return for it another day, noting that it was not indicated for the patient, offering it to the patient but
having the patient refuse, or not discussing it. The bottom half of the reminder form listed any of the 5
preventive services appropriate for the patient's age and sex, and the date the item was last received.

Typology: patient-specific: YES; space for response: YES; explicit advice: YES; explanation: NO; reference: NO; at point-of-care: YES

\section{Notes}

\section{Risk of bias}

\begin{tabular}{lll}
\hline Bias & Authors' judgement & Support for judgement \\
\hline $\begin{array}{l}\text { Random sequence genera- } \\
\text { tion (selection bias) }\end{array}$ & Unclear risk & $\begin{array}{l}\text { "patients and their physicians were randomly assigned by practice group into } \\
\text { study groups" }\end{array}$ \\
\hline
\end{tabular}

Computer-generated reminders delivered on paper to healthcare professionals: effects on professional practice and healthcare outcomes (Review)

Copyright (c) 2017 The Cochrane Collaboration. Published by John Wiley \& Sons, Ltd. 
Ornstein 1991 (Continued)

\begin{tabular}{lll}
$\begin{array}{l}\text { Allocation concealment } \\
\text { (selection bias) }\end{array}$ & Unclear risk & not described \\
\hline $\begin{array}{l}\text { Blinding of outcome as- } \\
\text { sessment (detection bias) }\end{array}$ & Low risk & "[outcome] assessed through computerized medical records" \\
Alloutcom & &
\end{tabular}

All outcomes

Incomplete outcome data Unclear risk not clear
(attrition bias)
All outcomes

\begin{tabular}{lll}
\hline $\begin{array}{l}\text { Selective reporting (re- } \\
\text { porting bias) }\end{array}$ & Unclear risk & not clear \\
\hline Other bias & Unclear risk & not clear \\
\hline $\begin{array}{l}\text { Outcomes at baseline sim- } \\
\text { ilar? }\end{array}$ & High risk & adherence rate at baseline differ according to study groups \\
\hline $\begin{array}{l}\text { Characteristics at baseline } \\
\text { similar? }\end{array}$ & High risk & $\begin{array}{l}\text { "statistically significant differences between study groups were present for } \\
\text { race, insurance coverage, and visit frequency" }\end{array}$ \\
\hline $\begin{array}{l}\text { Adequate protection } \\
\text { against contamination? }\end{array}$ & Low risk & physicians randomized \\
\hline
\end{tabular}

Rosser 1991

\begin{tabular}{|c|c|}
\hline Methods & Cluster-randomized trial, unit of allocation: family, $n=4450$ families randomized \\
\hline \multirow[t]{4}{*}{ Participants } & $\begin{array}{l}\text { Patients: } 15 \text { years old or more; percentage of women: not clear; mean age: not clear; } 1403 \text { patients } \\
\text { (1056 families) randomized to usual care and } 1471 \text { patients ( } 1122 \text { families) randomized to included } \\
\text { study arm }\end{array}$ \\
\hline & $\begin{array}{l}\text { Flu arm: } 822 \text { families randomized, } 939 \text { patients; blood pressure arm: } 4247 \text { families randomized, } 5744 \\
\text { patients; Pap arm: } 1406 \text { women randomized; Tetanus arm: } 4247 \text { families randomized, } 5589 \text { patients }\end{array}$ \\
\hline & Professionals: staff physicians, residents, and nurses, $\mathrm{n}=$ not clear \\
\hline & Setting: outpatient (four practices, University of Ottawa Family Medicine Center, Canada) \\
\hline
\end{tabular}

\begin{tabular}{ll} 
Interventions & Control: usual care \\
& Intervention: physician reminder \\
& Duration of intervention: 12 months (69 days for flu arm) \\
\hline Outcomes & $\begin{array}{l}\text { Quality of care: rate of eligible patients for whom the recommended procedure was performed (prima- } \\
\text { ry); rate of eligible patients with: influenza vaccination, blood pressure reading, pap test, tetanus vacci- } \\
\text { nation }\end{array}$
\end{tabular}
Clinical area and targeted Preventive care/influenza vaccination, blood pressure, smoking status, pap test, tetanus (multiple: test activity ordering, vaccination)

Reminder Description: Computer-generated reminders were included on the routinely printed encounter form
before any visit to the office to remind the physician of outstanding preventive procedures. Until the
procedure or reading was recorded, the computer continued to generate reminders on subsequent
visits. Influenza vaccination reminder: for patients who had not already been vaccinated, the mes-

Computer-generated reminders delivered on paper to healthcare professionals: effects on professional practice and healthcare outcomes 
Rosser 1991 (Continued)

sage stated "Patient 65 or older: check flu immunization". Blood pressure reminder: When the patient booked an appointment, the computer printed a reminder advising the doctor to "Check blood pressure". Pap reminder: for women who had not been screened during previous year, the computer printed a message to the physician to recommend cervical screening. Tetanus vaccination reminder: "ask patient about tetanus vaccination" was included on the routinely printed encounter form.

Typology: patient-specific: YES; space for response: NO; explicit advice: YES; explanation: NO; reference: NO; at point-of-care: YES

Additional study interventions excluded from analyses: a) patient phone reminder, b) patient letter re-
minder

\section{Risk of bias}

\begin{tabular}{|c|c|c|}
\hline Bias & Authors' judgement & Support for judgement \\
\hline $\begin{array}{l}\text { Random sequence genera- } \\
\text { tion (selection bias) }\end{array}$ & Low risk & "with the use of a standard randomization computer program" \\
\hline $\begin{array}{l}\text { Allocation concealment } \\
\text { (selection bias) }\end{array}$ & Unclear risk & not described \\
\hline $\begin{array}{l}\text { Blinding of outcome as- } \\
\text { sessment (detection bias) } \\
\text { All outcomes }\end{array}$ & Unclear risk & $\begin{array}{l}\text { Influenza vaccination recorded in the computer, but data completed by phone } \\
\text { calls which are not described as blinded }\end{array}$ \\
\hline $\begin{array}{l}\text { Incomplete outcome data } \\
\text { (attrition bias) } \\
\text { All outcomes }\end{array}$ & Low risk & $\begin{array}{l}\text { possible that patients had undergone preventive measures somewhere else, } \\
\text { but similar situation across groups }\end{array}$ \\
\hline $\begin{array}{l}\text { Selective reporting (re- } \\
\text { porting bias) }\end{array}$ & Unclear risk & not clear \\
\hline Other bias & Unclear risk & not clear \\
\hline $\begin{array}{l}\text { Outcomes at baseline sim- } \\
\text { ilar? }\end{array}$ & Unclear risk & not reported \\
\hline $\begin{array}{l}\text { Characteristics at baseline } \\
\text { similar? }\end{array}$ & Low risk & $\begin{array}{l}\text { no significant difference for age and gender (family size was different before } \\
\text { exclusion of practices) }\end{array}$ \\
\hline $\begin{array}{l}\text { Adequate protection } \\
\text { against contamination? }\end{array}$ & Unclear risk & $\begin{array}{l}\text { families (patients) randomized; physicians likely saw both study and control } \\
\text { patients }\end{array}$ \\
\hline
\end{tabular}

\section{Rossi 1997}

\begin{tabular}{ll}
\hline Methods & Cluster-randomized trial, unit of allocation: health professional \\
\hline Participants & Patients: men: $96 \%$, mean age: $68, n=719$ patients \\
& Professionals: physicians $(n=15)$, residents/fellows $(n=44)$ and nurse practitioners $(n=12)$ \\
& Setting: outpatient (General internal medicine clinic of the VA Pounget Sound Health Care System, USA) \\
\hline Interventions & Control: usual care \\
& Intervention: physician reminder
\end{tabular}

Computer-generated reminders delivered on paper to healthcare professionals: effects on professional practice and healthcare outcomes 
Rossi 1997 (Continued)

Duration of intervention: 6 months

Outcomes Quality of care: prescription change rate (primary)

Patient outcomes: mean blood pressure

Resource use: mean clinic visits per patient, mean ED visits per patient, mean creatinine tests per patient, mean total cholesterol tests per patient

\section{Clinical area and targeted Hypertension (prescribing)}

activity

Reminder

Description: An automated computer query system identified eligible patients and their providers. For each clinic visit, for each eligible patient, providers had a 1-page guideline reminder placed in the patient chart by the clinic pharmacist, attached to the medication refill forms that are given to providers at every patient visit. The reminder highlighted the prescription and offered alternative drugs and doses. For continued medication use, the reminder also asked provider to designate 1 of 4 indications.

Typology: patient-specific: YES; space for response: YES; explicit advice: YES; explanation: YES; reference: YES; at point-of-care: YES

\section{Notes}

\section{Risk of bias}

\begin{tabular}{|c|c|c|}
\hline Bias & Authors' judgement & Support for judgement \\
\hline $\begin{array}{l}\text { Random sequence genera- } \\
\text { tion (selection bias) }\end{array}$ & Low risk & $\begin{array}{l}\text { "A random number generator was used to randomize providers, stratified to } \\
\text { whether they were staff physicians, nurse practitioners, or residents or fel- } \\
\text { lows". }\end{array}$ \\
\hline $\begin{array}{l}\text { Allocation concealment } \\
\text { (selection bias) }\end{array}$ & Low risk & $\begin{array}{l}\text { randomization at the physician level; providers were assigned numeric codes } \\
\text { and study investigators were blinded to the coding identifiers }\end{array}$ \\
\hline $\begin{array}{l}\text { Blinding of outcome as- } \\
\text { sessment (detection bias) } \\
\text { All outcomes }\end{array}$ & Low risk & outcome data from computer database \\
\hline $\begin{array}{l}\text { Incomplete outcome data } \\
\text { (attrition bias) } \\
\text { All outcomes }\end{array}$ & Unclear risk & not clear \\
\hline $\begin{array}{l}\text { Selective reporting (re- } \\
\text { porting bias) }\end{array}$ & Unclear risk & not clear \\
\hline Other bias & Unclear risk & not clear \\
\hline $\begin{array}{l}\text { Outcomes at baseline sim- } \\
\text { ilar? }\end{array}$ & Unclear risk & not reported \\
\hline $\begin{array}{l}\text { Characteristics at baseline } \\
\text { similar? }\end{array}$ & High risk & $\begin{array}{l}\text { provider characteristics (type, gender, number patients, number patient vis- } \\
\text { its) were not statistically different; patient characteristics (age, race, gender, } \\
\text { weight, blood pressure) were not statistically different, but mean prescriptions } \\
\text { per patient and percentage on ß-blockers and ACE inhibitors were different }\end{array}$ \\
\hline $\begin{array}{l}\text { Adequate protection } \\
\text { against contamination? }\end{array}$ & Low risk & physicians randomized \\
\hline
\end{tabular}


Thomas 1983

\begin{tabular}{ll}
\hline Methods & Randomized trial, unit of allocation: patient \\
\hline Participants & Patients: diabetic patients; percentage of women: not clear, mean age: not clear; $\mathrm{n}=185$ (133 analyzed) \\
& Professionals: physicians, $\mathrm{n}=$ not clear \\
& Setting: outpatient (University of Texas Medical School Ambulatory Clinic, USA)
\end{tabular}

\begin{tabular}{ll}
\hline Interventions & Control: usual care \\
& Intervention: physician reminder \\
& Duration of intervention: 12 months (not finished) \\
\hline Outcomes & Quality of care: compliance rate (primary) \\
& $\begin{array}{l}\text { Resource use/cost: percentage of patients hospitalized, mean days of hospitalization, mean number of } \\
\text { patient visits, mean costs per patient }\end{array}$
\end{tabular}

Clinical area and targeted Diabetes (multiple: not specified) activity

Rescription: An automated chart audit is obtained for each patient scheduled to attend the clinic,
based on protocol-driven algorithms, and prints a report for the physician. $80 \%$ of suggestions are rec-
ommendations concerning general medicine and preventive care, and $20 \%$ are for specific speciality
problems.
Typology: patient-specific: YES; space for response: NO; explicit advice: YES; explanation: NOT CLEAR;
reference: NOT CLEAR; at point-of-care: YES

\section{Notes}

\section{Risk of bias}

\begin{tabular}{lll}
\hline Bias & Authors' judgement & Support for judgement \\
\hline $\begin{array}{l}\text { Random sequence genera- } \\
\text { tion (selection bias) }\end{array}$ & Unclear risk & "Patients were assigned through the use of stratified random sample" \\
\hline $\begin{array}{l}\text { Allocation concealment } \\
\text { (selection bias) }\end{array}$ & Unclear risk & not described \\
\hline $\begin{array}{l}\text { Blinding of outcome as- } \\
\text { sessment (detection bias) } \\
\text { All outcomes }\end{array}$ & Unclear risk & $\begin{array}{l}\text { "a medical research assistant interviewed each patient for every visit during } \\
\text { the study; all study data were then coded and entered into the automated } \\
\text { medical record system" }\end{array}$ \\
\hline $\begin{array}{l}\text { Incomplete outcome data } \\
\text { (attrition bias) }\end{array}$ & High risk & $\begin{array}{l}\text { 305 patients entered study; 52 dropped out; 133 with first 12 mo data (43.6\%) } \\
\text { All outcomes }\end{array}$ \\
\hline $\begin{array}{l}\text { Selective reporting (re- } \\
\text { porting bias) }\end{array}$ & Unclear risk & not clear \\
\hline $\begin{array}{l}\text { Other bias } \\
\text { Outcomes at baseline sim- }\end{array}$ & Unclear risk & not reported \\
\hline \begin{tabular}{l} 
ilar? \\
\hline
\end{tabular}
\end{tabular}

Computer-generated reminders delivered on paper to healthcare professionals: effects on professional practice and healthcare outcomes 
Thomas 1983 (Continued)

\begin{tabular}{lll}
$\begin{array}{l}\text { Characteristics at baseline } \\
\text { similar? }\end{array}$ & Unclear risk & not reported \\
\hline $\begin{array}{l}\text { Adequate protection } \\
\text { against contamination? }\end{array}$ & High risk & patients randomized \\
\hline
\end{tabular}

Tierney 1986

\begin{tabular}{ll}
\hline Methods & Cluster-randomized trial, unit of allocation: clinic session $(\mathrm{n}=32)$ \\
\hline Participants & Patients: percentage women: not clear, mean age: not clear; $\mathrm{n}=6045$ \\
& Professionals: faculty, interns and residents, $\mathrm{n}=135$ \\
& Setting: outpatient (general medicine clinic of Wishard Memorial Hospital, Indianapolis, USA) \\
\hline Interventions & Control (comparison 1): usual care \\
& Intervention (comparison 1): physician reminder \\
& Active control (comparison 2): feedback (delayed reminder) \\
Intervention (comparison 2): physician reminder; feedback (delayed reminder) \\
Duration of intervention: 7 months \\
\hline $\begin{array}{l}\text { Quality of care: physician compliance with 13 protocols: FOBT, pneumococcal vaccination, antacids, TB } \\
\text { skin testing, beta-blockers, nitrates, anti-depressants, calcium supplements, pap smear, mammogra- } \\
\text { phy, metronidazole, digitalis, salicylates (median) }\end{array}$ \\
\hline
\end{tabular}

\section{Clinical area and targeted Preventive care (multiple: test ordering, vaccination, prescribing)} activity

\begin{tabular}{|c|c|c|}
\hline Reminder & \multirow{2}{*}{\multicolumn{2}{|c|}{$\begin{array}{l}\text { Description: The reminders were generated the night before scheduled appointments and were placed } \\
\text { in patients' clinical charts. Each reminder identified the patient and listed the suggested preventive } \\
\text { care along with data from the computer record that made the patient eligible for the action, along with } \\
\text { supporting references (same system as McDonald 1984). } \\
\text { Typology: Patient-specific: YES; space for response: NO; explicit advice: YES; explanation: NO; refer- } \\
\text { ence: YES; at point-of-care: YES }\end{array}$}} \\
\hline & & \\
\hline Notes & \multicolumn{2}{|c|}{ Data extracted from graphics. Author not contacted as publication date $>10$ years. } \\
\hline \multicolumn{3}{|l|}{ Risk of bias } \\
\hline Bias & Authors' judgement & Support for judgement \\
\hline $\begin{array}{l}\text { Random sequence genera- } \\
\text { tion (selection bias) }\end{array}$ & Unclear risk & "we randomized house staff by their clinic session" \\
\hline $\begin{array}{l}\text { Allocation concealment } \\
\text { (selection bias) }\end{array}$ & Unclear risk & not described \\
\hline $\begin{array}{l}\text { Blinding of outcome as- } \\
\text { sessment (detection bias) } \\
\text { All outcomes }\end{array}$ & Low risk & computerized data \\
\hline
\end{tabular}


Tierney 1986 (Continued)

Incomplete outcome data Unclear risk not clear
(attrition bias)

All outcomes

\begin{tabular}{lll}
\hline $\begin{array}{l}\text { Selective reporting (re- } \\
\text { porting bias) }\end{array}$ & Unclear risk & not clear \\
\hline Other bias & Low risk & not clear \\
\hline $\begin{array}{lll}\text { Outcomes at baseline sim- } \\
\text { ilar? }\end{array}$ & Unclear risk & not reported \\
\hline $\begin{array}{l}\text { Characteristics at baseline } \\
\text { similar? }\end{array}$ & Unclear risk & not reported \\
\hline $\begin{array}{l}\text { Adequate protection } \\
\text { against contamination? }\end{array}$ & Low risk & allocation by clinic session \\
\hline
\end{tabular}

\section{Turner 1989}

\begin{tabular}{|c|c|}
\hline Methods & Cluster non-randomized trial, unit of allocation: clinic team $(n=5)$ \\
\hline \multirow[t]{3}{*}{ Participants } & $\begin{array}{l}\text { Patients: with multiple chronic diseases, } \geq 20 \text { yr, women: } 74 \% \text {, mean age: } 60 ; n=253 \text { ( } n=150 \text { in includ- } \\
\text { ed study arms) }\end{array}$ \\
\hline & Professionals: junior and senior residents $(n=39)$ in 5 clinic teams $(n=25$ in included study arms) \\
\hline & Setting: outpatient (general medicine clinic, USA) \\
\hline \multirow[t]{3}{*}{ Interventions } & $\begin{array}{l}\text { Active control: patient-mediated intervention (questionnaire given to physician); distribution of educa- } \\
\text { tional material to patient }\end{array}$ \\
\hline & $\begin{array}{l}\text { Intervention: physician reminder; patient-mediated intervention (questionnaire given to physician); } \\
\text { distribution of educational material to patient }\end{array}$ \\
\hline & Duration of intervention: 6 months \\
\hline
\end{tabular}

\section{Outcomes}

Quality of care: adherence rates to recommendations: FOBT, rectal exam, mammography, pap smear, breast exam (median)

\section{Clinical area and targeted Preventive care (test ordering) activity}

Description: The computer record/reminder system used age- and sex-standardized criteria for preventive care to generate patient-specific reminder that was printed at the bottom of each patient's visit record sheet. Physicians were instructed to write in the date on which each listed service was last completed $(\mathrm{C})$ or requested (R). On subsequent visits, the computer printed the updated information on the visit record; an asterisk in the "due " column indicated that it was time to repeat the service.

Typology: Patient-specific: YES; space for response: YES; explicit advice: YES; explanation: NO; reference: NO; at point-of-care: YES

\section{Risk of bias}


Turner 1989 (Continued)

\begin{tabular}{|c|c|c|}
\hline Bias & Authors' judgement & Support for judgement \\
\hline $\begin{array}{l}\text { Random sequence genera- } \\
\text { tion (selection bias) }\end{array}$ & High risk & allocation by day \\
\hline $\begin{array}{l}\text { Allocation concealment } \\
\text { (selection bias) }\end{array}$ & High risk & allocation by day \\
\hline $\begin{array}{l}\text { Blinding of outcome as- } \\
\text { sessment (detection bias) } \\
\text { All outcomes }\end{array}$ & High risk & $\begin{array}{l}\text { "chart abstractors were not blind to the clinic groups of the patients in the au- } \\
\text { dit" }\end{array}$ \\
\hline $\begin{array}{l}\text { Incomplete outcome data } \\
\text { (attrition bias) } \\
\text { All outcomes }\end{array}$ & Unclear risk & not clear \\
\hline $\begin{array}{l}\text { Selective reporting (re- } \\
\text { porting bias) }\end{array}$ & High risk & $\begin{array}{l}\text { tetanus vaccination rate not shown, as performance rate remained at less than } \\
10 \% \text { despite the interventions }\end{array}$ \\
\hline Other bias & Unclear risk & not clear \\
\hline $\begin{array}{l}\text { Outcomes at baseline sim- } \\
\text { ilar? }\end{array}$ & High risk & $\begin{array}{l}\text { "extremely poor performance of mammography by the residents in the com- } \\
\text { puter/questionnaire group" }\end{array}$ \\
\hline $\begin{array}{l}\text { Characteristics at baseline } \\
\text { similar? }\end{array}$ & Low risk & "no significant differences were found among groups" \\
\hline $\begin{array}{l}\text { Adequate protection } \\
\text { against contamination? }\end{array}$ & Low risk & clinic teams allocated, on different days \\
\hline
\end{tabular}

Were 2013

\begin{tabular}{|c|c|}
\hline Methods & Randomized trial, unit of allocation: patient \\
\hline \multirow[t]{3}{*}{ Participants } & Patients: women: $49.3 \%$, mean age: $7, \mathrm{n}=1619$ randomized (1611 analyzed) \\
\hline & Professionals: clinical officer, physician, nurse $(n=30)$ \\
\hline & Setting: outpatient (pediatric HIV clinic, Kenya) \\
\hline \multirow[t]{3}{*}{ Interventions } & Control: usual care \\
\hline & Intervention: physician reminder \\
\hline & Duration of intervention: 5 months \\
\hline Outcomes & $\begin{array}{l}\text { Quality of care: completion of overdue clinical tasks (primary); mean time (days) from when a patient } \\
\text { had an overdue clinical task to the completion of the task }\end{array}$ \\
\hline $\begin{array}{l}\text { Clinical area and targeted } \\
\text { activity }\end{array}$ & HIV care (multiple: prescription, test ordering, referral) \\
\hline Reminder & $\begin{array}{l}\text { The patient-specific clinical summary, tailored for pediatric care, displayed selected information from } \\
\text { the patient's EHR to provide a quick reference to the most relevant data needed by clinicians. The mod- } \\
\text { ule also contained CDSS functionality that appended patient- specific care reminders (overdue tests } \\
\text { and treatments) to the bottom of the clinical summary. All summaries were attached to the relevant } \\
\text { patients' paper charts for clinicians to review during a patient's clinic visit. Clinicians were asked to }\end{array}$ \\
\hline
\end{tabular}

Computer-generated reminders delivered on paper to healthcare professionals: effects on professional practice and healthcare outcomes 
Were 2013 (Continued)

document their response to each reminder. No more than 5 reminders were displayed for each patient per visit.

Typology: patient-specific: YES; space for response: YES; explicit advice: YES; explanation: YES; reference: YES; at point-of-care: YES

\author{
Notes
}

\title{
Risk of bias
}

\begin{tabular}{|c|c|c|}
\hline Bias & Authors' judgement & Support for judgement \\
\hline $\begin{array}{l}\text { Random sequence genera- } \\
\text { tion (selection bias) }\end{array}$ & Low risk & $\begin{array}{l}\text { "All patients, both HIV-exposed and HIV-infected, previously enrolled at the } \\
\text { study site were randomly assigned to either the intervention or control group } \\
\text { in a 1:1 ratio by using a 4-block randomization scheme." }\end{array}$ \\
\hline $\begin{array}{l}\text { Allocation concealment } \\
\text { (selection bias) }\end{array}$ & Unclear risk & method of concealment not described \\
\hline $\begin{array}{l}\text { Blinding of outcome as- } \\
\text { sessment (detection bias) } \\
\text { All outcomes }\end{array}$ & High risk & Authors don't mention blinding of outcome assessors. \\
\hline $\begin{array}{l}\text { Incomplete outcome data } \\
\text { (attrition bias) } \\
\text { All outcomes }\end{array}$ & Unclear risk & $\begin{array}{l}8 \text { patients were excluded from the analyses because they were seen by a clini- } \\
\text { cian involved in the study. It is unclear if all the charts have been reviewed and } \\
\text { if no data is missing. }\end{array}$ \\
\hline $\begin{array}{l}\text { Selective reporting (re- } \\
\text { porting bias) }\end{array}$ & Low risk & $\begin{array}{l}\text { Primary outcome stated in the trial registry matches the primary outcome in } \\
\text { the published results. }\end{array}$ \\
\hline Other bias & Unclear risk & not clear. \\
\hline $\begin{array}{l}\text { Outcomes at baseline sim- } \\
\text { ilar? }\end{array}$ & Unclear risk & no baseline outcome measures \\
\hline $\begin{array}{l}\text { Characteristics at baseline } \\
\text { similar? }\end{array}$ & Low risk & $\begin{array}{l}\text { "There were no statistically significant differences in the demographic charac- } \\
\text { teristics between the control and intervention groups." }\end{array}$ \\
\hline $\begin{array}{l}\text { Adequate protection } \\
\text { against contamination? }\end{array}$ & High risk & $\begin{array}{l}\text { Clinicians received reminders for some patients but not others. "We ran- } \\
\text { domized by patient in- stead of by clinician, because patients typically saw } \\
\text { whichever clinician was first available at the time of their visit, and it was not } \\
\text { possible to tell in advance which patient a clinician would see. We understood } \\
\text { that this could sensitize clinicians to order the indicated care for control pa- } \\
\text { tients, which might bias our study against finding a significant effect for the re- } \\
\text { minders." }\end{array}$ \\
\hline
\end{tabular}

White 1984

\begin{tabular}{ll}
\hline Methods & Randomized trial, unit of allocation: patient \\
\hline Participants & Patients: women: $50 \%$, mean age: $69, \mathrm{n}=396$ \\
& Professionals: physicians, $\mathrm{n}=$ not clear \\
& Setting: inpatient (Hospital, Utah, USA) \\
\hline Interventions & Control: usual care
\end{tabular}

Computer-generated reminders delivered on paper to healthcare professionals: effects on professional practice and healthcare outcomes 
White 1984 (Continued)

Intervention: physician reminder

Duration of intervention: 3 months

\begin{tabular}{|c|c|}
\hline Outcomes & Quality of care: compliance rate (primary) \\
\hline $\begin{array}{l}\text { Clinical area and targeted } \\
\text { activity }\end{array}$ & Digoxin intoxication (prescribing) \\
\hline Reminder & $\begin{array}{l}\text { Description: Each night, the computer program activates the alert modules for all patients in the hos- } \\
\text { pital. Alert message are formatted into a "digoxin alert report" that is sent out to a line printer in the } \\
\text { nursing division nearest the patient. This report is placed in the patient chart by nursing personnel. }\end{array}$ \\
\hline & $\begin{array}{l}\text { Typology: Patient-specific: YES; space for response: NO, explicit advice: YES; explanation: YES; refer- } \\
\text { ence: NO; at point-of-care: YES }\end{array}$ \\
\hline
\end{tabular}

\section{Notes}

\section{Risk of bias}

\begin{tabular}{|c|c|c|}
\hline Bias & Authors' judgement & Support for judgement \\
\hline $\begin{array}{l}\text { Random sequence genera- } \\
\text { tion (selection bias) }\end{array}$ & Low risk & $\begin{array}{l}\text { "a random number generator was used to assign patients to an alert or } \\
\text { nonalert group" }\end{array}$ \\
\hline $\begin{array}{l}\text { Allocation concealment } \\
\text { (selection bias) }\end{array}$ & Unclear risk & not described \\
\hline $\begin{array}{l}\text { Blinding of outcome as- } \\
\text { sessment (detection bias) } \\
\text { All outcomes }\end{array}$ & Low risk & $\begin{array}{l}\text { "a blinded medical record review was carried out in accordance with a proto- } \\
\text { col aimed at identifying physician actions with possible relation to the digoxin } \\
\text { alerts" }\end{array}$ \\
\hline $\begin{array}{l}\text { Incomplete outcome data } \\
\text { (attrition bias) } \\
\text { All outcomes }\end{array}$ & Unclear risk & not clear \\
\hline $\begin{array}{l}\text { Selective reporting (re- } \\
\text { porting bias) }\end{array}$ & Unclear risk & not clear \\
\hline Other bias & Unclear risk & not clear \\
\hline $\begin{array}{l}\text { Outcomes at baseline sim- } \\
\text { ilar? }\end{array}$ & Unclear risk & not reported \\
\hline $\begin{array}{l}\text { Characteristics at baseline } \\
\text { similar? }\end{array}$ & Low risk & $\begin{array}{l}\text { "there was no statistically significant difference between groups for sex, age, } \\
\text { and medical/surgical service" }\end{array}$ \\
\hline $\begin{array}{l}\text { Adequate protection } \\
\text { against contamination? }\end{array}$ & High risk & patients randomized \\
\hline
\end{tabular}

\section{Ziemer 2006}

\begin{tabular}{ll}
\hline Methods & Cluster-randomized trial $(2 \times 2$ factorial design), unit of allocation: half-day session $(n=40)$ \\
\hline Participants & Patients: women: $67 \%$; mean age: $59 ; 4,138$ patients $(n=2026$ in comparison $1 ; n=2112$ in comparison
\end{tabular}


Professionals: 345 providers (faculty, residents) (approx. 8 per session)

Setting: outpatient ( 2 clinics with 20 half-day sessions each in Atlanta, USA)

Active control (comparison 1): educational meetings; distribution of educational material to physicians
Intervention (comparison 1): physician reminder; educational meetings; distribution of educational
material to physicians
Active control (comparison 2): educational meetings; distribution of educational material to physi-
cians; audit and feedback
Intervention (comparison 2): physician reminder ;educational meetings; distribution of educational
material to physicians; audit and feedback
Duration of intervention: 3 years

Quality of care: providers who did enough (at 36 months)
Patient outcomes: glycated hemoglobin level (primary); systolic blood pressure; LDL cholesterol; pa-
tients with glycated hemoglobin $<7 \%$; patients with systolic blood pressure $<130 \mathrm{mmHg}$ (no percent-
age data); patients with LDL cholesterol $<100 \mathrm{mg} / \mathrm{dL}$ (no percentage data)

\section{Clinical area and targeted Diabetes (general management)} activity

Description: The reminder includes a flow sheet showing clinically relevant parameters during the
present visit and several previous visits, together with specific recommendations for management. The
reminders document the course of critical values, provide notice when evaluations are due, include in-
dividualized recommendations for modifications in therapy. The patient-specific reminder is printed
out and attached to the front of the chart each time a patient with diabetes presents for a visit; a specif-
ic reminder sheet will be generated for each diabetic patient to be seen each week.
Typology: Patient-specific: YES; space for response: NO; explicit advice: YES; explanation: NO; refer-
ence: NO; at point-of-care: YES

Notes Process data provided by authors.

\section{Risk of bias}

\begin{tabular}{lll}
\hline Bias & Authors' judgement & Support for judgement \\
\hline $\begin{array}{l}\text { Random sequence genera- } \\
\text { tion (selection bias) }\end{array}$ & Unclear risk & $\begin{array}{l}\text { half-day medical clinic sessions randomized; randomization not explicitly de- } \\
\text { scribed }\end{array}$ \\
\hline $\begin{array}{l}\text { Allocation concealment } \\
\text { (selection bias) }\end{array}$ & Unclear risk & not described \\
\hline $\begin{array}{l}\text { Blinding of outcome as- } \\
\text { sessment (detection bias) } \\
\text { All outcomes }\end{array}$ & Unclear risk & not clear \\
\hline $\begin{array}{l}\text { Incomplete outcome data } \\
\text { (attrition bias) }\end{array}$ & Unclear risk & not clear \\
$\begin{array}{l}\text { All outcomes } \\
\begin{array}{l}\text { Selective reporting (re- } \\
\text { porting bias) }\end{array}\end{array}$ & Unclear risk & $\begin{array}{l}\text { In published design paper, outcomes to be reported: level of glycated hemo- } \\
\text { globin, blood pressure and lipid levels. Intensification of therapy, eye exam } \\
\text { and foot exam: only results on intensification reported. }\end{array}$ \\
\hline
\end{tabular}


Ziemer 2006 (Continued)

\begin{tabular}{lll} 
Other bias & Unclear risk & not clear \\
\hline $\begin{array}{l}\text { Outcomes at baseline sim- } \\
\text { ilar? }\end{array}$ & Low risk & $\begin{array}{l}\text { there were no differences in compliance rates among the different interven- } \\
\text { tion arms at baseline (data sent by author) }\end{array}$ \\
\hline $\begin{array}{l}\text { Characteristics at baseline } \\
\text { similar? }\end{array}$ & Low risk & $\begin{array}{l}\text { there were no significant differences among the patients assigned to residents } \\
\text { in the different intervention arms }\end{array}$ \\
\hline $\begin{array}{l}\text { Adequate protection } \\
\text { against contamination? }\end{array}$ & Low risk & half-day medical clinic sessions randomized \\
\hline
\end{tabular}

ACE: angiotensin converting enzyme, ARB: angiotensin receptor blocker, ED: emergency department, FOBT: fecal occult blood test, GEE: generalized estimating equation, HIV: human immunodeficiency virus, HMO: health maintenance organization, ICU: intensive care unit, LDL: low-density lipoprotein, TB: tuberculosis, VA: Veterans Affairs

Characteristics of excluded studies [ordered by study ID]

\begin{tabular}{|c|c|}
\hline Study & Reason for exclusion \\
\hline Adelman 2013 & Reminders delivered onscreen \\
\hline Alfadda 2011 & Ineligible comparison group or inappropriate control (assistant-initiated reminder) \\
\hline Anabtawi 2013 & Reminders delivered onscreen \\
\hline Anchala 2012 & Ineligible comparison group or inappropriate control \\
\hline Barkun 2013 & Ineligible comparison or inappropriate control \\
\hline Barnes 2014 & Ineligible comparison or inappropriate control \\
\hline Beeckman 2013 & Ineligible comparison or inappropriate control \\
\hline Beeler 2014 & Reminders delivered onscreen \\
\hline Belland 2014 & Reminders delivered onscreen \\
\hline Beste 2015 & Reminders delivered onscreen \\
\hline Braun 2013 & Ineligible comparison or inappropriate control \\
\hline Campbell 2014 & Ineligible comparison or inappropriate control \\
\hline Carroll 2013 & Ineligible comparison or inappropriate control \\
\hline Chen 2013 & Not computer-generated \\
\hline Dexheimer 2013 & Ineligible comparison or inappropriate control \\
\hline Divinskiy 2015 & Ineligible comparison or inappropriate control \\
\hline dos Santos 2014 & Reminders delivered onscreen \\
\hline Erlingsdottir 2015 & Not computer-generated \\
\hline
\end{tabular}




\begin{tabular}{|c|c|}
\hline Study & Reason for exclusion \\
\hline Federman 2014 & Reminders delivered onscreen \\
\hline Gifford 2013 & Not a reminder \\
\hline Goldstein 2014 & Reminders delivered onscreen \\
\hline Green 2014 & Ineligible comparison or inappropriate control \\
\hline Gupta 2014 & Reminders delivered onscreen \\
\hline Hendrix 2015 & Ineligible comparison or inappropriate control \\
\hline Hye 2014 & Reminders delivered onscreen \\
\hline Jansink 2013 & Ineligible comparison or inappropriate control \\
\hline Kennedy 2012 & Ineligible comparison or inappropriate control \\
\hline Kousgaard 2013 & Reminders delivered onscreen \\
\hline Lai 2015 & Reminders delivered onscreen \\
\hline Levy 2013 & Mixed reminder \\
\hline Lusignan 2013 & Ineligible comparison or inappropriate control \\
\hline Lynn 2013 & Ineligible comparison or inappropriate control \\
\hline Majumdar 2012 & Mixed reminder \\
\hline Maximov 2013 & Ineligible comparison or inappropriate control \\
\hline McEvoy 2014 & Not a reminder \\
\hline McNulty 2014 & Ineligible comparison or inappropriate control \\
\hline Melo 2013 & Ineligible comparison or inappropriate control \\
\hline Neal 2012 & Not original study \\
\hline Nguyen 2014 & Reminders delivered onscreen \\
\hline O'Reilly 2012 & Not original study \\
\hline Persell 2016 & Reminders delivered onscreen \\
\hline Piazza 2013 & Not computer-generated \\
\hline Roy 2016 & Not computer-generated \\
\hline Schwalm 2015 & Ineligible comparison or inappropriate control \\
\hline Siersma 2015 & Ineligible comparison or inappropriate control \\
\hline Stockwell 2015 & Reminders delivered onscreen \\
\hline
\end{tabular}

Computer-generated reminders delivered on paper to healthcare professionals: effects on professional practice and healthcare outcomes 


\begin{tabular}{ll}
\hline Study & Reason for exclusion \\
\hline Szilagyi 2015 & Reminders delivered onscreen \\
\hline Tartaglia 2013 & Ineligible comparison or inappropriate control \\
\hline Tedja 2014 & Mixed reminder \\
\hline Teoh 2012 & Not computer-generated \\
\hline Weiss 2013 & Reminders delivered onscreen \\
\hline Were 2011 & Ineligible comparison or inappropriate control \\
\hline
\end{tabular}

\section{ADDITIONAL TABLES}

Table 1. Improvement rates of quality of care, by study

\begin{tabular}{|c|c|c|c|c|}
\hline Study ID & Primary outcome & Other outcomes (n) & $\begin{array}{l}\text { Absolute im- } \\
\text { provement - us- } \\
\text { ing primary out- } \\
\text { come }\end{array}$ & $\begin{array}{l}\text { Median ab- } \\
\text { solute improve- } \\
\text { ment - using } \\
\text { other outcomes } \\
\text { (interquartile } \\
\text { range) }\end{array}$ \\
\hline Barnett 1983 & & $\begin{array}{l}\text { percentage of eligible patients with: blood } \\
\text { pressure values on record, follow-up (2) }\end{array}$ & & $\begin{array}{l}38.8 \%(18.4 \% \text { to } \\
59.1 \%)\end{array}$ \\
\hline Becker 1989 & $\begin{array}{l}\text { overall compliance } \\
\text { rate with preventive } \\
\text { care recommenda- } \\
\text { tions }\end{array}$ & $\begin{array}{l}\text { percentage of eligible patients with: dental } \\
\text { check, ocular pressure check, FOBT, flu vacc, } \\
\text { pneumo vacc, tetanus vacc, mammography, } \\
\text { pap smear (8) }\end{array}$ & $4.7 \%$ & $\begin{array}{l}5.8 \%(3.0 \% \text { to } \\
10.2 \%)\end{array}$ \\
\hline Binstock 1997 & $\begin{array}{l}\text { percentage of eligi- } \\
\text { ble patients with pap } \\
\text { smear }\end{array}$ & & $7.6 \%$ & \\
\hline Burack 1996_1 & $\begin{array}{l}\text { percentage of eligible } \\
\text { patients with mam- } \\
\text { mography }\end{array}$ & & $6.0 \%$ & \\
\hline Burack 1996_2 & $\begin{array}{l}\text { percentage of eligible } \\
\text { patients with mam- } \\
\text { mography }\end{array}$ & & $4.0 \%$ & \\
\hline Burack 1998_1 & $\begin{array}{l}\text { percentage of eligi- } \\
\text { ble patients with pap } \\
\text { smear }\end{array}$ & & $1.0 \%$ & \\
\hline Burack 1998_2 & $\begin{array}{l}\text { percentage of eligi- } \\
\text { ble patients with pap } \\
\text { smear }\end{array}$ & & $3.0 \%$ & \\
\hline
\end{tabular}


Table 1. Improvement rates of quality of care, by study (Continued)

\begin{tabular}{llc} 
Chambers 1989 & $\begin{array}{l}\text { percentage of eligible } \\
\text { patients with mam- } \\
\text { mography }\end{array}$ & $7.1 \%$ \\
\hline Chambers 1991 & $\begin{array}{l}\text { percentage of eligible } \\
\text { patients with flu vacc }\end{array}$ & $20.7 \%$
\end{tabular}

\begin{tabular}{lll}
\hline Dexter 1998 & $\begin{array}{l}\text { percentage of eligible patients with: discus- } \\
\text { sion of directives, completion of directives (2) }\end{array}$ & $\begin{array}{l}9.2 \%(6.1 \% \text { to } \\
12.3 \%)\end{array}$ \\
\hline Gilutz 2009 & $\begin{array}{l}\text { percentage of patients with adequate mon- } \\
\text { itoring, percentage of eligible patients with } \\
\text { initiation or up-titration of statin therapy, per- } \\
\text { centage of eligible patients with up-titration } \\
\text { (3) }\end{array}$ & $\begin{array}{l}5.4 \%(1.2 \% \text { to } \\
6.1 \%)\end{array}$ \\
\end{tabular}

\begin{tabular}{|c|c|c|c|c|}
\hline $\begin{array}{l}\text { Heidenreich } \\
2005\end{array}$ & $\begin{array}{l}\text { percentage of eligible } \\
\text { patients with ACE in- } \\
\text { hibitor prescription }\end{array}$ & & $11.5 \%$ & \\
\hline $\begin{array}{l}\text { Heidenreich } \\
2007\end{array}$ & $\begin{array}{l}\text { percentage of eligible } \\
\text { patients with any } \beta \text { - } \\
\text { blocker prescription }\end{array}$ & $\begin{array}{l}\text { percentage of eligible patients with recom- } \\
\text { mended } \beta \text {-blocker prescription }\end{array}$ & $7.9 \%$ & $\begin{array}{l}6.7 \%(5.4 \% \text { to } \\
7.9 \%)\end{array}$ \\
\hline Heiman 2004 & $\begin{array}{l}\text { percentage of eligible } \\
\text { patients with advance } \\
\text { directives }\end{array}$ & $\begin{array}{l}\text { percentage of eligible patients with: discus- } \\
\text { sion or completion of directives, completion } \\
\text { of healthcare proxy, completion of living will } \\
\text { (3) }\end{array}$ & $-0.2 \%$ & $\begin{array}{l}-0.3 \%(-0.9 \% \text { to } \\
-0.2 \%)\end{array}$ \\
\hline Javitt 2005 & $\begin{array}{l}\text { compliance rate } \\
\text { with prescription re- } \\
\text { minders (start a new } \\
\text { drug) (denominator: } \\
\text { reminders) }\end{array}$ & & $7.0 \%$ & \\
\hline Le Breton 2016 & $\begin{array}{l}\text { adherence to colorec- } \\
\text { tal cancer screening }\end{array}$ & & $1.7 \%$ & \\
\hline Lobach 1997 & $\begin{array}{l}\text { overall physician com- } \\
\text { pliance rate }\end{array}$ & $\begin{array}{l}\text { physician compliance rate with: foot exam, } \\
\text { physical exam, glycated hemoglobin, urine } \\
\text { protein determination, cholesterol level, eye } \\
\text { exam, flu vacc, pneumo vacc (8) }\end{array}$ & $16.4 \%$ & $\begin{array}{l}22.7 \%(11.0 \% \text { to } \\
28.4 \%)\end{array}$ \\
\hline Majumdar 2007 & $\begin{array}{l}\text { overall compliance } \\
\text { rate with prescription } \\
\text { reminders }\end{array}$ & $\begin{array}{l}\text { percentage of eligible patients with: ACE in- } \\
\text { hibitor or ARB therapy prescription, statins } \\
\text { prescription }\end{array}$ & $6.0 \%$ & $\begin{array}{l}9.0 \%(0.0 \% \text { to } \\
18.0 \%)\end{array}$ \\
\hline Mazzuca 1990 & & $\begin{array}{l}\text { physician compliance rate with: glycated he- } \\
\text { moglobin, fasting blood glucose, home-mon- } \\
\text { itored blood glucose, diet clinic referral, oral } \\
\text { hypoglycemic agents (5) }\end{array}$ & & $\begin{array}{l}4.0 \%(4.0 \% \text { to } \\
5.0 \%)\end{array}$ \\
\hline McAlister 2009 & $\begin{array}{l}\text { overall compliance } \\
\text { rate with prescription } \\
\text { reminders }\end{array}$ & $\begin{array}{l}\text { percentage of eligible patients with: statins, } \\
\text { standardized statin dose, another lipid-low- } \\
\text { ering drug, acetylsalicylic acid, acetylsalicylic } \\
\text { acid or thienopyridine, ACE inhibitor, ACE in- } \\
\text { hibitor or ARB, } \beta \text {-blocker, triple therapy (8) }\end{array}$ & $6.6 \%$ & $\begin{array}{l}0.5 \%(-0.4 \% \text { to } \\
2.2 \%)\end{array}$ \\
\hline
\end{tabular}


Table 1. Improvement rates of quality of care, by study (Continued)

\begin{tabular}{cllll} 
McDonald 1976a & $\begin{array}{l}\text { overall compliance } \\
\text { rate with prescription } \\
\text { reminders (denomina- } \\
\text { tor: reminders) }\end{array}$ & $\begin{array}{l}\text { compliance with: observing a physical finding } \\
\text { or inquiring about a symptom, ordering a di- } \\
\text { agnostic study, changing or initiating a thera- } \\
\text { peutic regimen (3) }\end{array}$ & $\begin{array}{l}28.9 \% \\
24.7 \%(21.1 \% \text { to } \\
38.8 \%)\end{array}$ \\
\hline McDonald 1976b & $\begin{array}{l}\text { overall compliance } \\
\text { rate with reminders } \\
\text { (denominator: re- }\end{array}$ & $\begin{array}{l}\text { percentage of patients with: test order, thera- } \\
\text { peutic change (2) }\end{array}$ & $23.5 \%$ & $\begin{array}{l}20.3 \%(14.9 \% \text { to } \\
25.7 \%)\end{array}$ \\
\hline
\end{tabular}

\begin{tabular}{ll}
\hline McDonald 1980 & $\begin{array}{l}\text { overall compliance } \\
\text { rate with reminders } \\
\text { (denominator: re- } \\
\text { minders) }\end{array}$ \\
\hline
\end{tabular}

\section{McDonald 1984 overall compliance} rate with reminders

\author{
$\begin{array}{ll}\begin{array}{l}\text { percentage of patients with: FOBT, pap smear, } \\ \text { chest roentgenogram, pneumo vacc, tuber- }\end{array} & \begin{array}{l}13.0 \% \text { (10.5\% to } \\ 24.5 \%)\end{array}\end{array}$ \\ culosis skin test, serum potassium, mam- \\ mogram, flu vacc, diet, digitalis, antacids, $\beta$ - \\ blockers (12)
}

\begin{tabular}{lll}
\hline McPhee 1989_1 & $\begin{array}{l}\text { physician compliance rate with: FOBT, rectal } \\
\text { exam, sigmoidoscopy, pap smear, pelvic ex- } \\
\text { am, breast exam, mammography (7) }\end{array}$ & $\begin{array}{l}23.0 \%(20.0 \% \text { to } \\
33.0 \%)\end{array}$ \\
\hline McPhee 1989_2 & $\begin{array}{l}\text { physician compliance rate with: breast exam, } \\
\text { mammography (2) }\end{array}$ & $\begin{array}{l}23.2 \%(20.0 \% \text { to } \\
26.5 \%)\end{array}$ \\
\hline Morgan 1978 & $\begin{array}{l}\text { percentage of patients with: blood group and } \\
\text { type, syphilis serology, prenatal counseling, } \\
\text { pregnancy diet counseling, sickle cell prepa- } \\
\text { ration (5) }\end{array}$ & $0.1 \%(-1.9 \%$ to \\
$2.0 \%)$
\end{tabular}

\begin{tabular}{|c|c|c|c|c|}
\hline Ornstein 1991_1 & & $\begin{array}{l}\text { percentage of eligible patients with: FOBT, } \\
\text { mammography, tetanus vacc, cholesterol, } \\
\text { pap smear (5) }\end{array}$ & & $\begin{array}{l}4.4 \%(3.9 \% \text { to } \\
6.9 \%)\end{array}$ \\
\hline Ornstein 1991_2 & & $\begin{array}{l}\text { percentage of eligible patients with: FOBT, } \\
\text { mammography, tetanus vacc, cholesterol, } \\
\text { pap smear (5) }\end{array}$ & & $\begin{array}{l}6.1 \%(3.9 \% \text { to } \\
7.0 \%)\end{array}$ \\
\hline Rosser 1991 & $\begin{array}{l}\text { overall compliance } \\
\text { rate }\end{array}$ & $\begin{array}{l}\text { percentage of eligible patients with: flu vacc, } \\
\text { tetanus vacc, BP reading, pap smear ( } 4 \text { ) }\end{array}$ & $19.2 \%$ & $\begin{array}{l}11.4 \%(6.0 \% \text { to } \\
16.4 \%)\end{array}$ \\
\hline Rossi 1997 & $\begin{array}{l}\text { percentage of eligible } \\
\text { patients with prescrip- } \\
\text { tion change }\end{array}$ & & $11.0 \%$ & \\
\hline Thomas 1983 & $\begin{array}{l}\text { compliance rate with } \\
\text { reminders }\end{array}$ & & $12.9 \%$ & \\
\hline Tierney 1986_1 & & $\begin{array}{l}\text { physician compliance rate with: FOBT, pneu- } \\
\text { mo vacc, antacids, TB skin testing, } \beta \text {-blockers, } \\
\text { nitrates, anti-depressants, calcium supple- }\end{array}$ & & $\begin{array}{l}1.5 \%(0.5 \% \text { to } \\
11.0 \%)\end{array}$ \\
\hline
\end{tabular}


Table 1. Improvement rates of quality of care, by study (Continued)

ments, pap smear, mammography, metron-

idazole, digitalis, salicylates (13)

\begin{tabular}{|c|c|c|c|c|}
\hline Tierney 1986_2 & & $\begin{array}{l}\text { physician compliance rate with: FOBT, pneu- } \\
\text { mo vacc, antacids, TB skin testing, } \beta \text {-blockers, } \\
\text { nitrates, anti-depressants, calcium supple- } \\
\text { ments, pap smear, mammography, metron- } \\
\text { idazole, digitalis, salicylates (13) }\end{array}$ & & $\begin{array}{l}1.0 \%(-0.5 \% \text { to } \\
2.0 \%)\end{array}$ \\
\hline Turner 1989 & & $\begin{array}{l}\text { physician compliance rate with: FOBT, rectal } \\
\text { exam, pap smear, breast exam, mammogra- } \\
\text { phy (5) }\end{array}$ & & $\begin{array}{l}3.6 \%(-5.8 \% \text { to } \\
10.1 \%)\end{array}$ \\
\hline Were 2013 & $\begin{array}{l}\text { completion of overdue } \\
\text { clinical tasks (denomi- } \\
\text { nator: reminders) }\end{array}$ & $\begin{array}{l}\text { completion of overdue clinical task for: or- } \\
\text { dering chest x-ray, ordering 18-mo human } \\
\text { immunodeficiency virus enzyme-linked im- } \\
\text { munosorbent assay, ordering other laborato- } \\
\text { ry tests, beginning antiretroviral therapy, re- } \\
\text { ferring to nutritional support (5) }\end{array}$ & $50.0 \%$ & $\begin{array}{l}39.0 \%(26.0 \% \text { to } \\
54.0 \%)\end{array}$ \\
\hline White 1984 & $\begin{array}{l}\text { compliance rate with } \\
\text { reminders (denomina- } \\
\text { tor: reminders) }\end{array}$ & & $12.0 \%$ & \\
\hline Ziemer 2006_1 & $\begin{array}{l}\text { physician compliance } \\
\text { rate }\end{array}$ & & $0.2 \%$ & \\
\hline Ziemer 2006_2 & $\begin{array}{l}\text { physician compliance } \\
\text { rate }\end{array}$ & & $0.7 \%$ & \\
\hline
\end{tabular}

ACE: angiotensin-converting enzyme, ARB: angiotensin II receptor blockers, BP: blood pressure, flu: influenza, FOBT: fecal occult blood test, pneumo: pneumococcal, TB: tuberculosis, Vacc: vaccination

Table 2. Median improvement of quality of care across all comparisons and according to the presence of cointerventions

\begin{tabular}{llll}
\hline & Median improvement (interquartile range) & \\
& $\begin{array}{l}\text { Using primary (or median) out- } \\
\text { come }\end{array}$ & Using largest outcome & Using smallest outcome \\
\hline All $(\mathrm{n}=40)$ & $6.8 \%$ & $12.0 \%$ & $4.0 \%$ \\
& $(3.8 \%$ to $17.5 \%)$ & $(6.1 \%$ to $20.2 \%)$ & $(0.5 \%$ to $11.3 \%)$ \\
\hline Reminders alone $(\mathrm{n}=27)$ & $11.0 \%$ & $12.3 \%$ & $6.1 \%$ \\
& $(5.4 \%$ to $20.0 \%)$ & $(7.0 \%$ to $33.5 \%)$ & $(1.2 \%$ to $12.9 \%)$ \\
\hline $\begin{array}{l}\text { Reminders with co-inter- } \\
\text { vention }(\mathrm{s})(\mathrm{n}=13)\end{array}$ & $4.0 \%$ & $9.8 \%$ & $0.7 \%$ \\
& $(3.0 \%$ to $6.0 \%)$ & $(3.9 \%$ to $12.5 \%)$ & $(-1.9 \%$ to $3.6 \%)$ \\
\hline
\end{tabular}


Table 3. Improvement of patient outcomes, by study

\begin{tabular}{|c|c|c|}
\hline Study ID & Patient outcome: percentage difference between groups at follow-up & $\begin{array}{l}\text { Patient outcome: mean } \\
\text { difference between } \\
\text { groups at follow-up }\end{array}$ \\
\hline Barnett 1983 & $\begin{array}{l}\text { Percentage of patients with } \mathrm{BP}<100 \text { or receiving treatment at } 12 \text { mo: } \\
18.1 \%\end{array}$ & \\
\hline Gilutz 2009 & Event-free survival: $-2.1 \%$ & LDL level: $-2.4 \mathrm{mg} / \mathrm{dL}$ \\
\hline Heidenreich 2005 & Mortality: hazard ratio: 0.98 (95\% Cl: 0.78 to 1.23 ) & $\begin{array}{l}\text { Diastolic BP: } 0 \\
\text { Systolic BP: } 0\end{array}$ \\
\hline McAlister 2009 & Mortality: $1 \%$ & \\
\hline Rossi 1997 & & $\begin{array}{l}\text { Diastolic BP: }-4 \\
\text { Systolic BP: } 0\end{array}$ \\
\hline Ziemer $2006 \_1$ & $\begin{array}{l}\text { Percentage of patients with Hbalc<7.0\%: OR: } 0.98 \text { ( } 95 \% \mathrm{Cl}: 0.86 \text { to } 1.12) \\
\text { Percentage of patients with systolic BP<130: OR: } 1.04 \text { ( } 95 \% \text { Cl: } 0.94 \text { to } 1.16) \\
\text { Percentage of patients with LDL<100: OR } 0.92 \text { ( } 95 \% \text { Cl: } 0.79 \text { to } 1.08)\end{array}$ & $\begin{array}{l}\text { Hba1c: } 0.1 \\
\text { Systolic BP: }-1.2 \\
\text { LDL level: } 2.5 \mathrm{mg} / \mathrm{dL}\end{array}$ \\
\hline Ziemer $2006 \_\mathbf{2}$ & $\begin{array}{l}\text { Percentage of patients with } \mathrm{Hba} 1 \mathrm{c}<7.0 \%: \text { OR: } 0.99 \text { ( } 95 \% \mathrm{Cl} \text { : } 0.82 \text { to } 1.19) \\
\text { Percentage of patients with systolic BP<130: OR: } 0.92 \text { ( } 95 \% \mathrm{Cl}: 0.79 \text { to } 1.06) \\
\text { Percentage of patients with LDL<100: OR } 1.05 \text { ( } 95 \% \mathrm{Cl}: 0.84 \text { to } 1.31 \text { ) }\end{array}$ & $\begin{array}{l}\text { Hba1c: } 0.4 \\
\text { Systolic BP: } 0.8 \\
\text { LDL level: } 3.0 \mathrm{mg} / \mathrm{dL}\end{array}$ \\
\hline
\end{tabular}

BP: blood pressure, Hba1c: glycated hemoglobin, LDL: low-density lipoprotein, mo: months

\section{APPENDICES}

Appendix 1. Update search strategies MEDLINE (OVID)

Epub Ahead of Print, In-Process \& Other Non-Indexed Citations, Ovid MEDLINE(R) Daily and Ovid MEDLINE(R) 1946 to Present

\begin{tabular}{|c|c|c|}
\hline No. & Search terms & Results \\
\hline 1 & $\begin{array}{l}\text { reminder systems/ or computer*.mp. or decision support systems, clinical/ } \\
\text { or physician's practice patterns/or "forms and records control"/ or exp hospi- } \\
\text { tal information systems/or exp artificial intelligence/ or exp decision making, } \\
\text { computer-assisted/ or "appointments and schedules"/ or exp medical records/ } \\
\text { or exp clinical protocols/ }\end{array}$ & 1036105 \\
\hline 2 & 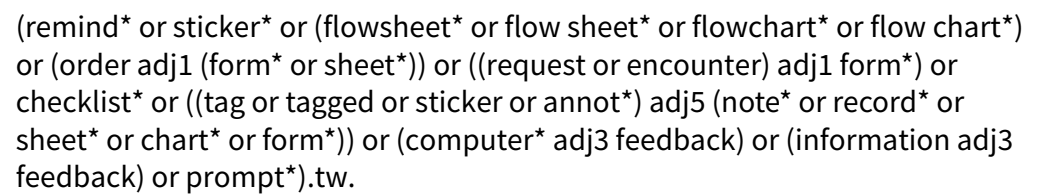 & 155205 \\
\hline
\end{tabular}




\begin{tabular}{|c|c|}
\hline 4 & exp animals/ not humans.sh. \\
\hline 5 & 3 not 4 \\
\hline 6 & 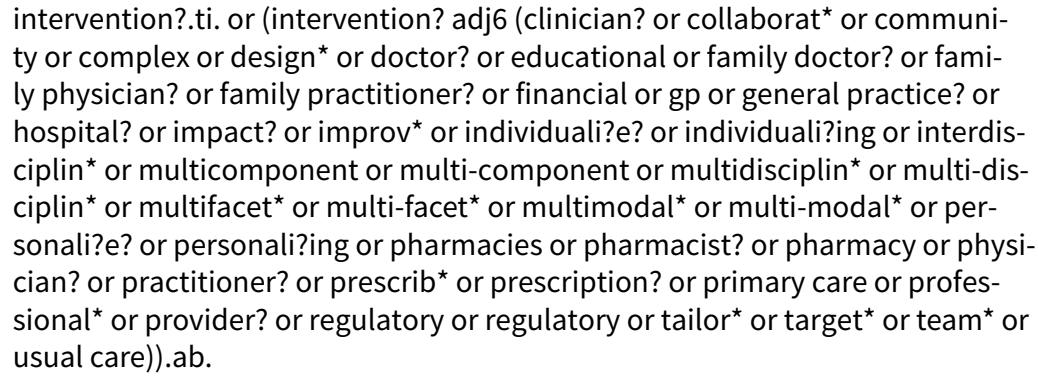 \\
\hline
\end{tabular}

4319541

1013244

220471

(pre-intervention? or preintervention? or "pre intervention?" or post-interven-
tion? or postintervention? or "post intervention?").ti,ab.

8
tion? or postintervention? or "post intervention?").ti,ab. tioner? or provider? or physician? or nurse? or nursing or doctor?).ti,hw.

\begin{tabular}{|c|c|c|}
\hline 9 & demonstration project?.ti,ab. & 2226 \\
\hline 10 & $\begin{array}{l}\text { (pre-post or "pre test }{ }^{\star} " \text { or pretest }{ }^{\star} \text { or posttest }^{\star} \text { or }_{\text {post test }}{ }^{\star} \text { or (pre adj5 } \\
\text { post)).ti,ab. }\end{array}$ & 87464 \\
\hline 11 & $\begin{array}{l}\text { (pre-workshop or post-workshop or (before adj3 workshop) or (after adj3 } \\
\text { workshop)).ti,ab. }\end{array}$ & 825 \\
\hline 12 & trial.ti. or ((study adj3 aim?) or "our study").ab. & 848755 \\
\hline 13 & (before adj10 (after or during)).ti,ab. & 417939 \\
\hline 14 & $\begin{array}{l}\text { ("quasi-experiment*" or quasiexperiment* or "quasi random*" or quasiran- } \\
\text { dom }^{\star} \text { or "quasi control*" or quasicontrol }{ }^{\star} \text { or ((quasi* or experimental) adj3 } \\
\left.\left(\text { method }^{\star} \text { or study or trial or design }{ }^{\star}\right)\right) \text { ).ti,ab,hw. }\end{array}$ & 124707 \\
\hline 15 & ("time series" adj2 interrupt").ti,ab,hw. & 1751 \\
\hline 16 & $\begin{array}{l}\text { (time points adj3 (over or multiple or three or four or five or six or seven or } \\
\text { eight or nine or ten or eleven or twelve or month^ or hour? or day? or "more } \\
\text { than")).ab. }\end{array}$ & 12834 \\
\hline 17 & pilot.ti. & 52038 \\
\hline 18 & pilot projects/ & 97260 \\
\hline 19 & (clinical trial or controlled clinical trial or multicenter study).pt. & 684859 \\
\hline 20 & (multicentre or multicenter or multi-centre or multi-center).ti. & 37868 \\
\hline 21 & random*.ti,ab. or controlled.ti. & 940170 \\
\hline
\end{tabular}


(Continued)

22

(control adj3 (area or cohort? or compare? or condition or design or group? or intervention? or participant? or study)).ab. not (controlled clinical trial or randomized controlled trial).pt.

\begin{tabular}{lll}
\hline 23 & $\begin{array}{l}\text { (control year? or experimental year? or (control period? or experimental peri- } \\
\text { od?).ti,ab. }\end{array}$ & 15070 \\
\hline 24 & evaluation studies as topic/ or prospective studies/ or retrospective studies/ & 1135413 \\
\hline 25 & (utili?ation or programme or programmes).ti. & 64750 \\
\hline 26 & (during adj5 period).ti,ab. & 347377 \\
\hline 27 & ((strategy or strategies) adj2 (improv* or education*)).ti,ab. & 25348 \\
\hline 28 & (purpose adj3 study).ab. & 341494 \\
\hline 29 & $\begin{array}{l}\text { "comment on".cm. or review.pt. or (review not "peer review*").ti. or random- } \\
\text { ized controlled trial.pt. }\end{array}$ & 6113916 \\
\hline 30 & $\begin{array}{l}\text { (rat or rats or cow or cows or chicken? or horse or horses or mice or mouse or } \\
\text { bovine or animal?).ti,hw. or veterinar*.ti,ab,hw. }\end{array}$ & 4319541 \\
\hline 31 & exp animals/ not humans.sh. & 3429439 \\
\hline 32 & \begin{tabular}{l} 
(or/6-28) not (or/29-31) \\
\hline 32
\end{tabular} & 6104 \\
\hline
\end{tabular}

\section{Embase (OVID)}

Embase 1974 to 2016 September 21

\begin{tabular}{|c|c|}
\hline No. & Search terms \\
\hline 1 & 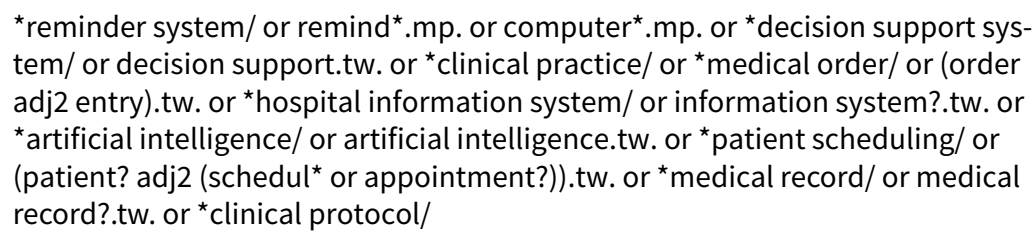 \\
\hline 2 & 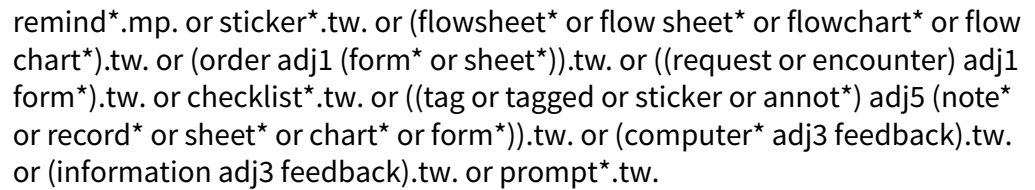 \\
\hline
\end{tabular}

Results

1628912

205015

\section{5}

\begin{tabular}{|c|c|}
\hline 3 & 1 and 2 \\
\hline 4 & $\begin{array}{l}\text { ((education* adj2 (program }{ }^{\star} \text { or intervention? or meeting? or session? or } \\
\text { strateg* or workshop? or visit?)) or (behavio? }{ }^{\star} \text { adj2 intervention?) or (leaflet? } \\
\text { or booklet? or poster or posters) or ((written or printed or oral) adj informa- } \\
\text { tion) or (information }{ }^{\star} \text { adj2 campaign) or (education }{ }^{\star} \text { adj1 (method? or mater- }\end{array}$ \\
\hline
\end{tabular}

Computer-generated reminders delivered on paper to healthcare professionals: effects on professional practice and healthcare outcomes 83 (Review)

Copyright $\odot 2017$ The Cochrane Collaboration. Published by John Wiley \& Sons, Ltd. 
ial?)) or outreach or ((opinion or education* or influential) adj1 leader?) or facilitator? or academic detailing or consensus conference? or practice guideline? or (guideline? adj2 (introduc* or issu* or impact or effect? or disseminat ${ }^{\star}$ or distribut $\left.{ }^{\star}\right)$ ) or ((introduc* or impact or effect? or implement* ${ }^{\star}$ or computer ${ }^{\star}$ or compli*) adj2 protocol?) or ((introduc ${ }^{\star}$ or impact or effect? or implement* or computer* or compli*) adj2 algorithm?) or clinical pathway? or critical pathway? or ((effect? or impact or evaluat ${ }^{\star}$ or introduc ${ }^{\star}$ or compar ${ }^{\star}$ ) adj2 training program ${ }^{\star}$ ) or reminder? or (recall adj2 system ${ }^{\star}$ ) or (prompter? or prompting) or advance directive?).tw. or ${ }^{\star}$ feedback/ or feedback.tw. or chart review*.tw. or ((effect? or impact or records or chart?) adj2 audit).tw. or compliance.tw. or marketing.tw. or ((cost or clinical or medical) adj information).tw. or * medical education/ or * medical audit/ or * continuing education/ or * postgraduate education/ (fee for service or cost shar* or (copayment? or co payment?) or (prepay* or prepaid or prospective payment?) or formular? or fundhold? or blue cross or voucher? or (free adj2 care)).tw. or exp *health insurance/ or *health care costs/ or *health care financing/ or *medical fee/ or * prospective payment/ medic?).tw. or exp *paramedical personnel/ or * general practitioner/ or *physician/ or (team? adj2 (care or treatment or assessment or consultation)).tw. or (integrat* adj2 (care or service?)).tw. or (care adj2 (coordinat* or program* or continuity)).tw. or (case adj1 management).tw. or * patient care/ or (chang* adj1 location?).tw. or domiciliary.tw. or (home adj1 (treat* or visit?)).tw. or day surgery.tw. or exp * primary health care/ or *ambulatory surgery/ or *nursing home/ or *day hospital/ or *outpatient care/ or *terminal care/ or * group practice/ or * general practice/ or * ${ }^{\star}$ ural health care/ or * $c 0 m$ munity mental health center/ or *information system/ or * medical record/ or (information adj2 (management or system?)).tw. or * peer review/ or * professional standards review organization/ or exp * clinical practice/ or quality assurance.tw. or exp *health care delivery/ or *health care quality/ or * professional practice/ or (early adj1 discharg*).tw. or discharge planning.tw. or offset.tw. or triage.tw. or near patient testing.tw. or * patient referral/ or (physician patient adj (interaction? or relationship?)).tw. or managed care.tw. or *health care organization/ or *health maintenance organization/ or *health care system/ or *health care access/ or (hospital? adj1 merg*).tw. or (comput$\mathrm{er}^{\star}$ adj2 (dosage or dosing or diagnosis therapy or decision?)).tw. or (computer ${ }^{\star}$ adj2 (diagnosis or therapy)).tw. or gatekeep*.tw. tern) adj2 care) or (program ${ }^{\star}$ adj2 (reduc* or increas* or decreas ${ }^{\star}$ or chang ${ }^{\star}$ or improv* or modify* or monitor ${ }^{\star}$ or care)) or (program* adj1 (health or care or intervention?)) or ((effect or impact or introduc*) adj2 (legislation or regulations or policy)) or ((effect? or impact or evaluat* or introduc ${ }^{\star}$ or compar $\left.{ }^{\star}\right)$ adj2 treatment program*) or ((effect? or impact or evaluat* or introduc* or compar $^{\star}$ ) adj2 care program $\left.{ }^{\star}\right)$ or ((effect? or impact or evaluat ${ }^{\star}$ or introduc ${ }^{\star}$ or compar $^{\star}$ ) adj2 screening program $\left.{ }^{\star}\right)$ or ((effect? or impact or evaluat* or introduc $^{\star}$ or compar ${ }^{\star}$ ) adj2 prevent $^{\star}$ program $\left.\left.^{\star}\right)\right)$.tw.

\begin{tabular}{ll}
\hline 8 & or 5 or 6 or 7 \\
\hline 9 & $\begin{array}{l}\text { (computer } \text { or electronic }^{*} \text { or print or printed or print-out* or paper or pa- } \\
\text { per-based).ti,ab. }\end{array}$ \\
\hline 10 & $\begin{array}{l}\text { randomized controlled trial/ or (randomised or randomized).tw. or experimen- } \\
\mathrm{t}^{\star} . \mathrm{tw} \text {. or (time adj series).tw. or (pre test or pretest or posttest or post test).tw. }\end{array}$
\end{tabular}




\begin{tabular}{llc}
\hline 11 & $\begin{array}{l}\text { (random sampl* or random digit* or random effect* or random survey or ran- } \\
\text { dom regression).ti,ab. not randomized controlled trial/ [per bmj clinical evi- } \\
\text { dence filter] }\end{array}$ & 74330 \\
\hline 12 & $\begin{array}{l}\text { (exp animals/ or exp invertebrate/ or animal experiment/ or animal model/ or } \\
\text { animal tissue/ or animal cell/ or nonhuman/) and (human/ or normal human/ } \\
\text { or human cell/) }\end{array}$ & 17977645 \\
\hline 13 & $\begin{array}{l}\text { (exp animals/ or exp invertebrate/ or animal experiment/ or animal model/ or } \\
\text { animal tissue/ or animal cell/ or nonhuman/) not } 12\end{array}$ & 5840407 \\
\hline 14 & 10 not (or/11,13) & 10163810 \\
\hline 15 & 3 and 8 and 9 and 14 & 4430 \\
\hline
\end{tabular}

\section{Cochrane Library (Wiley)}

\begin{tabular}{lll}
\hline No. & Search terms & Results \\
\hline$\# 1$ & [mh "reminder systems"] & 749 \\
\hline$\# 2$ & (prompt? near/5 booklet? or prompt? near/5 chart? or prompt? near/5 check- & 15 \\
& list? or prompt? near/5 check-list? or prompt? near/5 display? or prompt? \\
& near/5 flowchart? or prompt? near/5 flow sheet? or prompt? near/5 flow- \\
& sheet? or prompt? near/5 form? or prompt? near/5 "hard copy" or prompt? \\
& near/5 "hard copies" or prompt? near/5 insert? or prompt? near/5 leaflet\$ or \\
& prompt? near/5 manual or prompt? near/5 mail\$ or prompt? near/5 pamphlet\$ \\
& or prompt? near/5 paper or prompt? near/5 paper-based or prompt? near/5 \\
& postal? or prompt? near/5 postcard? or prompt? near/5 post-card? prompt? \\
& near/5 poster? or prompt? near/5 print\$ or prompt? near/5 sheet? or prompt? \\
& near/5 written or prompt? near/5 handwritten):ti,ab,kw
\end{tabular}

\#3 (alert? near/3 chart? or alert? near/3 checklist? or alert? near/3 check-list? or alert? near/3 handwritten or alert? near/3 "hard copy" or alert? near/3 "hard copies" or alert? near/3 insert\$ or alert? near/3 leaflet $\$$ or alert? near/3 manual or alert? near/3 mail\$ or alert? near/3 pamphlet\$ or alert? near/3 paper or alert? near/3 paper-based or alert? near/3 postal? or alert? near/3 postcard? or alert? near/3 post-card? or alert? near/3 poster? or alert? near/3 print $\$$ or alert? near/3 sheet? or alert? near/3 written):ti,ab,kw

\begin{tabular}{|c|c|c|}
\hline$\# 4$ & (chart ${ }^{\star}$ near $/ 2$ insert $^{\star}$ or medical record ${ }^{\star}$ near $/ 2$ insert ${ }^{\star}$ ):ti,ab,kw & 6 \\
\hline \#5 & $\begin{array}{l}\text { (chart }{ }^{\star} \text { near } / 4 \text { stamp }^{\star} \text { or record }{ }^{\star} \text { near } / 4 \text { stamp* }^{\star} \text { or chart* near } / 4 \text { sticker }^{\star} \text { or } \\
\left.\text { record }^{\star} \text { near } / 4 \text { sticker }^{\star}\right): t i, a b, k w\end{array}$ & 19 \\
\hline \#6 & $\begin{array}{l}\text { (alert }{ }^{\star} \text { near/4 stamp* or alert* near/4 sticker }{ }^{\star} \text { or prompt }{ }^{\star} \text { near/4 stamp* or } \\
\text { prompt }^{\star} \text { near/4 sticker*):ti,ab,kw }\end{array}$ & 3 \\
\hline \#7 & $\begin{array}{l}\text { (alert }{ }^{\star} \text { near/4 stamp }{ }^{\star} \text { or alert }{ }^{\star} \text { near/4 sticker* } \text { or prompt }^{\star} \text { near } / 4 \text { stamp }^{\star} \text { or } \\
\left.\text { prompt }^{\star} \text { near/4 sticker }{ }^{\star}\right): t i, a b, k w\end{array}$ & 3 \\
\hline
\end{tabular}


(Continued)

\#8

(prompt* near/3 record ${ }^{\star}$ or prompt ${ }^{\star}$ near $/ 3$ chart ${ }^{\star}$ or prompt ${ }^{\star}$ near $/ 3$ progress note ${ }^{\star}$ or alert ${ }^{\star}$ near $/ 3$ record ${ }^{\star}$ or alert ${ }^{\star}$ near $/ 3$ chart ${ }^{\star}$ or alert ${ }^{\star}$ near $/ 3$ progress note $\left.{ }^{\star}\right): t i, a b, k w$
65

54

(prompt* next physician* or prompt* next provider* or prompt ${ }^{\star}$ next practitioner $^{\star}$ or alert ${ }^{\star}$ next physician ${ }^{\star}$ or alert ${ }^{\star}$ next provider ${ }^{\star}$ or alert ${ }^{\star}$ next practitioner $\left.^{\star}\right):$ ti,ab,kw

\begin{tabular}{|c|c|}
\hline$\# 10$ & 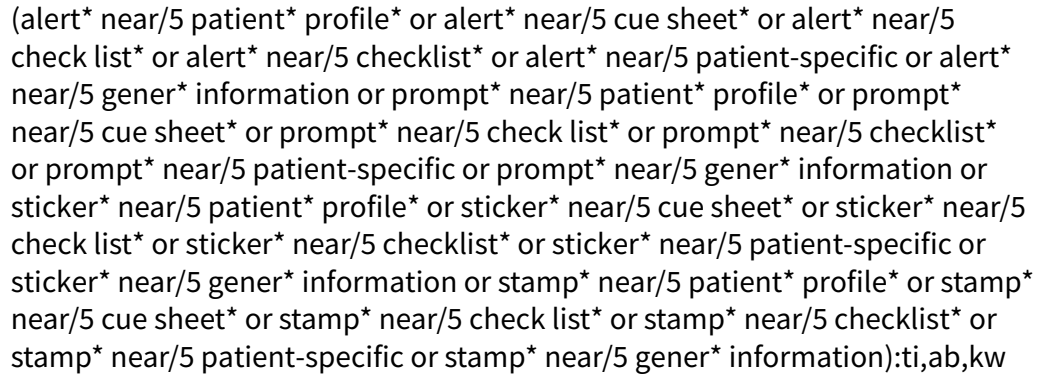 \\
\hline
\end{tabular}

\begin{tabular}{|c|c|c|}
\hline \#11 & $\left(\right.$ remind $\left.^{\star}\right): t i, a b, k w$ & 2466 \\
\hline \#12 & $\{$ or \#2-\#10\} & 239 \\
\hline \#13 & $\begin{array}{l}\text { (computer }{ }^{\star} \text { or electronic }{ }^{\star} \text { or print or printed or print-out }{ }^{\star} \text { or paper or pa- } \\
\text { per-based):ti,ab,kw }\end{array}$ & 45815 \\
\hline \#14 & [mh "medical records systems, computerized"] & 521 \\
\hline \#15 & [mh computers] & 1194 \\
\hline \#16 & $\{$ or \#13-\#15\} & 45974 \\
\hline \#17 & (\#1 or \#12) and \#16 & 360 \\
\hline \#18 & (\#11 and \#13) & 716 \\
\hline \#19 & \#17 or \#18 & 775 \\
\hline
\end{tabular}

\section{CINAHL (Ebsco)}

\begin{tabular}{lll}
\hline No. & Search terms & Results \\
\hline S1 & (MH "Reminder Systems") & 1,483 \\
\hline S2 & MH Decision Support Systems, Clinical & 1,759 \\
\hline S3 & (MH "Hospital Information Systems") & 1,908 \\
\hline S4 & (MH "Artificial Intelligence+") & 5,003 \\
\hline S5 & (MH "Decision Making, Computer Assisted+") & 11,706 \\
\hline S6 & (MH "appointments and schedules") & 4,000 \\
\hline
\end{tabular}

Computer-generated reminders delivered on paper to healthcare professionals: effects on professional practice and healthcare outcomes 86 
(Continued)

S7 $\quad$ (MH "Medical Records+") $\quad 61,477$

S8

$\mathrm{AB}\left(\right.$ computer $^{\star}$ OR clinical protocol $^{\star}$ ) or TI ( computer $^{\star}$ OR clinical protocol $\left.^{\star}\right) \quad 82,586$ or MW ( computer ${ }^{\star}$ OR clinical protocol ${ }^{*}$ )

S9 $\begin{array}{ll}\mathrm{TI} \text { ( form }{ }^{\star} \mathrm{N} 3 \text { control OR record }{ }^{*} \mathrm{~N} 3 \text { control ) or AB ( form }{ }^{*} \mathrm{~N} 3 \text { control OR } & 1,580 \\ \text { record }^{*} \mathrm{~N} 3 \text { control) }\end{array}$
record $^{\star} \mathrm{N} 3$ control )

\begin{tabular}{|c|c|}
\hline S10 & 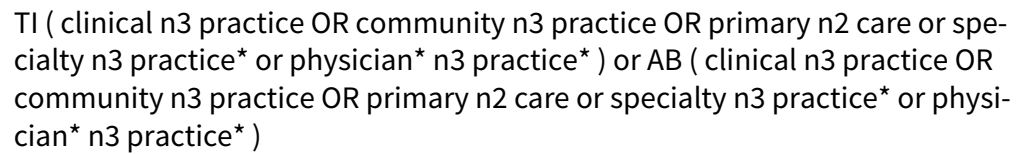 \\
\hline
\end{tabular}
cialty $n 3$ practice* or physician* $n 3$ practice ${ }^{\star}$

\begin{tabular}{|c|c|}
\hline $\mathrm{S} 12$ & 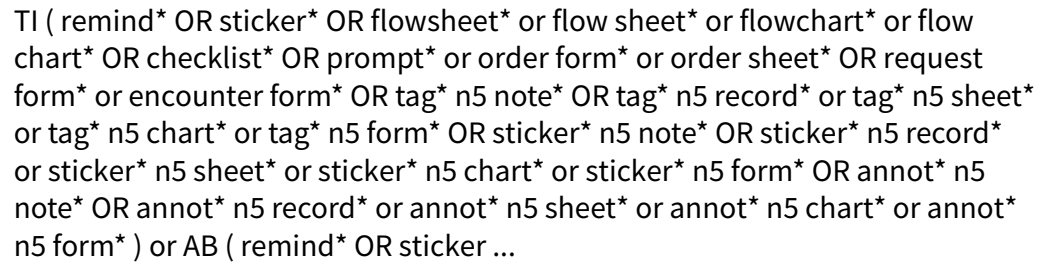 \\
\hline
\end{tabular}

S13 TI ( computer ${ }^{\star}$ n3 feedback OR information n3 feedback) or AB ( computer ${ }^{\star}$ n3 339
feedback OR information n3 feedback )

\begin{tabular}{|c|c|c|}
\hline S14 & (MH "Clinical Trials") & 85,055 \\
\hline S15 & (MH "random assignment") & 33,773 \\
\hline S16 & $\begin{array}{l}\mathrm{TI} \text { ( experiment }{ }^{\star} \text { or time series or pre-test or pretest or post-test or posttest or } \\
\text { Comparative Stud }{ }^{\star} \text { ) or } \mathrm{AB} \text { ( experiment* or time series or pre-test or pretest or } \\
\text { post-test or posttest or Comparative } \mathrm{Stud}^{\star} \text { ) }\end{array}$ & 61,170 \\
\hline S17 & (MH "Evaluation Research") & 22,078 \\
\hline S18 & $\begin{array}{l}\text { (MH "Experimental Studies") or (MH "Intervention Trials") or (MH "Triple-Blind } \\
\text { Studies") or (MH "Double-Blind Studies") or (MH "Single-Blind Studies") or (MH } \\
\text { "Solomon Four-Group Design") or (MH "Pretest-Posttest Design+") }\end{array}$ & 71,973 \\
\hline S19 & $\mathrm{S} 14$ or $\mathrm{S} 15$ or $\mathrm{S} 16$ or $\mathrm{S} 17$ or $\mathrm{S} 18$ & 224,649 \\
\hline S20 & $\mathrm{S} 1$ or $\mathrm{S} 2$ or $\mathrm{S} 3$ or $\mathrm{S} 4$ or $\mathrm{S} 5$ or $\mathrm{S} 6$ or $\mathrm{S} 7$ or $\mathrm{S} 8$ or $\mathrm{S} 9$ or $\mathrm{S} 10$ or $\mathrm{S} 11$ & 232,613 \\
\hline S21 & $\mathrm{S} 12$ or $\mathrm{S} 13$ & 7,469 \\
\hline S22 & S19 AND S20 AND S21 & 438 \\
\hline S23 & (MM "Reminder Systems") & 770 \\
\hline S24 & S19 and S23 & 213 \\
\hline S25 & $\mathrm{S} 22$ or S24 & 512 \\
\hline S26 & $\mathrm{S} 25$ & 102 \\
\hline
\end{tabular}




\section{INSPEC (Web of Science)}

1969-present

\begin{tabular}{lll}
\hline No. & Search terms & Results \\
\hline$\# 1$ & TS= ((reminder $\left.{ }^{\star}\right)$ AND $\left(\right.$ print $^{\star}$ OR paper $\left.)\right)$ & 896 \\
\hline$\# 2$ & $\# 1$ Indexes=Inspec Timespan=2015-2016 & 132 \\
\hline$\# 3$ & $\begin{array}{l}\text { Tl=(computer } \text { OR patient }^{\star} \text { OR physician* OR care OR clinic }{ }^{\star} \text { OR practice* OR } \\
\text { practitioner* OR trial* OR random* OR study OR studies) }\end{array}$ & $1,057,519$ \\
\hline$\# 4$ & \#3 AND \#2 & 16 \\
\hline
\end{tabular}

\section{WHAT'S NEW}

\begin{tabular}{lll}
\hline Date & Event & Description \\
\hline 16 August 2016 & $\begin{array}{l}\text { New citation required but conclusions } \\
\text { have not changed }\end{array}$ & Overall conclusions have not changed. \\
\hline 16 August 2016 & New search has been performed & $\begin{array}{l}\text { We searched for evidence to 21 September } 2016 \text { and included } \\
\text { three new studies. The review now has } 35 \text { studies. We have up- } \\
\text { dated the methods and other sections of the review in line with } \\
\text { current Cochrane and EPOC guidance }\end{array}$
\end{tabular}

\section{H I S T O R Y}

Protocol first published: Issue 3, 1998

Review first published: Issue 12, 2012

\begin{tabular}{lll}
\hline Date & Event & Description \\
\hline 18 July 2012 & Amended & Review amended following first peer-review process. \\
\hline 26 May 2008 & Amended & Review stage \\
\hline 25 May 2008 & Amended & Converted to new review format. \\
\hline
\end{tabular}

\section{CONTRIBUTIONS OF AUTHORS}

CA led the update process. CA extracted and analyzed the updated data. CA amended the text of the review. BB reviewed the updated review. MR and PD read and commented on the final version.

\section{DECLARATIONS OF INTEREST}

Chantal Arditi: none known. 
Myriam Rège-Walther: none known.

Pierre Durieux: none known.

Bernard Burnand: none known.

\section{SOURCES OF SUPPORT}

\section{Internal sources}

- Health Services Research Unit, University of Aberdeen, UK.

- Centre Hospitalier Vaudois and University of Lausanne, Switzerland.

\section{External sources}

- Loterie Romande, Lausanne, Switzerland.

- Department of Community Medicine and Community Healthcare, Centre Hospitalier Universitaire Vaudois, Lausanne, Switzerland.

$$
\text { Research Grant }
$$

\section{DIFFERENCES BETWEEN PROTOCOL AND REVIEW}

The search strategies were revised and updated by Paul Miller, the Information Specialist at EPOC. Text sections of the review were updated to reflect the latest Cochrane and EPOC guidance for conducting and reporting reviews.(e.g. certainty of evidence).

We changed the wording of the outcomes: instead of 'process adherence outcomes', we now use 'quality of care outcomes', and instead of 'clinical outcomes', we now use 'patient outcomes', in line with EPOC guidelines (EPOC 2015d). We classified quality of care outcomes as primary outcomes and patient outcomes as secondary outcomes. We added adverse effects outcomes as secondary outcomes and added a subgroup analysis on disadvantaged populations.

\section{INDEX TERMS}

\section{Medical Subject Headings (MeSH)}

*Medical Records; *Outcome and Process Assessment, Health Care; *Practice Patterns, Physicians' [standards]; *Reminder Systems [classification] [standards]; Clinical Competence; Non-Randomized Controlled Trials as Topic [statistics \& numerical data]; Patient Compliance; Quality of Health Care; Randomized Controlled Trials as Topic [statistics \& numerical data]

\section{MeSH check words}

Humans 